H.M.

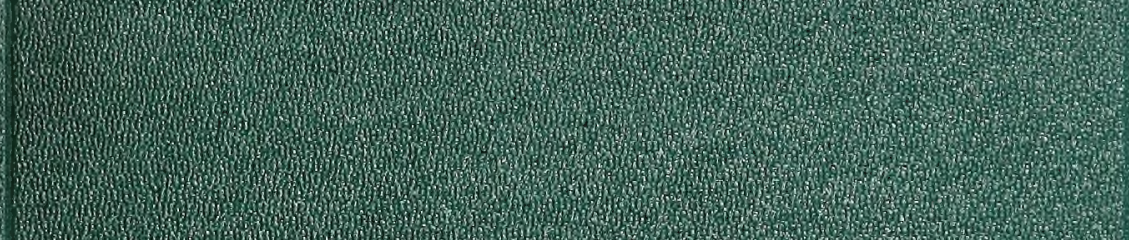

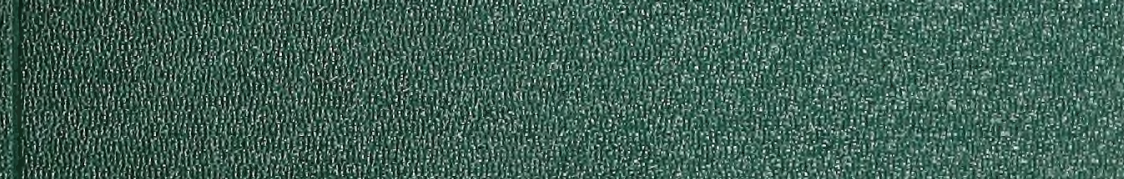
H.t.

1.

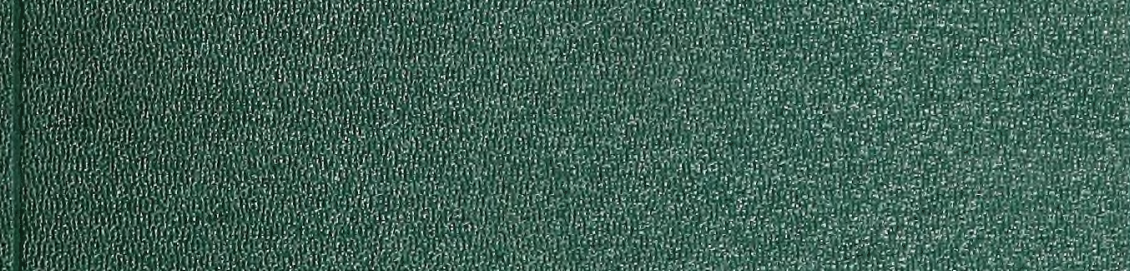

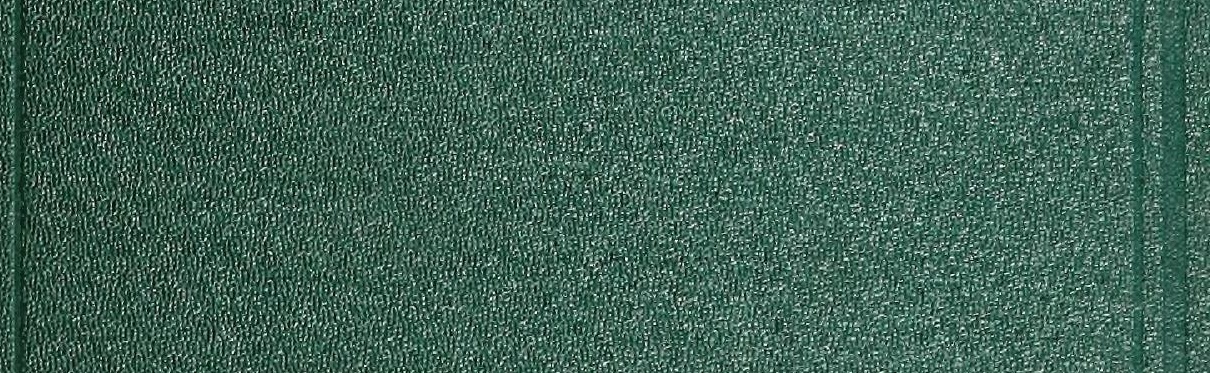

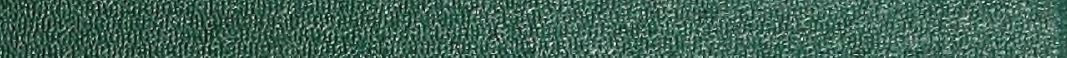
M.

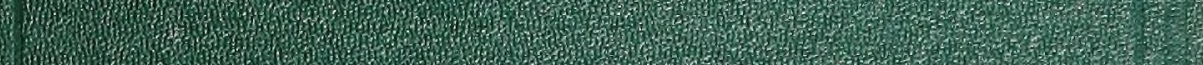




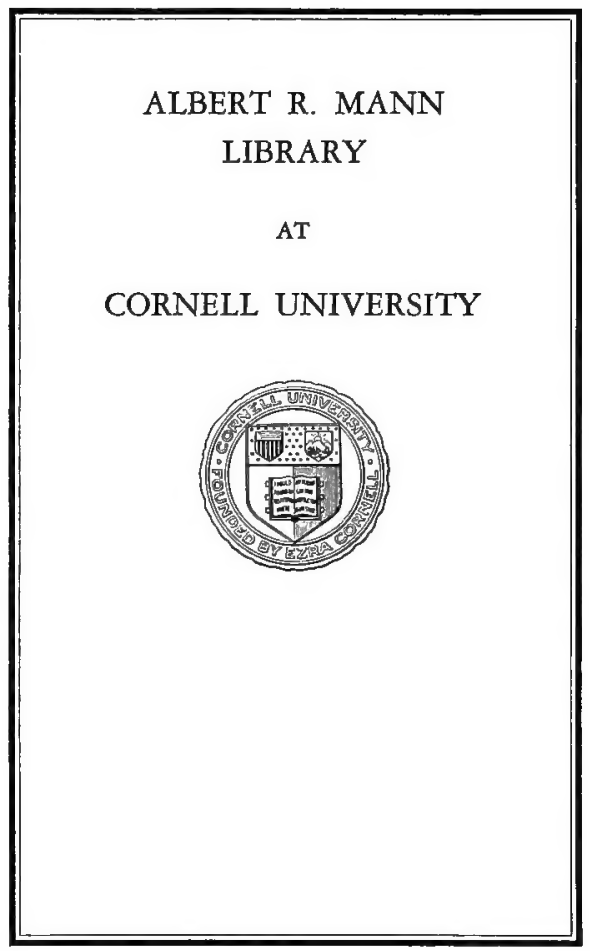




\section{Cornell University Library \\ QR 41.M192}

The Bacteria.

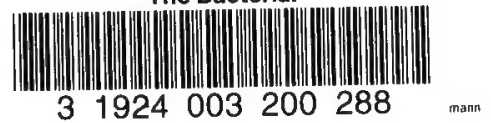




\section{Cornell University Library}

\section{The original of this book is in the Cornell University Library.}

There are no known copyright restrictions in the United States on the use of the text. 




\title{
THE BACTERIA.
}

$\mathbf{B Y}$

\section{DR. ANTOINE MAGNIN,}

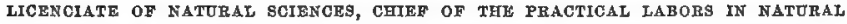
HISTORY TO THE FACDLTY OF MEDICINE OF LYONS, LAUREATE OF THE FACULTY

OF MEDICINE OF PARIS (SILVER MEDAL, 1876), GENRRAL SECRETARY

OF THI BOTANICAL SOGIETY OF LYONS, MEMBER OF THE BOTANIGAL SOCIETY OH BRANCE, ETO.
\end{abstract}

TRANSLATED BY

GEORGE M. STERNBERG, M.D., SURGLON U. S. ARMX.

B OSTON:

LITTLE, BROWN, AND COMPANY.

1880. 
Copyright, 1880,

Bt George M. Sternberg.

Untpresity Press:

Johy Witson and Son, Cambridge. 


\section{PREFACE BY TRANSLATOR.}

HAVING found the admirable resume of our knowledge of the bacteria, by Dr. Magnin, of great assistance to me, in pursuing the investigations in which $I$ have been engaged during the past year under the auspices of the National Board of Health, it has seemed to me that a translation of the work into English and its publication in this country would be productive of good in more ways than one, and of the advancement of science. To the naturalist, it cannot fail to be of value, as the most approved classification, that of Cohn, is given, with a full description of species. To give additional value to this portion of the work, figures of many of the best-known forms, drawn from various foreign sources, and reproductions of some of my own photo-micographs (by permission of the National Board of Health), have been introduced.

If we are to judge from the scanty literature of the subject in this country, the amount of interest which has been aroused by the revelation of a new world of micro-organisms, and by the momentous questions which have been raised in connection with them, is far below that awakened in Germany, France, and England. This is not, however, really the case ; for, while we have but few active workers in the difficult fields of inquiry 
which have proved so attractive, especially for the German' and the French savants, there is nevertheless a wide-spread interest in these investigations, and a desire to know their results. But, just here, we are met with a difficulty which has no doubt discouraged many, and perhaps caused some to drop the whole subject in disgust. The results have been so contradictory, and so many would-be savants have uttered opinions entirely opposed the one to the other, that we find it impossible to arrive at any definite opinion, not knowing whom to believe. This being the condition of affairs, it seems to me that it is necessary for us to commence investigating for ourselves, - first making ourselves familiar with what has been done abroad, and then avoiding, if possible, the quicksands into which unfortunate science has too often been dragged by her votaries. One great trouble which we have experienced in this countiy is in judging of the comparative value of the observations of different men who are equally unknown to us. A very plausible article may be written by a very careless observer; or a very cautious observer may fail to give confidence in his results, because of a certain degree of confusion in his language. When experiments are well devised, carefully executed, and described with precision, as is done by such men as Pasteur and Tyndall, we cannot fail to attach great weight to the conclusions reached. And when so accomplished a microscopist as Cohn or Koch asserts that he has seen such and such a thing, or has made such and such measurements, we cannot doubt the reliability of the observation. But sometimes we are deceived by giving credence to a man who has achieved reputation in one line of study, but of 
whose skill and training in the use of the microscope we have no means of judging. Such a man may be a great surgeon, or a great clinician, or a great chemist, and yet be a mere tyro with the microscope. When, then, we see it announced that Dr. So-and-so failed to discover any micrococci in pus, in blood, or what not, taken from a certain source, we are justified in asking, - first, what power did the learned doctor use? second, is he capable of distinguishing micrococci in fluids which contain them beyond question? Or, if he does discover them, we may ask if he is accustomed to making a differential diagnosis between micrococei and inorganic granular material, or unorganized granules of organic origin. This is a decision which the most accomplished microscopist is sometimes unable to make, except by the aid of chemical tests and culture experiments.

To avoid this want of confidence in results, which has naturally grown out of carelessly made observations and contradictory statements, it is desirable that full and minute details should be given of all observations and experiments made, and, whenever possible, that photomicographs should be made of all micro-organisms described, or of a thin stratum of a liquid asserted not to contain any; as, when a sufficiently high power is used, this settles the question of their presence or absence, beyond dispute, and enables other students to make comparisons and measurements which cannot fail to promote the interests of true science.

The National Board of Health of the United States has the credit of first adopting this method of recording the results of scientific investigation, in this direction, as a constant and unimpeachable record of what has 
been seen by the investigator. The commission sent to Havana last summer for the investigation of yellowfever, was instructed to pursue this method, and was accompanied by a photographer and supplied with all the necessary appliances for carrying these instructions into effect.

The superficial reader may find much to criticise in the work of Dr. Magnin, but I am convinced that those who read it carefully cannot fail to be pleased with the truly scientific spirit in which it is written; the fairness with which conflicting opinions are stated; the caution manifested as to the drawing of definite conclusions where questions are still under discussion; and, above all, the extent of his literary researches and the systematic way in which he has arranged the results.

For the naturalist, for the physician, or for the nonprofessional man of general culture, who desires to have accessible in a condensed form the most important results achieved in this line of inquiry up to the present day, this volume cannot fail to be of value; while for the student and the investigator in search of fuller information, the summary given of the labors of numerous individuals, together with the copious bibliog. raphy, which I have brought up to date, will doubtless be of service. Believing this to be true, it has been a pleasure for me to devote a portion of my summer vacation to the translation of this little volume.

G. M. S.

SAlem, Mass., August 1, 1880. 


\section{TABLE OF CONTENTS.}

INTRODUCTION . . . . . . . . . . . . . . . . 11 HISTORICAL . . . . . . . . . . . . . . . 13

\section{PART FIRST.}

MORPHOLOGY OF THE BACTERIA.

CHAPTER I. - ORganization.

§ 1. - Of the Bacteria in General . . . . . . 28

Forms . . . . . . . . . . . . . . . 28

Dimensions . . . . . . . . . . . . 29

Colors . . . . . . . . . . . . . . . 31

Movements . . . . . . . . . . . . . 32

Structure . . . . . . . . . . . . . . 35

Cell-Membrane . . . . . . . . . . . . 35

Protoplasro . . . . . . . . . . . . 36

Cilia . . . . . . . . . . . . . . . 39

§ 2.-Different Modes of Association. . . . . . 43

Form of Little Chain (Torula) . . . . . . . 43

Form of Zooglcea . . . . . . . . . . . 44

Form of Mycoderma, \&c. . . . . . . . . 45

Chapter II. - Classification and Deschiption.

§ 1. - Place of the Bacteria . . . . . . . . . 48

Among Organized Beings . . . . . . . . 53

In the Vegetable Kingdom . . . . . . . . 55

§ 2. - Classification . . . . . . . . . . . . . 59

Characters Generic and Specific . . . . . 60

Classification of Cohn. . . . . . . . . . 65 
§ 3.- Description of Genera and Spectes . . . . 65 Spherobacteria . . . . . . . . . . 71 Micrococcus . . . . . . . . . . . . . 72 Monads . . . . . . . . . . . . . . 78 Microbacteria . . . . . . . . . . . 80 Bacterium. . . . . . . . . . . . . 80 Desmobacteria . . . . . . . . . ' 86 Bacillus . . . . . . . . . . . . . . 87 Leptothrix. . . . . . . . . . . . . . 90 Spirobacteria . . . . . . . . . . . 91 Vibrio . . . . . . . . . . . . . . . 92 Spirillum : . . . . . . . . . . • • . 94

\section{PART SECOND.}

PHYSIOLOGY OF THE BACTERIA.

Chapter I. - Development in General.

\$1. - ORIGIN of BACteria. . . . . . . . . . . 101

Heterogenesis . . . . . . . . . . . . 102

Dissemination . . . . . . . . . . 103

In Air . . . . . . . . . . . . . . . 103

In Water . . . . . . . . . . . . . 106

In the Human Organism . . . . . . . . . 107

§ 2. - Nutrition and Regpiration . . . . . . . . 111

Aliments : Water . . . . . . . . . . . 111

Nitrogen . . . . . . . . . . 112

Carbon . . . . . . . . . 113

Oxygen . . . . . . . . . 115

Temperature . . . . . . . . . . . . 118

Other Agents . . . . . . . . . . . . 121

§3.-REPRODUCTION . . . . . . . . . . . . . 123

Fission . . . . . . . . . . . . 123

Spores . . . . . . . . . . . . . . 126

Sporangia. . . . . . . . . . . . . . 130

Polymorphism . . . . . . . . . . . . 133 
Chapter II. - Development in Different Media.

§ 1. - Rôle of Bacteria in Fermentations . . . . 137 Acetic Fermentation . . . . . . . . . . 139 Ammoniacal Fermentation . . . . . . . 142 Lactic and Butyric Fermentation. . . . . 144

§ 2. - Rôle in Putrefaction and Nitrification • • 148

§ 3. - Rôle in Virulent Affections . . . . . . . 152

Septicemia . . . . . . . . . . . . 152

Charbon . . . . . . . . . . . . 158

Variola . . . . . . . . . . . . 167

Scarlatina . . . . . . . . . . . 169

Measles . . . . . . . . . . . . 169

Diphthèria . . . . . . . . . . 170

Typhoid Fever . . . . . . . . . . . . 171

Glanders, Farcy . . . . . . . . . . 171

Endocarditis . . . . . . . . . . 173

§ 4. - Rôle in Surgical Lesions . . • . . . . 175

Exposed to the Air . . . . . . . . . . 176

Clused . . . . . . . . . . . . 178

Therapeutic Deductions . . . . . . . . 185

Conclusions . . . . . . . . . . . . . 188

Bibliography . . . . . . . . . . . . 191

$\operatorname{Index}$. . . . . . . . . . . . . . 223 


\section{LIST OF PLATES.}

PLATE

OPPOSITE PAGE

I. The Cilia of $B$. termo and $S$. voluntans. (Drysdale and Dallinger) . . . . . . . . . 40

II. Different Modes of Grouping of the Bacteria . . . 47

III. Saccharomycétes and Schizomycétes . . . . . 58

IV. Disease Ferments of Wort and Beer. (Pasteur) . . 84

V. Different Forms of Bacteria. (Cohn) . . . . . 95

VI. Different Forms of Bacteria. (From Photo-micrographs by Dr. Sternberg) . . . . . . . . . 98

VII. Dissemination of the Bacteria. (From Photo-micrographs by Dr. Sternberg) . . . . . . . . 100

VIII. Reproduction of Bacillus Ulna, by Spores. (Photomicrographs by Dr. Sternberg) . . . . . . . 127

IX. Formation of Spores in Bacillus, \&c. (Koch) . . . 153

X. Spirillum Obermineri and Bacillus Anthracis. (Koch). 268 


\section{THE BACTERIA.}

\section{INTRODUCTION.}

"Corruptio unius est generatio alterius."

LucRetios, De Revum Natura.

OF all the studies which have for their object the inferior organisms, those which relate to the bacteria offer, without contradiction, the greatest interest, as they touch the most divers problems, which, it is true, are the most difficult and the least known in biology. The history of these minute organisms is, in truth, related to that of spontaneous generation, to that of the fermentations, to the pathogeny and therapeutics of a great number of virulent and contagious affections, and, in a more general manner, to all the unknown which, notwithstanding the efforts of modern science, still surrounds the origin of life and its preservation.

If the relation of these inferior organisms to the origin of living beings is yet obscure, their rôle in the preservation of life is better known. It is known that organic matter, once produced and become solid, so to speak, cannot again enter into the general current until it has undergone 
new transformations, metamorphoses produced, according to some savaruts, farored, according to others, but, without contradiction, accompanied by the development of bacteria; ${ }^{1}$ and, withont wishing to attribute to these organisms a finality which is repugnant to our monistic conception of the universe, it may be said that it is thanks to them that the continuation of life is possible on the surface of the globe.

But, if these studies are full of interest, their field is so vast that we cannot flatter ourselves that we have passed over the whole of it with equal care. The little time that has been accorded us for the composition of this thesis will be our excuse for the inevitable imperfections which will doubtless be found in our work.

1 The bacteria: such is the subject which has been imposed upon us; but it is certainly useless to give the reasons which have caused us to study not only the bacteria properly so called, taking the word in its most restricted sense, but all the organisms which are comprised under the names of bacteria, vibrios, schizomy cétes, schizophytes, etc. 


\section{H IS T O R I C A L.}

The bacteria are the lowest organisms, situated upon the limit of the two kingdoms, animal and vegetable, and are thus defined by the botanists who have most recently occupied themselves with them:-

"Cells deprived of chlorophyll, of globular, oblong, or cylindrical form, sometimes sinuous and twisted, reproducing themselves exclusively by transverse division,' living isolated or in cellular families, and having affinities which approach them to the algæ and especially to the oscillatoriæ."

But, before arriving at this degree of relative precision, the history of the bacteria has passed through the most diverse vicissitudes. At one time considered as animals, at another taken for vegetables, transported from the algæ to the fungi, one author has even gone so far as to refuse to them the nature of living beings. ${ }^{2}$ This diversity of opinions is due to the minuteness of their dimensions and the difficulties with which their observation is surrounded.

1 Reproduction by spores has been proved to occur in Bacillus subtilis, and it seems altogether probable that other species are reproduced in the same way. - G. M. S.

2 Polotebnow. 
Although an historical statement of the progress of our knowledge of these minute organisms has been given in several publications, we think it best to make here a new historical summary, which will be completed by an indication of the principal papers relating to them which have been published recently.

The first observer who perceived bacteria was Leeuwenhoeck. As early as 1675, while examining by chance with his magnifying glasses a drop of putrid water, the father of microscopy remarked with profound astonishment that it contained a multitude of little globules, which moved with agility. The following year he recognized the presence of bacteria in fæces and in tartar from the teeth; and, if he has not named them, it is easy to assure one's self by the description which he has given of their form and of their movements, and by the figures which accompany these descriptions, ${ }^{1}$ that the organisms observed by him are truly Bacteria, Vibrios, and perhaps even Leptothrix.

In 1773 O. F. Müller endeavored to classify these organisms. He made of them a group of infusoria, under the name of Infusoria crassiuscula, and established two genera, - the g. Monas and Vibrio; the first characterized as follows: "vermis inconspicuus, simplicissimus, pellucidus, punctiformis," comprising the following species: Monas termo, atomus, punctum, ocellus, lens, mica,

1 Leeuwenhoeck. Opera omnia, Lugd. Batav., 1722, 11, p. 40, fig. A to G. 
tranquilla, lamellula, pulvisculus, uva, which it is impossible to identify with the species at present recognized. The genus Vibrio "vermis inconspicuus, simplicissimus, teres, elongatus," enclosing under thirty-five specific names, with the true bacteria, some organisms belonging to other classes of the animal and vegetable kingdoms.

In the classification of the infusoria given byBory de Saint-Vincent in the "Encyclopédie Méthodique" (1824) and afterwards in the "Dictionaire Classique d'Histoire Naturelle" (1830) the bacteria are distributed in two different families of the microscopic gymnodæ, the monadaires and the vibrionides. Besides the monads, properly so called, of which the Monas termo has been preserved by the greater part of the bacterologists, the monadaires include some veritable infusoria, which have no relation with the monads. It was the same with the vibrionides, of which the genera Vibrio and Mellanella included some beings very different in their organization. Indeed; beside some veritable vibrios, bacteria, and spirilla, constituting the genus Mellanella, Bory placed some nematoid worms, such as the Anguillula of vinegar.

With Ehrenberg (1838) and Dujardin (1841) the family of the vibrioniens was established upon characters more homogeneous, and their species upon distinctions truly scientific. But these two observers, followed in this by M. Davaine, deny completely the affinities of the elongated bacteria 
(Bacterium, Vibrio, etc.) with the punctiform bacteria (Monas); and it is necessary to come to the time of MM. Hallier, Hoffmann, Cohn, and the greater number of recent botanists, in order to see these two forms brought together anew: In fact, Ehrenberg defines his vibrioniens, which he arranges between the volvociner and the closteria "animals, filiform, distinctly or apparently polygastric, no mucous membrane, naked, without external organs, with the body (like monads) uniform and united in chains or filiform series, as a result of incomplete division." $\mathrm{He}$ included in this class" all filiform bodies gifted with proper movement and formed of articles, dividing them into four genera:-

1. Bacterium: filaments linear and inflexible; three species.

2. Librio: filaments linear, snakelike, flexible; nine species.

3. Spirillum: filaments spiral, inflexible; three spe cies.

4. Spirochoete: filaments spiral, flexible; one species.

A fifth genus, including but one species, the Spirodiscus fulvus, with filaments in a helix, inflexible, disposed in contiguous layers, has not been seen since Ehrenberg. Let us add that Ehrenberg often attributed to them a complex structure, stomachs more or less numerous, a proboscis, cilia serving as organs of locomotion, all characters that more recent observers have failed to find. Nevertheless, we must make an 
exception in favor of the cilia, of which the existence has been recently verified in the case of several of the bacteria by divers botanists, among others by MM. Cohn and Eug. Warming.

Dujardin (1841), in his " Histoire Naturelle des Zoophytes," preserved the family of the vibrioniens of Ehrenberg among the infusoria, characterizing them as follows: "fiiliform animals, extremely slender, without appreciable organization, without visible locomotive organs." He made but few modifications, of which the principal consisted in uniting Spirochoeta with Spirillum, Dujardin. Rejecting the character that Ehrenberg drew from the rigidity of the spirilla, the Spirochota plicatilis, Ehrb. became the Spirillum plicatile, Duj.; but, as will be seen later, this change has not been maintained. Dujardin, then, classed the baoteria in :

1. Bacterium : filaments rigid, with a vacillating movement.

2. Vibrio: filaments flexible, with an undulatory movement.

3. Spirillum: filaments spiral, movement rotary.

Until this time the bacteria had been considered as animals placed at the foot of the series. Subsequently the tendency to place them in the vegetable kingdom became more and more pronounced.

Already, since 1853, M. Ch. Robin had pointed out the relationship of the bacteria and of the 
vibrios with Leptothrix. This opinion, which was not favorably received by the authors who adopted nearly all of the generic groups of Ehrenberg and Dujardin, is to-day accepted by many botanists, above all since the labors of Cohn. (See below: classification.) At all events, it is to M. Davaine (1859) that we are indebted for clearly pointing out that the vibrioniens are vegetables, nearly allied to the algæ, and especially to the confervæ.

This same author, having observed some motionless bacteria, thought it necessary to give this character great consideration, and to establish a fourth group, the genus Bacteridium, which he added to the three others admitted by Dujardin; but in this creation he was less happy than in his placing the vibrioniens among the vegetables; for we shall see further on that this character of mobility or of immobility is not absolute, and that it depends upon the age of the bacterium or upon certain conditions relating to the medium in which it is placed.

The most recent complete exposition of the classification and of the ideas of $\mathbf{M}$. Davaine is found in the "Dictionnaire Encyclop. des Sciences Médicales," art. Bactéries (1868). It may be summed up as follows:-

Filaments straight Moving sponta-\} Rigid. . BaCteridum.

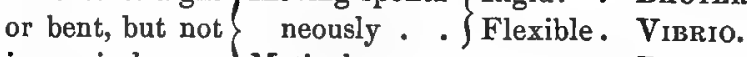
in a spiral . Motionless .... Bacterididu. Filaments spiral ........ SpIRILl du. 
The genus Bacterium comprises six species, B. termo, catenula, punctum, triloculare, or articulatum, already described by Ehrenberg and Dujardin, and B. putredinis and capitatum, new species of M. Davaine, established, the first for a bacterium producing rot in plants, the second for a species, swollen at the extremity, observed in some macerations.

The genus Vibrio includes twelve species, $V$. lineola, tremulans, rugula, prolifer, serpens, bacillus, synxanthus, and syncyanus of previous authors and the $V$. lactic, butyric, and tartaric right, discovered by $\mathbf{M}$. Pasteur in these different fermentations.

In the genus Bacteridium, M. Davaine places five new species, - the "Bactéridies charbonneuse, intestinale, du levain, glaireuse, et des infusions." He includes also the ferment which, according to M. Pasteur, occasions the "sickness of turned wine."

Finally, the genus Spirillum includes the species S. undula, tenue, volutans of Ehrenberg, $S$. rufum and leucomoenum of Perty, and S.plicatile, Duj.

From this moment the history of the bacteria enters upon a new phase. The labors of M. Pasteur upon the inferior organisms and their rôle in fermentation, the researches of MM. Davaine and Hallier upon the bacterium of charbon, and the micrococci of contagious maladies, call the attention of chemists and of pathologists to these or- 
ganisms and especially to the bacteria. Their origin, their evolution, the physiological peculiarities of their nutrition and reproduction, are the object of numerous labors, and give rise to passionate discussions relating to the subject of spontaneous generation, polymorphism of fungi, theories of fermentation, and the pathology of virulent and infectious maladies. For this reason an exposition of these researches, often contradictory, is extremely difficult. We will make it succinctly, insisting especially upon the labors relating to the classification of the bacteria, and reserving to ourselves the privilege of returning to the history of several points, when we approach their study in the special chapters of this thesis.

The first important memoir published after that of M. Davaine upon the bacteria is that of M. Hoffmann, in 1869. He demonstrates: First, that the bacteria are plants, having a very distinct cellular organization; second, that they can only be classified in accordance with their form and size, at first into monads and linear bacteria, and the latter into microbacteria, mesobacteria, and megabacteria; (M. Hoffmann includes with the linear bacteria, Vibrio, Bacterium, and Leptothrix, which are bacteria united in a chaplet;) third, that mobility or immobility is not a specific character, but may present itself in the same species under the influence of changes of temperature, of density of medium, etc. M. Hoffmann studies also the origin of the bacteria, and rejects the hypothesis of a spontaneous generation. As to 
their rôle in the phenomena of the decomposition of organic bodies and in fermentations, M. Hoffmann confesses "that, with the exception of yeast. and of the acetic and butyric ferments, all the rest is still enveloped in obscurity."

M. Cohn is the naturalist who, in our days, has occupied himself the most with the bacteria. In 1853, he published his first researches upon this subject. The genera Zoogloea, which he established at this time for the bacteria arranged in gelatinous masses, diffused or more or less crowded together, was not a happy creation. It was adopted at first by $\mathbf{M}$. Rabenhorst who, in his work on the fresh-water algæ of Europe, places them after the palmellaceæ, while he classes the other bacteria, Vibrio and Spirillum, in the family of the oscillatoriæ. The Zoogloea are later abandoned by their author as a generic group, and are preserved only as the name of one of the diverse transitory stages through which the bacteria pass in the course of their evolution (Zoogloea, Leptothrix, Torula).

Twenty years later the same savant commenced the publication of a series of "Memoirs" upon these organisms (in his "Beiträge zur Biologie der Pflanzen"). In the first paper the author gives an exposition of his researches upon the organization, development, and classification of the bacteria, and upon their action as ferments.

M. Cohn considers them as a well-defined group, - the schizospores, belonging to the algæ, at the commencement of the series of the phycochroma- 
ceæ, with several families with which the different genera of bacteria have many affinities. He recognized, however, that the absence of chlorophyll approaches them, at least from a functional point of view, to the fungi. Upon this point we may say that for other botanists this character is decisive, and the bacteria are classed as fungi.

M. Nägeli, who takes this view, describes them under the name of Schizomycetes. Cohn divides the bacteria into four tribes, comprising six genera :

1. The Sphorobacteria or globular B.

2. The Microbacteria or rod B.

3. The Desmobacteria or filamentous B.

4. The Spirobacteria or Spiral B.

We will return to this classification.

In 1874, M. Th. Billroth, in his researches upon the Coccobacteria septica, expressed opinions entirely different from those of Cohn. According to Billroth, the bacteria differ considerably in form according to the medium in which they are placed and divers circumstances. He claims that they constitute but a single species, the Coccobacteria septica. This vegetable organism can present itself under the form of globular articles (coccos) or under that of rods (bactérie). These two forms may reproduce themselves by becoming elongated and dividing transversely, or may pass the one into the other. Billroth claims to have found both forms united in a single filament, a 
fact which in his opinion demonstrates conclusively their relationship. Each of these two forms can also present variations of size, in accordance with which he establishes the following divisions :

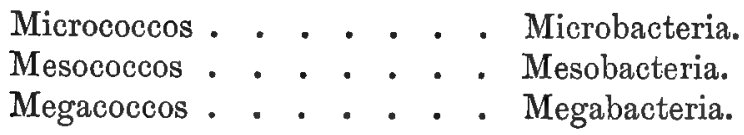

And varieties of association which give rise to the following names :-

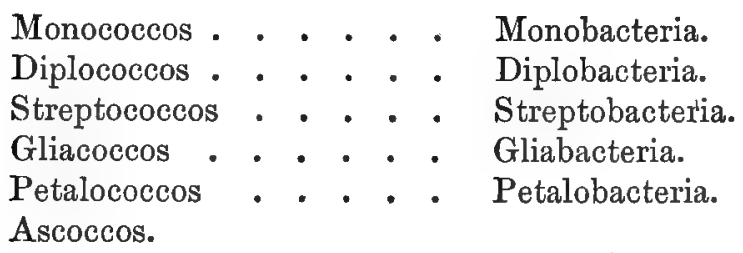

The following year (1875), Cohn, in the second part of his "Researches" upon the bacteria, criticised the opinions expressed by Billroth in the preceding memoir. Cohn believes that we should regard as distinct genera and species all the bacteria having a particular form and acting differently as ferments, so long as the proof of their identity has not been demonstrated in an evident manner. Coming back also to the affinities and classification of these organisms, he insists anew upon their near relationship to the Phycochromacer; and, no longer distinguishing the bacteria as a special family, he distributes his different genera in a group, which he calls Schizophytes, which includes the greater part of the 
Chrococcese and of the Oscillarice. We will return to this subject when we speak of the classification of the bacteria.

In 1876, appeared in the same number of Cohn's "Beiträge" two important papers. The first, by Cohn, treats of the influence of temperature upon the bacteria, of their origin, of the formation of spores in the Bacillus of hay infusion, and of charbon. The second, by Koch, gives the result of his researches upon the bacteria of charbon, the Bacillus anthracis.

Koch has been able by skilful cultivation to follow the complete development of this Bacillus, and to witness the formation of spores, of which the vitality is very great, and which are the principal agents of the transmission of this terrible malady.

I must still indicate, in addition to these special works, a quantity of notes and of memoirs scattered through the reviews and periodical publications.

The list will be found in the bibliography appended to this work. I must also cite the recent work of M. Nägeli upon "The Inferior Fungi and their Rôle in Infectious Maladies." The learned professor of Munich has studied the diverse fungi which produce decompositions. He divides them into three groups, - the Mucorini, the Saccharomycetes, and the Schyzomicetes, which correspond to the bacteria. According to Nägeli, 
the bacteria are fungi which produce putrefaction.

In presence of these opinions, so diverse, as to the nature of the bacteria and their classification, we will finish by saying with Cohn :-

"So long as the makers of microscopes do not place at our disposal much higher powers, and, as far as possible, without immersion, we will find ourselves, in the domain of the bacteria, in the situation of a traveller who wanders in an unknown country at the hour of twilight, at the moment when the light of day no longer suffices to enable him clearly to distinguish objects, and when he is conscious that, notwithstanding all his precautions, he is liable to lose his way." 



\section{PART FIRST.}

\section{MORPHOLOGY OF THE BACTERIA.}

\section{CHAPTER I.}

\section{ORGANIZATION OF THE BACTERIA.}

WHEN bacteria develop in a liquid in a sufficient quantity, they become visible to the naked eye. They appear either as a slight cloud, or gathered in little masses in the liquid, or forming a pellicle upon its surface, or as a deposit upon the walls of the vessel and upon the objects contained in the liquid. However, we must hasten to say with M. Cohn, that the fact of the absence of all turbidity in a liquid does not exclude the possibility of the presence of bacteria. In liquids more dense than water (serum, lymph, etc.), when the refractive power of these corpuscles is the same as that of the liquid, their presence may not be revealed by the naked eye. We will add that sometimes their color serves to indicate their presence in a liquid, although this color is often very feeble, and can only be perceived when a considerable thickness of the liquid is examined. If we examine these clouds, these accumulations, these deposits, with the microscope, we see that 
they are formed of a myriad of little bodies isolated or grouped, globular or linear, gifted or not with motion, sometimes colored. These variations constitute so many characters which require to be studied with some detail.

\section{$\S 1$. Bacteria in General.}

Form. - The bacteria, as understood to-day by most botanists, when considered in their separate state, are of two principal forms, - globular bodies, or monads, and bodies more or less filiform, or bacteria properly so called.

The globular bacteria comprise organisms round$\mathrm{ed}$, ovoid, sometimes elongating themselves into a tube (Warming). The Monas crepusculum of Ehrenberg may be taken as a type. This form includes also the Micrococcus of Hallier, the $\mathrm{Mi}$ crosporon of Klebs, the round forms of the Amylobacter of M. Trécul, and perhaps the Microzyma of M. Béchamp. We will see farther on that these are very probably phases of development of the spores of bacteria, properly so called.

The bacteria, not globular, present a greater diversity of form; they may be straight, undulating, or twisted in a spiral.

The rectilinear bacteria are in some exactly cylindrical throughout their whole extent; and in this case they form very short cylinders, as in the Bacterium, Cohn, or cylinders of which the length is several times as great as the thickness, as in the Bactéridies (Bacillus ulna Cohn); others are 
swollen in the middle, with their extremities rounded, such as certain forms of Vibrio serpens (Warming); others again are fusiform, swollen in the middle and attenuated at the extremities, Bacterium fusiforme (Warming); rectilinear bacteria swollen at the two extremities are met during the life of certain species, $B$. lineola and $B$. termo, for example, above all when they are transported to a more favorable medium: this modification usually precedes segmentation; finally, one meets sometimes bacteria swollen at one extremity only; the swollen part presents often a clear point and sometimes an evident spore: we shall see later the signification of this peculiarity. With these claviform bacteria we may include the Bacterium capitatum Dav., the Helobacteria of Billroth, and certain Amylobacter, with heads of the Ficus carica, etc. (Ch. Robin).

The undulating bacteria constitute the Vibrios properly so called ( $V$. rugula, serpens, etc.).

The spiral bacteria of which the turns are more or less elongated are named Spirillum, Spirochoeta, etc.

Dimensions. - The dimensions of the bacteria oscillate between the most variable limits, but in a general way it may be said that they are the smallest of all microscopic beings. Some of them are situated at the extreme limit of our highest magnifying powers; and their proportions, as to 
length and thickness, are comprised within the limits of errors of observation.

The globular bacteria are the smallest, and the dimensions of some species are so minute that they cannot be measured directly.

The largest are the Spirillum, which attain a length of $\frac{2}{10}$ of a millimetre. Between these two extremes, there are all intermediary sizes possible. The dimensions of some of the bacteria are given below :-

Monas vinosa, 0.5 to $1 \mu$, in diameter; length 3 to $4 \mu$.

Bacterium termo, breadth 0.6 to $0.8 \mu$; length 2 to $3 \mu$.

Vibrio lineola, breadth 0.5 to $1 \mu$; length 3 to $8 \mu$. Bacillus ulna, , 0.7 to $1 \mu$;, 5 to $8 \mu$. B. anthracis, $\quad, 1$ to $2 \mu ; \quad, 10$ to $50 \mu$. Spirillumvolutans, , $\quad 7 \mu ; \quad, 10$ to $40 \mu$.

Several authors, considering exclusively this character of dimensions, have divided the monera and the bacteria according to their size. Thus Hoffmann recognizes in addition to the monera, only the microbacteria, the mesobacteria, and the macrobacteria. In the same way Billroth classifies the monads according to their dimensions into micro, meso, mega coccos, and the bacteria into micro, meso, mega bacteria. Finally, Klebs separates the Micrococcos from the Microsporines, which do not differ from them except by their smaller dimensions, both forms being able to pass to the state of bacteria (rods). 
Color. - The phenomena relating to the color of bacteria have only recently been pointed out. "But little attention has been given to the color of the bacteria, regarded generally as colorless," said M. de Seynes in 1874; and recently M. de Lanessan, "The bacteria are ordinarily quite colorless." However, M. Cohn had already insisted upon the globular bacteria chromogènes, or of pigmentary fermentation, and upon the colors produced by different monads, which have long since been studied by microscopists.

Upon this subject, let us observe that the bacteria which are colored belong to two very different groups. First, colored organisms always known as such, but which were not formerly included with the bacteria, as the different monads, which have become the Micrococcus prodigiosus, cyaneus, aurantiacus, Cohn, etc.; the second group includes the bacteria properly so called, which absorb the coloring matter of vegetables upon which they are fixed as parasites, or of the media in which they live. This is the case with the bacteria observed by M. de Seynes upon the Penicillum glaucum, and perhaps with the Vibrio synxanthus and syncyanus, Ehrenb., which give to milk a yellow or blue color according to the species. We will return to this subject when we speak of the nutrition of the bacteria.

As to the purple-colored monads, they have been especially studied as early as 1838 by Dunal, then by Morren and Ehrenberg, and in our own day by Ray-Lankester, Cohn, Klein, and finally 
by Warming and Giard. They are found in various media - in sea-water, in hot sulphur springs, in fresh water containing animal or vegetable matter in a state of putrefaction. They appear sometimes upon bread, meats, and in general upon cooked food placed in a humid atmosphere. The different colors which they present are red, yellow, orange, and blue. It is probably to analogous organisms that we must attribute the blue color presented by pus under certain circumstances, the green and blue color studied by M. Chalvet, and the orange-yellow, bright red, and blue colors observed by C. Eberth in perspiration.

In Norway, red bacteria appear in summer in such masses that the borders of the sea are sometimes colored of an intense red (Warming).

Movement. - The bacteria are met in two different states. They are active or motionless; but it is now well settled for the greater number that the same species may present itself sometimes in a state of repose, sómetimes in a state of movement.

The movements of the bacteria are of two kinds, - a movement of the corpuscle upon itself and a movement of translation. The first is sometimes nothing more than a molecular or brownien movement, which occurs in the smallest forms. But at other times it is more extended, and consists in a movement of rotation round the axis, or a bending of the body. This flexibility is, above all, 
observed in the long forms, the Bacillus, the Vibrions, etc. As to the movement of translation, it is very variable; at one time slow, at another rapid, it is in relation with the length and form of the bacterium. M. Cohn has well described all the modifications of movement in the following lines :

"Almost all the bacteria possess two different modes of life, characterized by repose and by movement.

"In certain conditions, they are excessively mobile; and when they swarm in a drop of water, they present an attractive spectacle, similar to that of a swarm of gnats, or an ant-hill. The bacteria advance, swimming, then retreat without turning about, or even describe circular lines. At one time they advance with the rapidity of an arrow, at another, they turn upon themselves like a top; sometimes they remain motionless for a long time, and then dart off like a flash. The long rod-bacteria twist their bodies in swimming, sometimes slowly, sometimes with address and agility, as if they tried to force for themselves a passage through obstacles. It is thus that the fish seeks its way through aquatic plants. They remain sometimes quiet, as if to repose an instant: suddenly the little rod commences to oscillate, and then to swim briskly backwards, to again throw itself forward some instants after. All of these movements are accompanied by a second movement analogous to that of a screw which moves in a nut. When the vibrios in the 
shape of a gimlet turn rapidly round their axis, they produce a singular illusion: one would believe that they twisted like an eel, although they are extremely rigid."

The causes of these movements have been sought, at first, in the supposed animal nature of the bacteria, and the movements assimilated, consequently, to voluntary movements; but this opinion can no longer be sustained, as similar movements are to be seen in a great number of vegetable organisms, such as the diatoms, the oscillatoriæ, the spores of algæ and some fungi, etc. They have also been attributed to the existence of locomotor appendices (Ehrenberg); but, although the cilia, denied at first by most microscopists, have been seen since in nearly all the bacteria, the botanists who have best studied them, M. Warming, for example, recognize that it is scarcely probable that these organs are the cause of their movements, for " one meets some examples in which the body remains motionless while the cilia are in violent agitation, and others in which the body moves while the cilia remain inert, or dragging behind."

The movements appear to depend rather upon the nutrition, or respiration, and especially upon the presence of oxygen (Cohn); indeed when this gas is wanting the bacteria become motionless. Immobility may also be produced by want of nutriment, poisoning by different toxic substances, (chloroform, iodine, etc.), dessication, etc.

The attempt has been made to use the characters derived from the existence or absence of 
motion, and the form of the bacteria, in order to classify them; but what has just been said shows clearly that these transitory phenomena cannot be taken for generic or specific characters.

Structure. - It was for a long time believed that the bacteria were constituted of amorphous masses of protoplasm, or of solid rods. The researches of Hoffmann have shown that they have a true cellular structure. We shall describe, then, successively, their membrane, the contents, and the cilia; which may be considered as belonging to the protoplasm.

Cell-membrane. - The extreme minuteness of the bacteria usually prevents a direct demonstration of the cell-membrane, and the existence of this envelope has not, heretofore, been clearly demonstrated except by indirect proofs; chemical reactions, for example.

Thus Hoffmann verifies the existence of a cellular envelope when "the contents, which is a transparent plasma, are partly coagulated, as sometimes happens, or disappear, and are then replaced by air which shows precisely the form of the normal bacterian cell." Warming, also, has not been able to see the membrane, "which only appears distinctly when a vacuole has formed just against the periphery."

On the other hand, the action of chemical agents upon bacteria proves that they have an envelope of cellulose, which is colored by tincture of iodine; 
is not destroyed by caustic potash, ammonia, or even acids; and resists putrefaction for an exceedingly long time. In this respect, it resembles the membrane of cellulose of vegetable cells (Cohn).

We should add that Cohn claims to have succeeded with high powers in seeing directly the cell-membrane. On the other hand, Warming has never succeeded in so doing. The last observer remarks also that the resistence of bacteria to acids, to alkalis, etc., does not seem to prove the existence of a membrane, "inasmuch as this may be the result of a particular condition of the plasma, which in all the bacteria is of a more consistent nature than in other plants."

Finally, the membrane may be, in certain bacteria, tender, flexible and susceptible of movements of torsion. In others, it is rigid and incapable of bending. Cohn thinks also that it may swell and dissolve into mucilage, a fact which would explain the origin of this substance in the Zoogloea.

Protoplasm. - The contents of the cell is a nitrogenous substance, generally colorless, more highly refractive than water.

In the smallest species, this protoplasm appears homogeneous; but in the bacteria of medium size, and above all in the large species, the contents of the cell encloses portions more highly refractive, vacuoles, special granules, and sometimes diverse coloring matters. 
Cohn has first pointed out the movements of the protoplasm, in which currents occur, above all in the central portion, the peripheral portion remaining homogeneous and motionless. The vacuoles are also found in the central portion; Warming, however, who has observed them in Monas Okenii, Vibrio rugula, $V$. serpens and Spirillum undula var. littoreum, has sometimes seen them in the middle of the plasma, at another near the exterior wall.

The granules which are seen in the protoplasm were considered by Ehrenberg as stomachal vesicles or ovules. They are of two sorts; the one, highly refractive and not bordered by a dark circle, are considered by Warming as nothing more than mere compact. masses of protoplasm; the second, also highly refractive, but surrounded by a dark circle, resemble drops of oil, and have been taken for fat granules; but the recent researches of Cramer, Cohn, and Warming have proved that some of them, at least, are formed of crystalline sulphur. They are not soluble either in hydrochloric acid or in water, but they are dissolved in absolute alcohol, in hot caustic potash and sulphite of soda, in nitric acid and chlorate of potash at ordinary temperatures, and in bisulphide of carbon, when the membrane, which is permeable with difficulty, has been previously destroyed by sulphuric acid. Although their small dimensions and great refractive power prevent them from being distinguished with certainty as crystals of sulphur, as they are doubly refractive to polarized light their crystalline nature cannot be doubted. 
'These globules of sulphur have been observed in Monas Okenii, Bacterium sulphuratum, Ophidomonas, and the different species of Beggiatoa, both in fresh water, in putrid sea-water, and in thermal sulphur waters. It will be seen when we speak of the physiology of these organisms what their rôle is in the elimination of sulphur and the formation of sulphuretted hydrogen.

We have said, in speaking of the colored bacteria, that some borrow their color from the surrounding medium, and that others, on the contrary, have a color of their own. The protoplasm of the latter contains a granular coloring matter, which is ordinarily yellow, blue, or red. The red coloring matter is most common, and this has been best studied, and appears to be the best known.

One of these colors which gives a pink tint (peach color) to Bacterium rubescens, Ray-Lank. (Clathrocystis roseopersicina, Cohn); Monas vinosa, Ehrb., M. Okenii, Cohn; M. gracilis, Warming; Rhabdomonas rosea, Cohn; M. Warmingii, Cohn; Ophidomonas sanguinea, Ehrb.; Merismopedia littoralis, Rabenh. ; etc., has been studied by RayLankaster, who has given to it the name of bacterio-purpurine. It is insoluble in water, soluble in alcohol, ether, carbolic acid, glycerine, and fatty oils, - characteristics which make it resemble chlorophyll. It has also a characteristic spectrum.

Other red coloring matters which appear to be different have been found in Monas prodigiosa, Ehrb.; Bacillus ruber, Cohn; and Micrococcus fulvus, Cohn. These should not be confounded with 
the purple coloring matter of other algæ, as that of the Porphyridium cruentum, which comes from a mixture of chlorophyll and of phycoerythrine. The bacteria never contain chlorophyll.

In this connection, it is interesting to recall the protoplasmic constitution of the Amylobacter of Trécul. These organisms are, according to Van Tieghem, bacteria, to which he has given the name of Bacillus Amylobacter, and which does not differ from $B$. subtilis, except by a specific character, extremely transitory, - the presence of amorphous starch, formed and stored in reserve during the period of growth, to be again used later, and consumed during the process of reproduction.

Citia. - These appendages which were described by Ehrenberg in the Bacterium trilocular have not been seen since. To-day, recent researches permit us to say that cilia exist without doubt in all the true bacteria, - Bacillus, Bacterium, Spirillum. They have been perceived in a great number of forms, - Spirillum volutans, Sp. undula, Vibrio rugula, Spiromonas Cohnii, Vibrio serpens, and several species of Bacillus. It is only in the smallest of the bacteria that it has hitherto been impossible to demonstrate their presence. They have, however, been recently seen by Dallinger and Drysdale in Bacterium termo. Warming has perceived as mariy as two or three on one extremity in Ophidomonas sanguinea Spirillum volutans var. robustum, and Vibrio rugula. 


\section{PLATE I.}

Taken from "Monthly Microscopical Journal," of Sept. 1st, 1875.

FIG 1. - a. B. termo magnified with the same power as $b$, which is a specimen of Spirillum volutans, showing flagella at each end.

Fig. 2. - B. termo, as seen with a power of about 600 diameters.

FIG. 3. - The same as seen with $\frac{1}{50}$ and second eye-piece $(3,700$ diameters).

FIG. 4. - B. termo, seen with flagellum at one end, the light coming in the direction of the arrow.

FIG. 5. - The same object when it moved at right angles to its former position, the light coming from the same direction, cansing the sight of the flagellum to be lost.

FIG. 6 represents one $B$. termo which was in a still condition, but one flagellum moving. The light came in the direction of the arrow. When the end marked $2 b$ was in focus, a flagellum was seen, but none at the end $c$. When the end marked $1 a$ was focused carefully, the flagellum at that end was seen, and lost at the end $d$.

FIG. 7. - The true form of $B$. termo.

FIG. 8. - The form as shown by the "supplementary stage" illumination before flagella were found, showing the pointed termination of the body at $a, b$. 


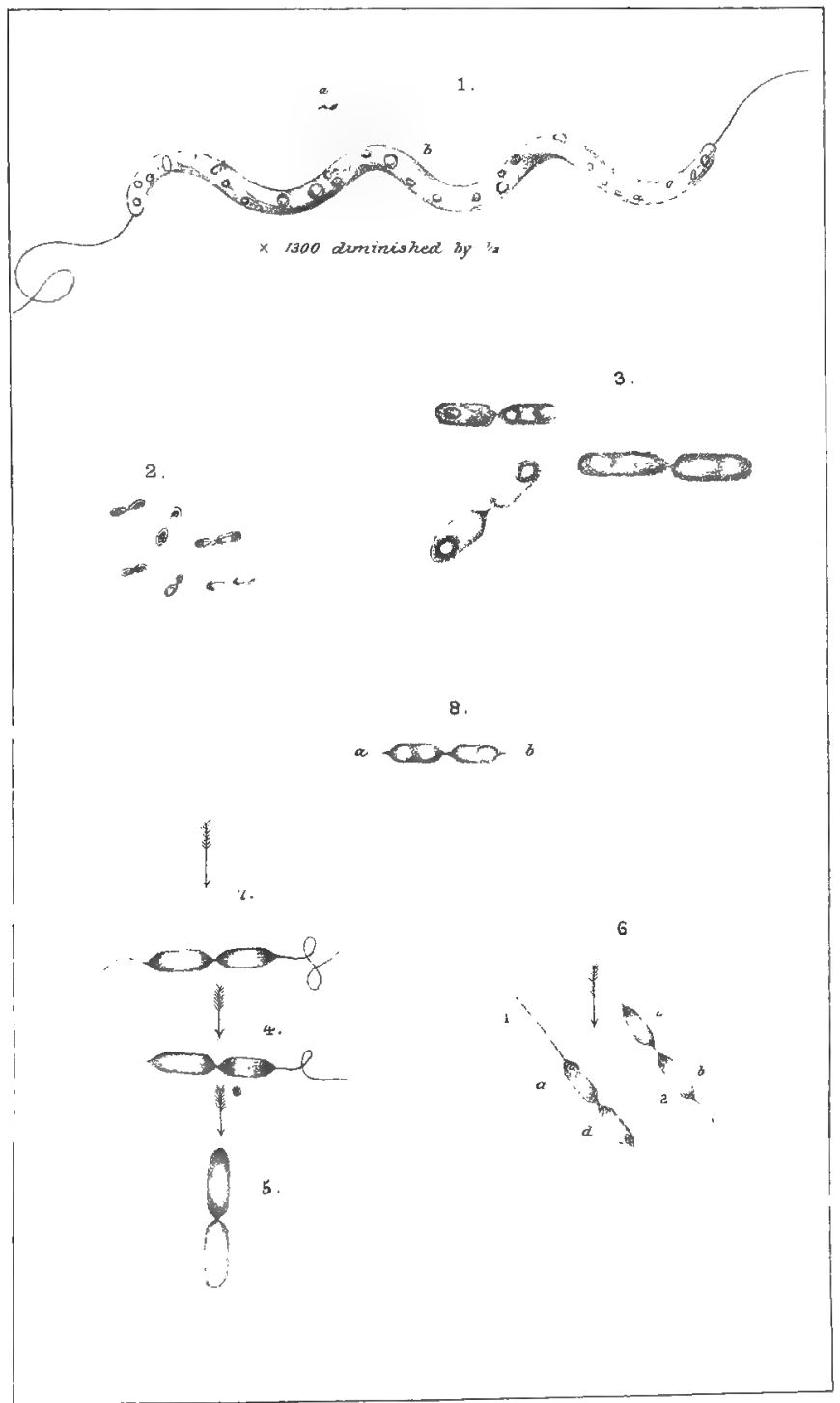

A Merselitith 



\section{EXTRACT FROM PAPER "ON THE EXISTENCE OF FLAGELLA IN BACTERIUM TERMO," BY W. $H$. DALLINGER, F.R.M.S., AND J. J. DRYSDALE, M.D., F.R.M.S.}

"In the summer of 1872 , some very fine specimens of $S$. volutans came under our notice, and were carefully examined. We were enabled fully to confirm Cohn's discovery, and demonstrated repeatedly the presence of a pair of swiftly lashing flagella. The drawing at $b, F i g .1$, was made from a specimen magnified 1,300 diameters (diminished by $\frac{1}{2}$ ).

"Having closed for the present our Monad researches, we have been stimulated by the hope that the experience gained by these might enable us to prosecute similar investigations into the true life history of bacteria. We have commenced the work this summer, and, guided by the analogy of $S$. volutans, we have been led to make several continuous efforts to find whether or not there existed a flagellum or flagella in B. termo. The task, of course, under the best circumstances, must be a a difficult one, from the extreme minuteness of the object. We tried each of Powell and Lealand's powers successively, from the $\frac{1}{12}$ to the $\frac{1}{50}$, but with no definite result. Repeatedly we both saw vortical action at both the distal and proximal end of the termo, but could not absolutely see the organ causing it. But in the process of our investigations we made very close and careful observations on the fission of this form: we do not purpose now to describe the process, but merely to point out a phenomenon that further confirmed our suspicion of the presence of an invisible filament. In separating into two, the jointed rod of sarcode which is in process of division shakes to and fro at the constriction, as if the constricted part were a hinge; and at length a clear separation takes place to quite the length of the original termo (sometimes longer), and there is no visible connection between them; nevertheless they act as one creature, so that if one moves in any direction, the other goes with it, just as the two parts did before separation; showing that, although we cannot see the connection, there must be one; and the presumption was that it was a fine filament, such as we detected in the fission of some monads. ${ }^{1}$ We could make no further progress in the question apparently; but our attention was called to the new th objective prepared by Messrs. Powell and Lealand, with which we were soon supplied. We used it at first with the 'supplementary stage' for very oblique illumination, supplied by the same makers, and this has the advantage of throwing the light in only from one direction. We were soon convinced of the exquisite performance of the glass when used as an immersion. Amphipleura pellucida was not merely seen to be striated clearly and sharply, but the stria

“M. M. J., vol. s., p. 55; and vol, xl., p. 8." 
were resolved into beads with the third and fourth eye-pieces. In like manner the fine strix in Surirella gemma were instantly shown to be beaded, with perfect and brilliant definition, with the second eye-piece. Navicula rhomboides and an extremely delicate specimen of Pleurosigma attenuatum which had resisted every thing below a $I_{16}^{1}$ th immersion, showed beaded striæ perfectly. We were therefore encouraged to try again to discover flagella in the termo. Some of our specimens, nourished in Cohn's nutritive fluid, were placed in a drop of distilled water, and put upon the supplementary stage on an ordinary slide covered with the thinnest cover. The utmost delicacy and tact in manipulation of the light is the great desideratum; but, with this, enough may be secured to work with the fourth eye-piece. The light may be made to enter the objective at almost every angle, but it is always projected in a direction at right angles to the stage; and the first thing we observed when the objects were sufficiently slow in their movements, and at right angles to the light, was that the ends of the termo, which we (and all other observers, as far as we know) had taken for round, proved themselves to be conical, terminating in a sharp point. The usual appearance of $B$. termo, as seen with a magnification of about 600 diameters, is seen in Fig. 2 ; whilst the same seen with a magnifying power of 3,700 diameters ( $\frac{1}{3}$ th and second eye-piece) is seen in Fig. 3, where a globular granule is seen in the end of each half. But with the method above referred to, the best conditions being secured, the two ends of the bacterium were distinctly pointed, as seen at $a b, F i g .8$, and after nearly five hours of incessant endeavor a flagellum was distinctly seen at one end of each of two termos which were moving slowly across the field. The discovery was not sudden and transient, but lasted for at least twenty minutes. The exquisitely delicate flagellum was lasling rapidly the whole time; and one of its frequent conditions is shown in Fig. 4, the arrow indicating the direction of the light: but if the termo turned round at right angles, as in Fig. 5, all trace of the flagellum was gone, showing that its discovery depended entirely, all things being equal, upon its position in regard to the light.

"But this observation was made only by one of us, the other not being present; and in pursuance of our plan we determined to see it again, convincing ourselves separately, and then together. After many hours of labor, this was accomplished; and Fig. 6 shows one of two instances which we both saw together at the same time and in the same instrument. It was lying still, obliquely across the field, the light coming in the direction of the arrow. Both ends were not perfectly in focus at the same time, but in focusing the end marked $2 b$ (Fig. 6) the flagellum was distinctly seen, and was seen also to coil and lash; but no flagellum was then seen at the end $c$ of the same object; but by bringing it into delicate focus it presented the aspect seen at $1 a$ (Fig. 6), which really represents the same object at the same time, only with the other end in the focus, while the end marked $d$ corresponding to $2 b$ of $F i g .6$ was in its turn slightly out of focus, and the flagellum lost to view. This observation, made together, was as satisfactory as could be desired; and it 
was thus demonstrated that there was a flagellum at both ends of the ordinary B. termo.

"It will of course be understood that it is by no means an easy matter to secure the demonstration; and whenever we repeat it, it must always be with nearly the same amount of trouble and patience, although we can now with the ordinary condenser detect the vortical action, both in front and (occasionally) behind the termo, as we never did before. But the demonstration of the ultimate structure of a fixed object - as for instance Amplipleura pellucida - must be looked upon as a matter of great ease in comparison; and that for many reasons, the foremost being the motion and the minuteness of the object, the swift play of the flagella, their similarity in optical properties to the fluid in which bacteria live, the difficulty of retaining them in focus, and of getting them in such a position in relation to the light as to make demonstration possible. Of course, all this would be removed if dead bacteria would answer, but they very rarely (indeed only once) have done so with us. The flagellum needs to be in slow motion to properly show itself; for even with the more delicate and minute monads it is a difficult thing to show the flagella in dead forms, since in the majority of cases they appear to be attracted round the body of the creature."

\section{§ 2. - Of the Different Modes of Grouping of the Bacterta.}

The bacteria are found in different media in two states, - free, isolated (unicellular bacteria), or united several together, either in chains, in filaments, or in masses of greater or less extent, and sometimes by the aid of a mucous substance in which they are imbedded.

The free unicellular bacteria are found in the Spirillum, Bacillus, Monas, etc. When they are united, they are grouped in the following modes :-

1. Form of a little chain: Torula, Leptothrix. - The usual method of multiplication among the bacteria is by fission ("scissiparité"); each corpuscle divides transversely, and gives birth to two 
new individuals, which sometimes become separated completely the one from the other, to form unicellular bacteria, sometimes remain united; and segmentation again occurring in each portion, a chain is formed of articles more or less numerous.

When these chains are formed of spherical bacteria, they have been called torulos; if they are formed of filiform bacteria, they correspond to leptothrix (Robin). The morphological difference between the torula and the leptothrix consists in the fact that in the first the articles are separated by constrictions, while this is not the case in the second. It is also to be remarked, according to Cohn, that the microbacteria never take either of these forms. Warming states, however, that he has met the torula form in Bacterium lineola, $B$. catenula, and $B$. termo (?).

Billroth has called these two forms of bacteria streptococcos and streptobacteria. He has even considered it necessary to create the words diplococcos and diplobacteria for organisms constituted only of two articles.

2. Form of Zoogloea. - Generally, when bacteria are rapidly multiplying, they remain grouped in masses, swarms, or Zoogloea. In the latter condition, they are closely pressed against each other in the midst of a viscous substance, hyaline, homogeneous, colorless, and constituting masses more or less diffused or definite, in irregular globes, bunches, or tubes, swimming in the water or near its surface. When the bacteria multiply abundantly, the cells become removed from each 
other, so as to leave between them greater intervals. The masses sometimes attain a diameter of several centimetres.

The gelatinous substance in which the bacteria are included seems to be produced by a thickening and jellification of this cell-membrane, or by a secretion from their protoplasm, but the latter view seems more plausible than the former ( $\mathrm{De}$ Lanessan).

It is cornmonly the spherical bacteria (Micrococcus) and the microbacteria (Bacterium) which are found in this state.

The filiform bacteria and the spirilla are never found in gelatinous masses (Cohn). Ray-Lankester, however, claims to have met the Spirillum tenue, in the form of zoogloea, and Klein the Spirillum undula and rosaceum (Warming).

The form of Zoogloea, properly so called, gelatinous and thick, has never been found by Warming in infusions of sea-water.

According to the terminology of Billroth the zoogloea are called gliacoccos and gliabacteria (from $\gamma \lambda i$, mucus substance).

3. Form of Mycoderma. - In certain cases, the bacteria unite on the surface of the water, or of the liquid in which they are developed, to form a thick layer, a sort of membrane. This production called mycoderma by Pasteur is a sort of zoogloea, but differs from it by the absence of the intermediary mucus substance. The bacteria are, however, motionless, although living, since they come to the surface to be in contact with oxygen, which is necessary to them. 
The petalococcos and petalobacteria of Billroth correspond with the mycoderma of Pasteur.

4. Swarms. - We have seen that the filiform and spiral bacteria do not, usually, form zoogloea. These microphytes are either disseminated and free, or united in swarms. This formation may be seen, for that matter, in all the bacteria, when, thanks to abundant nourishment, they multiply rapidly and gather together in considerable masses. They are very active in these swarms, whilst in the zoogloed the corpuscles are motionless, because of the intermediary glairy substance.

Pulverulent precipitate. - When the nutritive elements are exhausted in a liquid, the bacteria. cease to multiply, fall to the bottom of the receptacle, and the liquid gradually becomes clear. The deposit formed in this manner may acquire a thickness very appreciable to the naked eye. The bacteria which form this precipitate are not dead, but in a state of temporary repose; and if a new supply of nutritive material is added to the liquid, they are seen to multiply anew, until this has been exhausted (Cohn). 



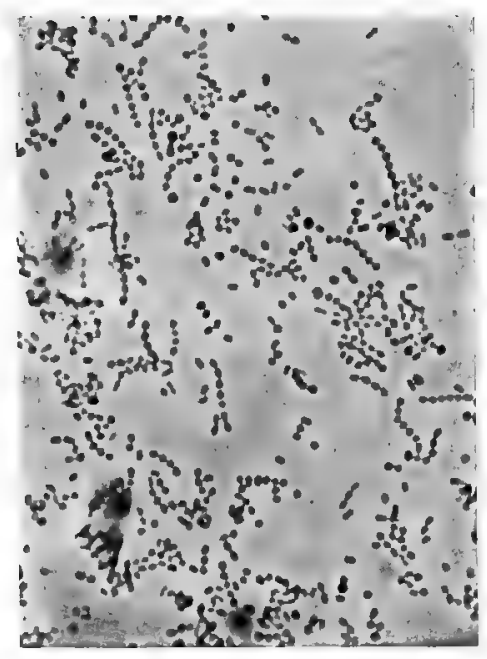

Fic. I.

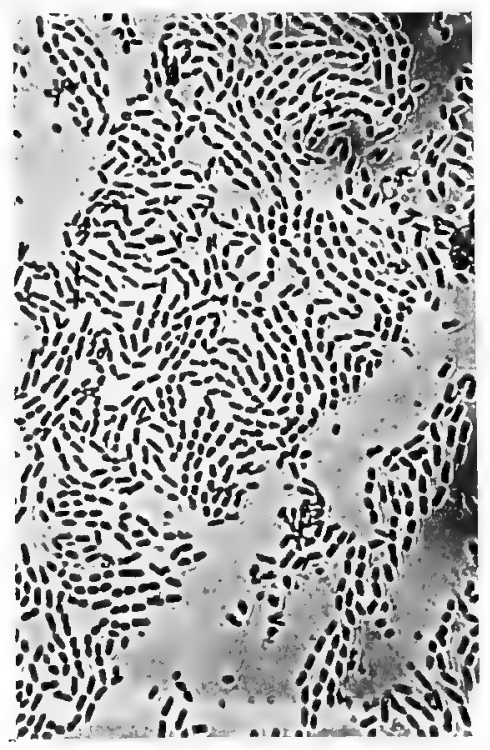

FIG. 3 .

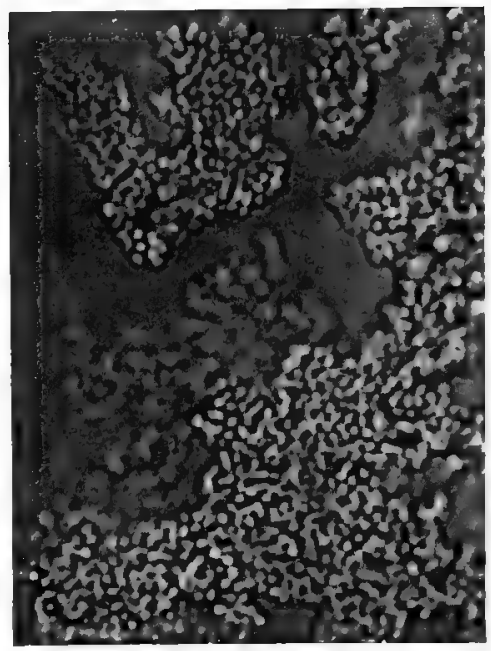

Fig. 2.

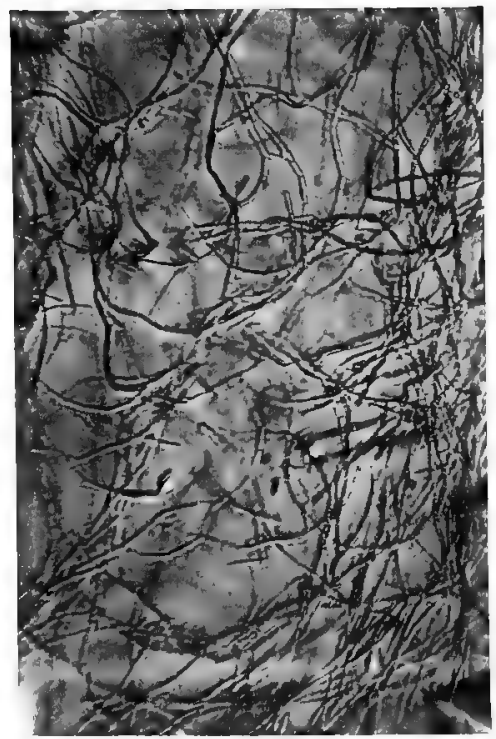

FIG. 4 . 


\section{PLATE II.}

DIFFERENT MODES OF GROUPING.

From photo-micographs made in Havana and New Orleans; copied by permission of the National Board of Health.

Frg. 1. - Torula form of spherical bacteria (Micoderma aceti Pasteur) from rotten banana, New Orleans, April, 1880. $\times 1500$ diameters by Zeiss's $\frac{1}{18}$ in. objective.

FIG. 2. - Zooglcea form of spherical bacteria developed in culturecell containing blood of leper. $\times 600$ diameters.

Fig. 3. - Mycoderma, from surface of foul gutter-water. New Orleans, April, 1880. $\times 400$ diameters by Becks, $\frac{1}{6}$ in. objective.

Fig. 4. - Leptothrix form of desmobacteria developed in yellowfever urine, exposed in laboratory, Havana, July, 1879. $\times 400$ diameters by Becks, $\frac{1}{5}$ in. objective. 


\section{CHAPTER II.}

CLASSIFICATION OF THE BACTERIA.

\section{§ 1. - Position of the Bacteria.}

THE place of the bacteria in the scale of beings, for a long time undetermined, demands to be established with precision; not only for the naturalists, who only view the question from a systematic point of view, but above all for the biologists who study the rôle of these organisms in the chemical or pathological phenomena with which they are associated. According to $\mathrm{Ch}$. Robin, not to define the animal or vegetable nature of these organisms, " is for them as grave as it would be for a chemist to leave undecided the question as to whether it was nitrogen or hydrogen, urea or stearine, which he had obtained from a tissue, or of which he is following the combinations in certain operations."

This determination is, to-day, possible; and, if there are still some differences of opinion among naturalists as to the place of the bacteria among the cryptogams, there is but one opinion as to their vegetable nature.

It is surprising to see a savant like M. Pasteur " not to pronounce positively upon the vegetable 
or animal nature of several of the ferments which he has studied," and of which some belong to the bacteria.

We shall first indicate rapidly the characters which permit us, at first, to recognize certain species of bacteria as organized beings, to determine if they are animal or vegetable, and finally to classify them either among the algæ or among the fungi.

Distinction of Bacteria from Inorganic Substances. - The question as to whether bacteria are organized beings can only be raised in relation to the smallest species, those Micrococci which are scarcely perceptible with the highest powers; the organized nature of the other organisms of the same group has never been questioned, even by the earliest observers, who all, since Leeunhoeck, have, without exception, taken them for animals or vegetables. But the smallest forms of bacteria may be confounded with various matters, with organic particles, molecular granules, fat globules, etc. "These productions, which are found in considerable quantity in the liquids or in the tissues of animal or vegetable origin, often resemble so closely, in form, size, and grouping, the spherical bacteria, that it is absolutely impossible to guard one's self against confusion, unless the most minute precautions are taken in making the observations" (Cohn).

The detritus, the amorphous powder of precipitated molecules of inorganic substances, even when 
they exhibit the brownien movement, are easily enough distinguished from Micrococci by optical signs, their angular form, their less refractive power, and finally by their reaction with certain chemical agents; above all if they are mineral substances, crystalline bodies, etc.

It will not be the same with molecular granules of organic nature. They have as common characters, their rounded form, their notable refractive power, movements. Nevertheless, their form is less regular, more angular, their color variable, their refractive power always less. In doubtful cases, Tiegel has given a method which enables us to distinguish them from Micrococci. It consists in warming the glass slide which supports the corpuscles under examination, if they are "Coccos," they are seen to move in a manifest manner. This does not occur in the case of molecular granules.

It is these productions which render it very difficult to observe the phenomena which occur during the coagulation of milk. The caseine separates in the form of extremely minute globules having a very rapid molecular movement. But we may distinguish these from bacteria by the use of liquor potassæ, which dissolves the former without attacking the latter.

As another example of pseudobacteria, I will mention, after Cohn, the form which fibrine assumes when it separates from the plasma of the blood. It disposes itself in very slender filaments, closely resembling filamentous bacteria. 
Fat globules, which are found of all sizes, are often of the same dimensions as Micrococcus, and are very difficult to distinguish from the latter. The difference in refractive power is slight, and the action of re-agents, such as ether, is not certain in mucilaginous solutions. Hiller, who has paid especial attention to the means of recognizing bacteria, divides them into two groups:-

A. The optical signs: comprising 1. The characteristic vegetable form, rods, leptothrix, this he recognizes as of little use, as in this case there is no doubt; 2 . The characteristic movements of the monads; 3 . The mode of growth and of multiplication; 4 . The mode of junction of the granules.

B. The chemical signs: 1. False zooglcea become softened and diffuent under the action of liq. potasse, and are coagulated by the direct application of alcohol; 2. In sections of tissues, after an hour of maceration in liq. potassa, diluted ${ }_{1}^{\frac{1}{0}}$ th, the monads are colored brown by iodine, while fat granules are not.

But, in truth, the method of cultivation, extolled by Cohn and Wollf, is the best means of distinguishing the bacteria. "The distinction of pseudobacteria," says the first of these authors, "from veritable globular bacteria is a problem which our microscopists cannot resolve, in every case, with the desirable certainty. It is only by a study of their mode of development that this distinction can be made. The globules which divide and develop in form of chains are organized beings; when this does not occur, we are dealing with pseudobacteria." 
This is not, however, exactly the opinion of Nägeli, who seems to consider movement as the surest distinctive characteristic.

"There are," he says, "but three distinctive signs which enable us to recognize with some certainty that granules under observation are organisms, - spontaneous movement, multiplication, and equality of dimensions, united with regularity of form.

"The most certain character is movement in a straight or curved line, - a movement which inorganic granules never present. One should take care not to be deceived by movements which are caused by currents in the liquid under observation. Nor should one allow himself to be deceived by the tremulous motion, called molecular movement, in which the granules do not really change their position. These movements are seen in most cells, and even in those of the Schizomycetes, and inorganic bodies themselves present it.

"Multiplication is a character less important than movement. When among granules some are found united in pairs, it may be supposed with probability that division and multiplication are taking place. When rods are bent at an angle, one may predict their division in two parts.

"Finally, as to size and form. Granules of different size and of a more or less irregular form ought not to be considered as belonging to the group of segmented fungi; if, on the contrary, the granules offer dimensions perfectly equal, and a spherical or oval form, the distinction is more 
uncertain: they may belong to the schizomycetes or be of inorganic nature."

Place of the bacteria among organized beings. Distinction between animals and vegetables. - The characters which serve to distinguish the inferior animal organisms from the inferior vegetable organisms are of two orders, optical and chemical.

A. The optical characters are drawn from the general form, the movements, and the mode of reproduction.

The morphological characters have no value except among the larger species of bacteria. If we bring together a Spirillum and a Spirulina, Kuitz., their affinities will be apparent to every one. It is not the same for the large species of Bacillus, of which the relations with the Oscilla toria are evident. The rod form seems very special, but it does not necessarily imply the vegetable nature of the organisms which possess it. Finally, the spherical bacteria, - Monas and $M i$ crococcus, - resemble entirely by their form some infusorial animals.

Movement is not a more special character. It is now well proved that it does not belong exclusively to animals, and that it is met with in a certain number of the inferior vegetables.

In fact, the anatomical characters are not always absolutely reliable; but it is from these alone that Cohn first, then Davaine, have recognized the bacteria as vegetables.

B. Chemical characters. Robin depends upon 
these characters to demonstrate the vegetable nature of the bacteria. He takes for point of departure the notions of general physiology as given by De Blainville in the following points:-

1. We find in animals various elementary substances of the same kind as in plants, and reciprocally.

2. The ternary compounds predominate, however, in plants ; and the quarternary, nitrogenized, are more abundant, on the contrary, in animals.

3. In both, the fundamental cellular structure is the same; at least originally for the greater number, and always in the most simple of organized beings, etc. . . .

"It results from this, then," continues M. Robin, "that so long as there is no digestive tube one can only distinguish plants from animals by the study of their elementary principles, and of the chemical reactions which these exhibit in general; by the study, in particular, of the reactions which the predominance of ternary cellulose principles over all others gives to plants, and that of nitrogenized principles in animals, at all periods of their existence."

Starting from this basis, Robin made numerous attempts to find in liquor ammonia, concentrated, as prepared for use in laboratories, a reagent for corpuscles of a vegetable nature. In effect, ammonia dissolves the eggs, the embryos, of all animals, the bodies of all the inferior infusoria, attacks the spermatozoa, etc., whilst it leaves absolutely intact all the varieties of cellulose and 
the anatomical reproductive elements of plants, whether it is used cold or boiling.

As to the other chemical characters praised during recent years, we will content ourselves with mentioning, concentrated acetic acid, which causes all animal tissues to become pale, whilst it is without action on bacteria (Luckonvsky); iodine, and sulphuric acid (Letzerich), etc.

Hematoxyline (Luckonvsky) and fuschine (Hoffmann) color the bacteria deeply. One ought, then, no longer to give to the bacteria, as do some recent authors, the names of microscopic animalcules, - infusoria, microzoa, etc., and other expressions without precision, or consecrating an error.

Let us add that some naturalists of high repute, Häckel for example, have created for these minute beings, monera, protoplasts, flagellata, diatoms, etc., an intermediary kingdom between the animal and vegetable, - the Protista.

Place of the Bacteria in the Vegetable Series. The vegetable nature of the bacteria once established, it remains now to determine to what class of vegretables they belong.

Are they, algæ or are they fungi? This is the question which divides the naturalists.

It is true that it is to-day very difficult to find a characteristic of these two classes of vegetables, both having, in a general manner, identical forms, similar reproductive apparatus, etc.; and, if it is impossible to confound a Basidiomycete with a Florideæ, for example, it is not the same when 
one studies the inferior species. The only character which appears general is the presence of chlorophyll in the algæ and its absence in the fungi. But, if we adopt this distinctive character, and apply it in all its rigor, we are obliged to separate in the inferior algæe some forms very nearly related, and which do not differ from their relations except in this particular. And this is exactly what happens in the case of the bacteria.

In truth, the bacteria, although entirely without chlorophyll, have numerous affinities as to form, movement, etc., with the oscillatoriaceo, and, according as one or the other of these characters have appeared to predominate, the bacteria have been classed as algæ or as fungi.

It is thus that Davaine, Rabenhorst, then Cohn, struck above all by the resemblance of form, mode of grouping, and of multiplication, have placed the bacteria among the algæe. Cohn insists, above all, upon the affinities of the filiform bacteria with the beggiatoa and the leptothrix; of the micrococcus, and of the bacterium, with the chroococcaceoe. $\mathrm{He}$ at first placed them at the commencement of this last series; but we shall see further on that in his last publications he has disseminated them among the oscillatoriaceæ and the chroococcaceæ.

Robin and Nägeli, on the other hand, insist rather upon the affinities of the bacteria with the yeast plants, which are incontestably fungi, and they include them in this class.

Robin says expressly: "All the corpuscles described under the name of Bacterium termo, $B$. 
punctum, etc., Zoogloea, Micrococcus, and many others, are vegetable cells, spores of fungi, of several distinct species certainly; spores, or reproductive bodies of the first order, derived one from another, either by germination, fission, or from a mycelium; reproductive bodies, in a word, of the order of those which Tulasne has arranged under the name of conidia, etc."

Nägeli establishes in the inferior fungi which produce decompositions three very natural groups.

1. The Mucorini, or mould fungi;

2. The Saccharomycetes, or budding fungi, which produce the fermentation of wine, beer, etc.;

3. The Schizomycetes, or fission fungi, which produce putrefactive processes. This last group is formed of our bacteria (Micrococcus, Bacterium), etc.

Sachs solves the question by uniting the algæ and fungi in a single group, the thallophytes, in which he establishes two series exactly parallel, one comprising the forms with chlorophyll; the other, the forms which are deprived of it, and preserving in a transverse direction the morphological affinities of these organisms.

As this classification is yet but little known, we think it best to give it in the following table :-

\section{THALLOPHYTES.}

Forms with chlorophyll.

Forms without chlorophyll.

Cl. 1. Protophytes.
A. Cyanophyceæ (Oscil- A'. Schizomycetes (Bac- latoriaceæ, etc.).
B. Palmellaceæ. teria). B'. Saccharomycetes (Ferments). 


\section{PLATE III.}

Saccharomycetes and Schizomycetes (Nägeli), developed in urine (of yellow-fever patient) exposed in laboratory of the Yellow-fever Commission, Havana, July, 1879. Reproduced by permission of the National Board of Health.

Fig. 1. - Photo-micrograph made with Beck's $\frac{1}{6}$-in. objective and Tolles's amplifier. 400 diameters.

Fig. 2. - Photo-micrograph made with Zeiss's $\frac{1}{18}$-in. hom. im. objective. 1,450 diameters. 


\section{Plate III.}
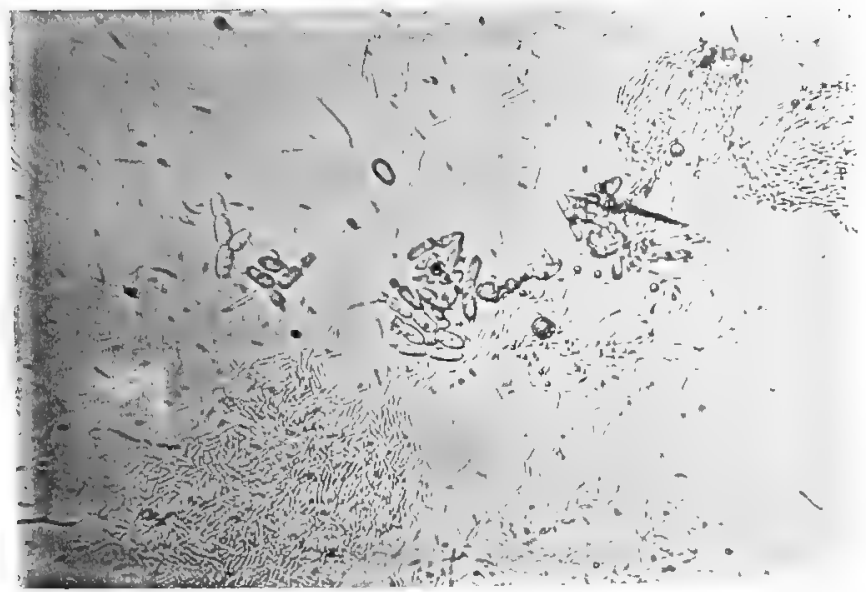

Fili. I.

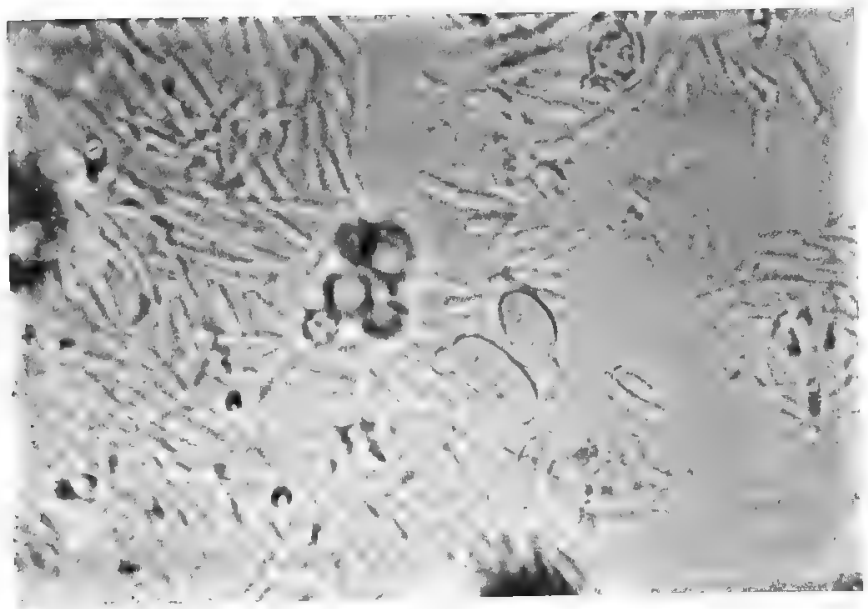

Fin. 2 . 



\section{2. Zygosporez.}
A. Volvocineæ.
A'. Myzomycetes.
B. Conjugueæ and Dia- B'. Zygomycetes. toms.

CL. 3. OOSPOREA.
A. Sphæropleæ.
B. Cœloplasteæ.
C. EEdogoniæ.
Saprolegniæ.
Peronosporeæ.

Cl. 4. Carposporeze.
A. Coleochæteæ.
A'. Ascomycetes.
B. Florideæ.
B'. Ecidiomycetes.
C. Characeæ.
C'. Basidiomycetes.

Our preferences are for this last mode of classification, but obliged, in the description of species, to follow the classification of Cohn, the most complete which has been given hitherto, we must abandon it for the present.

\section{§ 2. - Classification; Generic and Specific Characters.}

The numerous classifications of the bacteria of which we have given an abstract in the historical part of this work, show how variable have been the ideas of the microscopists as to the nature of these organisms.

Before giving the most recent, those among which we will have to choose, it is best to study the characters upon which authors have depended for grouping the bacteria in genera and species, and to estimate the value of these characters. 
1. Generic and specific characters. - These have been drawn from the dimensions, form, movement and evolution of the bacteria.

The size, which, according to Cohn, is the dominating distinctive character, is often indeterminable, even in employing the highest powers. Besides, for a great number of neighboring forms, the differences of measurement given as distinctive are so slight that they cannot serve in practice. Thus, according to Dujardin, the Bacterium termo has a length of $1,7 \mu$, and the $B$.punctum of 1,7 to $0.6 \mu$. Another difficulty presents itself when we examine bacteria formed of several articles. Shall we consider the length of a single article or of the chain, which consists of a number of articles, a number ordinarily variable?

The form of the bacteria and their union in colonies, also offer differences, which have been utilized; but do they depend upon differences truly specific, or do they come from foreign influences, from phases of development of the same organism? Even when one uses these as distinctive specific characters, the form is sometimes of little assistance; since if one refers to the descriptions of Dujardin, the Bacterium termo will be found to have a cylindrical body swollen in the middle, and the $B$. punctum an elongated ovoid body.

As to movement, we have seen that the phenomena of mobility or of immobility sometimes present themselves in the same species, according to age or changes in the medium.

We have left, the mode of development, the 
phenomena of reproduction by fission or by spores, as the only character which can serve to establish our natural genera; but, unfortunately, this has only been ascertained for a small number of bacteria, the Bacillus anthracis, for example.

The genera of bacteria cannot have the same significance as among animals and superior vegetables; they can only be established in accordance with the most prominent characters, reserving the feeble modifications of these generic forms as specific characters.

Are there distinct, well-defined, species among the Bacteria?

The microscopists have given the most diverse opinions upon this subject. Müller, Ehrenberg, Dujardin, Davaine, have admitted the specific distinction of the numerous vibrioniens which they have described. Davaine, however, raises some doubts as to the absolute value of the species established in his time. "Those which are described to-day by the classifiers," he says, "ought to be considered as the expression of types under which are hidden a certain number of distinct species."

Cohn dwells still more upon the impossibility, in which we are to-day, of distinguishing with certainty genera and species among the bacteria. However, he is convinced that the bacteria are divided into species as distinctly as the other plants and inferior organisms. It is only the imperfection of our means of observation which makes it impossible to recognize these differences. This is above 
all true, he says, of the spirilla, which are not only distinguished from the rod bacteria, properly so called; but which present in their species some differences as constant as any well-defined species of alga or of infusoria.

Hallier, Hoffmann, Billroth, Robin, Nägeli, etc., consider the different forms of bacteria in a very different fashion. According to them they are not autonomous species, but phases of development of one or of several species.

According to Hallier, we may see, à propos of the polymorphism of the bacteria, the singular transformations which he has obtained by their cultivation.

According to Billroth, the bacteria belong to a single species of plants, the Coccobacteria septica, with the exception of the Spirillum and Spirochoeta, in regard to which Billroth is not willing to give an opinion. This view has been adopted by a certain number of microscopists, and above all by the pathologists, such as Frisch, Tiegel, etc.

Robin also admits the genetic relation of Micrococcus, Vibrio, Bacterium and Leptothrix, but considers them the distinct and successive phases in the evolution of several species: 1st. Corpuscles described under the name of Bacterium termo, punctum, etc., Micrococcus ; 2d. Mycelial filaments, Vibrio, etc. ; 3. Bacteria, Bacteridies, Microbacteria, etc.; 4th. Leptothrix and forms more advanced.

The opinion of Nägeli corresponds very nearly with the preceding. "As much as I am con- 
vinced," he says, "that the schizomycetes cannot be grouped in accordance with their action as ferments and their exterior forms, and that altogether too many species have been distinguished; so, on the other hand, it seems to me very improbable that all the schizomycetes constitute a single natural species.

"I am rather inclined to suppose that there exists among them a small number of species, which have little in common with the genera and species admitted to-day, and of which each runs through a cycle of determined forms sufficiently numerous. Each of the veritable species of schizomycetes is not limited to presenting itself under the different forms of Micrococcus, Bacterium, Vibrio, and Spirillum, but can also show itself as the agent of acidification of milk, of putrefaction, and as the agent producing several maladies."' However, Nägeli recognizes that it is necessary to distinguish these forms, notably those of Micrococcus, Vibrio, Bacterium, and Spirillum, without, however, losing from view the fact that the organisms thus classified have a very inconstant constitution, and pass continually from one form to another.

Finally, other savants such as M. Pasteur, take less account of the structural characters than of the physiological functions, regarding as a particular species every form of bacterium which is born constantly in a determined medium, or which causes a special kind of fermentation.

Nägeli opposes to this view the following objections. First, he has verified the presence, in 
the same decomposition, of several different forms of schizomycetes. On the other hand, in decompositions quite different, we may observe schizomycetes entirely similar as to their exterior form. Finally, we may change the mode of action of a schizomycete in subjecting it to a certain treatment. One sees that it is truly difficult to form an opinion as to the value of these species purely physiological.

To sum up, the characters which may be used in order to establish genera and speeies in the group of the bacteria are of small number and of very unequal value. Some, characters of form, of dimension, of movement, etc., are often difficult to determine, or have only a relative value; others, characters drawn from development and reproduction, are only known in so few species that they cannot be made to serve as a basis of classification.

One will not be surprised, then, to find that there is no natural classification of the bacteria, and that it is impossible for the naturalists to give one. All those that can be established are provisory, being only based upon the morphology of these organisms. Following the example of all the botanists, we will use an analogous classification, but without wishing to prejudge in any particular the genealogical relationship of the different organisms, which we shall consider as distinct genera and species. 


\section{§ 3. - Classification and Description of the Genera and Species of the Bacteria.}

We have seen in the historical portion of this work, à propos of the classifications which have been given of the bacteria, that, in 1872, M. Cohn, recognizing the numerous relations, absence of chlorophyll, mode of nutrition, etc., which make these organisms a natural family, divided them into four tribes:-

1. The Spherobacteria, or spherical bacteria.

2. The Microbacteria, or B. in short rods.

3. The Desmobacteria, or B. in straight filaments.

4. The Spirobacteria, or B. in spiral filaments.

In the spherobacteria, Cohn has only adopted one genus, the g. Micrococcus, of which the species are divided into three series, - the pigmentary M., or chromogenes, the M. of fermentations, or zymogenes, and the M. of contagious affections, or pathogenes.

The microbacteria include only the genus $\mathrm{Bac}$ terium, with two species, B. termo, Dujardin, and B. lineola, Cohn.

The desmobacteria comprehend the g. Bacillus and Vibrio; the first established by Cohn for the rectilinear filaments is composed of the $B$. subtilis, Cohn (with $B$. anthracis as a variety) and the $B$. ulna, Cohn; the second, characterized by undulating filaments, is reduced to $V$. rugula and serpens, Auct. 
Finally, the spiral filaments of the spirobacteria characterize the gr. Spirillum and Spirochata, which might be united in a single genus comprising Sp. plicatile, tenue, undula, and volutans.

Since then, Cohn, struck with the affinities which each of the preceding genera presents with several genera of oscillatoriaceæ and of chroococceæ, from which the bacteria only differ by the absence of chlorophyll, has established a class of Schizophytes, which includes all the inferior vegetable organisms, provided or not with chlorophyll, multiplying by fission.

We give below the complete table :-

2. Classification of the Schizophytes, Cohn.

\section{TRIBE 1. - GLAEOGENES.}

Cells free or united in glairy families by an intercellular substance.

A. Cells free or united by 2 or by 4 :

Cells spherical . . Chroococcus, Näg.

Cells cylindrieal . SrNeCHOCOCCUs, Näg.

B. Cells united in glairy families, amorphous in state of repose :

a. Cellular membrane, confounded with the intercelIular substance :

1. Cells without phycochrome, very small :

Cells spherical . . Mrcrococcus, Hallier. 
Cells cylindrical . BACteridm, Duj.

2. Cells with phycochrome, larger :

Cells spherical - . Aphanocapsa, Näg.

Cells cylindrical . Aphanothece, Näg.

b. Intercellular substance formed of several menbranes enclosed one within the other:

Cells spherical . . Gldocapsa, Kg. Cells cylindrical . GløotheCe, Näg.

C. Cells united in glairy families of definite form:

a. Families of a single layer of cells disposed in plates :

1. Cells in fours forming a plane surface . Merismopedia, Meyen.

2. Cells without regular arrangement, forming a curved surface:

Cells spherical, families with reticulated rupture . . Clathrocrstis, Henfr.

Cells cylindrical, cuneiform, families divided by constriction . . . CelosPh AsRiUM, Näg.

b. Families with several layers of cells, united in spherical corpuscles :

1. Number of cells determined :

Cells spherical, colorless, arranged in fours . . SARCINA, Goods. 
Cells cylindrical, cuneiform, with phycochrome, without regular arrangement - . GoMPHOSPHARIA, Kg.

2. Number of cells very great and indeterminate:

Cells colorless, very small . . . Ascococcus, Billr.

Cells colored by Polycxstis, Kg. phycochrome Coccochloris, Spr. and larger. . Polycoccus, Kg.

\section{TRIBE 2.- NEMATOGENES.}

Cells disposed in filaments.

A. Filaments not branched :

a. Filaments free or interlaced.

1. Filaments cylindrical, colorless, articulations not very distinet:

Filaments very slender, short . . Bacillus, Cohn.

Filaments very fine,

long. . . . . Leptothrix, Kg.

Filaments larger,

long . . . Begglatoa, Trev.

2. Filaments cylindrical, with phycochrome, articles well defined, НүрнеотнRIX, Kg. $\left.\begin{array}{l}\text { without cellular re- } \\ \text { production . . . }\end{array}\right\}$ 
3. Filaments cylindrical, articulated, with conidia:

Filaments colorless Crenothrix, Cohn. Filaments with phycochrome . . Cham ensiphon.

4. Filaments spiral

without phycochrome:

Filaments, short, light, sinuous . VIBRIo, Ehr.

Filaments, short, spiral, rigid . . . SpIRIllum, Ehr. Filaments, long, spiral, flexible . . SpIrochente, Ehr. with phycochrome:

Filaments long, spiral, flexible . . Sprrulina, Link.

5. Filaments in chaplet: Filaments, without phycochrome . . Streptococcus, Billr. Filaments with phy- $\}$ ANABana, Bory. cochrome . . Y Spermosira, Kg.

6. Filament flagelliform, slender . . . MAStigothrix, etc.

b. Filaments united into glairy families by an intercellular substance:

1. Filaments cylindrical, colorless . . . . Mrconostoc, Cohn.

2. Filaments cylindri- ( СнтноNoblastus. $\left.\begin{array}{l}\text { cal, with phyco- } \\ \text { chrome . . . }\end{array}\right\}$ Limnoclide, Kg.

3. Filaments in chaplet. Nostoc, etc.

4. Filaments flagelliform, slender . . . Rrvularia, etc. 
B. Filaments with false ramification :

1. Filaments cylindri- Cladothrix, Cohn. cal, colorless . . S Streptothrix, Cohn.

2. Filaments cylindrical, with phycochrome

Calothrix, Ag. SCYTONEMA, Ag.

3. Filament in chaplets. Merizomyria, Kg.

4. Filaments flagelliform, slender towards the extremity . .

Schizosiphon, Kg.

Geocychus, Kg.

An inspection of this table shows that each of the genera of the ancient group of the bacteria has been placed beside some genus of oscillatoriaceæ, which it resembles by its organization, Micrococcus and Bacterium, beside Aphanothece and Aphanocapsa; Bacillus, beside Leptothrix and Beggiatoa; Vibrio and Spirillum, beside Spirulina.

These affinities are undeniable, and the advantages of such a classification are manifest; but, in a work like this, we cannot think of employing it. We preserve, then, in a distinct group the schizophytes deprived of chlorophyll, which may be arranged in the four primary divisions of Cohn with the exception of Sarcina, Ascococcus, Crenothrix, etc., and the other genera created recently by this botanist.

Thus we will describe successively :-

1. The Spherabacteria of Cohn; and beside them the different Monas recently studied, - the Micrococ- 
cus described by Hallier in several infectious maladies.

2. The Microbacteria.

3. The Desmobacteria, including Bacillus, Leptothrix, Beggiatoa, and Crenothrix.

4. The Spirobacteria, including the three genera, Vibrio, Spirillum, and Spirochota.

5. Finally, we will give some account of the Merismopedia, Sarcina, Ascococcus, Streptococcus, Myconostoc, Cladothrix, and Streptothrix.

\section{Spherobacteria, Cohn.}

The spherical bacteria are characterized by their rounded or oval form, their small size, often less than $1 \mu$. They are ordinarily isolated, often in pairs (diplococcus), sometimes in a chain of several articles (streptococcus = torula of Cohn), the mycothrix of Hallier and Itzigsohn, or in the form of zoogloea when they are young and actively multiplying, and that of mycoderma, when they are gathered upon the surface of liquids. They have no spontaneous movement, but a simple molecular trepidation.

Functions: "The spherical bacteria are ferments, not producing putrefaction, but substitutions of another kind" (Cohn).

Obs. According to the facts observed by Koch, Cohn, Pasteur, Toussaint, upon the development of certain bacteria, it is very probable that some at least of the spherobacteria are spores of Bacillus or of other bacteria; at least, the micrococci and these spores are identical in form and aspect. 
The spherobacteria include only the genus $M i$ crococcus.

g. Micrococcus, Cohn (Hallier emend. - Microsphoria, Cohn, ante).

Cells colorless, or scarcely colored, very small, globular or oval, forming by transverse division filaments of two or several articles, in form of chaplet, or united in numerous cellular families, or in gelatinous masses, all deprived of movement.

The species are divided into three physiological groups:-
a. M. Chromogenes.
b. M. Zymogenes.
c. M. Pathogenes.

Section (a): Micrococcus Chromogenes.

The pigmentary bacteria grow in the state of Zoogloea upon the surface of the substances which furnish them with nutriment. They are always alkaline; all are avid of oxygen; their morphological characters are identical, and one can only distinguish them by their different coloring properties.

According to Cohn, they are veritable species; for 1 . Their pigments offer the greatest diversity as to chemical action and by spectroscopic analysis, etc.; 2. Each species cultivated in the most diverse media produces always the same coloring matter. 
They are divided into two categories, according as the pigment is soluble or not in water.

\section{Coloring matter insoluble.}

M. Prodigiosus, Cohn (Monas prodigiosa, Ehrb.; - Palmella prodigiosa, Mont.;-Bacteridium prodigiosum, Schroeter).

A red gelatinous mass, pink carmine, developing upon cooked alimentary substances placed in damp air, never before cooking.

It has also been observed in red milk, attributed incorrectly to lesions of the teats, etc. (Cohn).

M. luteus, Cohn (Bacteridium luteum, Schroeter).

A yellow gelatinous mass studied by Schroeter and Cohn upon potatoes.

\section{Coloring matter, soluble.}

M. aurantiacus, Cohn (Bacteridium auriantiacum, Schroeter).

Little drops, or stains, more or less extended, golden yellow, cultivated by Schroeter, upon slices of cooked potato; by Cohn, upon hard white of egg.

M. chlorinus, Cohn.

A glairy yellowish-green pigment found upon hard white of egg, not reddened by acids, but loses its color.

M. cyaneus, Cohn (Bacteridium cyaneum, Schroeter).

Pigment deep blue, observed by Schroeter 
upon cooked potato, and cultivated by Cohn in nutritious solutions. This coloring matter is reddened by acids, and restored to blue by alkalies, just as that which forms when lichens are macerated in presence of ammonia.

M. violaceus, Cohn (Bacteridium violaceum, Schroter).

Violet-blue masses or glairy stains formed of elliptical corpuscles larger than those of $\boldsymbol{M}$. prodigiosus, observed first by Dr. Schneider, then by Schroeter on cooked potato.

Later, Cohn has described the two following new species (1876), which should be included in this group :

M. Candidus, Cohn.

Stains and points white as snow, observed upon slices of cooked potato.

M. fulvus, Cohn.

Little rust-colored drops, consisting of cells, globular or united in pairs, in a tenacious intercellular substance, diameter $1.5 \mu$, observed by Eidam, then by Kirchner, upon horse dung.

It is also to the genus Micrococcus that we must refer the little globular bacteria, gifted with movement, found by Eberth in white, yellow, and red perspiration, and by Chalvet in the pus on the edges of certain wounds, but which should not be confounded with the blue color produced by a Bacterium. 
Section (B): Micrococcus Zymogenes.

Globular bacteria producing fermentations of diverse nature.

M. crepusculum, Cohn (Monas crepusculum, Ehrb.).

Globular cells, colorless, developing in all infusions of animal and vegetable matter undergoing decomposition.

M. ureæ, Cohn.

Oval cells, isolated, diameter $1.5 \mu$ (Pasteur), 1.2 to $2 \mu$ (Cohn) or united by 2,4 , to 8 (torula), in a line, straight, curved, zigzag, or even in cross form. In urine of which it transforms the urea into carbonate of ammonia (Pasteur).

A Torula which appears identical with the preceding Micrococcus, produces the decomposition of hippuric acid into benzoic acid and glycollamine (Van Tieghem).

M. of stringy wine, etc.

Globular cells of $2 \mu$ diameter, in chaplets, found in stringy wine, perhaps identical with the preceding (Pasteur).

A Torulaceæ quite similar is found in certain fermentations of tartrate of ammonia and of beer yeast, with or without the addition of carbonate of potash (Pasteur).

Section (c): Micrococcts Pathogenes.

Spherical bacteria found in affections of a contagious nature. 
M. vaccinæ, Cohn (Microsphoera Vaccinœ, Cohn).

Very small micrococci, $=0.5 \mu$ scarcely, isolated or united in pairs in recent vaccine virus and in the pus of variola pustules. By cultivation, chaplets of from two to eight cells may be obtained, then masses containing sixteen to thirty-two cells of $10 \mu$ and more diameter.

The M. of vaccine virus and of variola are identical, and Cohn regards them as different races of the same species.

M. diphtheriticus, Cohn.

Granular cells, ovoid, measuring from 0.35 to to $1.1 \mu$, isolated or more often united in twos or in a chaplet of four to six cells; sometimes multiplying in colonies and extending themselves in all the diseased tissues, decomposing and destroying them (Ertel).

M. septicus, Cohn (Microsporon septicus, Klebs).

Little rounded cells, of $0.5 \mu$, motionless and crowded in masses or united in chaplets, in the secretion of wounds in cases of septicemia (Klebs), in zoogloea in callous ulcers, in isolated cells, united in pairs, or in chaplets in the serum of epidemic puerperal fever (Waldyer), in all the tissues, vessels, etc., in cases of pyemia and septicemia.

M. bombycis, Cohn (Mycrozyma bombycis, Béchamp).

Cells with a diameter of $1 \mu$, ordinarily united in chaplets of two, three, four, five, or more, in 
the intestine of silkworms sick with "la flacherie" (Pébrine).

In a more recent work, Cohn (Beiträge, 1875, p. 201) gives them an oval form and a diameter of $0.5 \mu$ at the outside.

Hallier has described many other Micrococci in diverse contagious or virulent affections. We will only refer to them in a summary manner: '

M. of the variola of animals, Hallier.

Small M. endowed with active movement, furnished with a very delicate caudal appendage, sometimes united in the form of little elongated rods, found in pustules, spontaneous or inoculated, in the lymphatic canals and the ganglia of animals attacked with variola.

\section{$M$. of rugeola, Hallier.}

Very small colorless M., having often a caudal prolongation, in the sputa and blood of the sick.

M. of scarlatina, Hallier.

M., free or in colonies, on the surface or in the interior of the blood corpuscles, or in chains.

M. of epidemic diarrhoe, Hallier.

M. in intestinal matters with vibrios, cells, and monads. (?)

1 "It is quite probable that Hallier comprises, in part, under the name of Micrococcus the same organisms that I call spherical bacteria : but the doctrine of Hallier concerning Micrococcus, as has already been pointed out by Hoffmann and de Barry, is so covered by inexact assertions and improbable hypotheses, that it is impossible to draw any conclusions from the facts he has observed." - Cous, Beit. II, p. 148. 


\section{$M$. of exanthematous typhus, Hallier.}

M. relatively large, brown, having a rapid movement, sometimes in chains (Mycothrix), in the blood.

M. of intestinal typhus, Hallier.

M. very small, in repose in the blood; larger, endowed with active motions, and furnished with contractile appendices in the dejections.

M. of glanders, Zürn.

Cells free or attached to the blood globules, or even penetrating into their interior, sometimes in chains (Mycothrix) in the blood. M. in chains, very numerous, and endowed with rapid movements, in the lymphatic ganglia, the mucus of the frontal sinuses, and in the chancroid ulcers.

\section{M. of syphilis, Hallier.}

M. numerous, colorless, free or in globules, in gonorrhoea, the primitive ulcer, and the blood of persons suffering from constitutional syphilis.

\section{Monads.}

Beside the Spherobacteria are placed the Monads, not the organisms described under this name by the older microscopists, comprising microphytes, spores, and infusorial animals, but the Monas as understood by botanists of the present day. Thus limited, the Monads include also, besides some microphytes related to the Spherobacteria, and differing from them by their greater dimensions, some organisms of doubtful affinities. 
As in the case of the Micrococci it is very probable that the Monads are only the spores, or lower forms of bacteria higher in the scale. Cohn places the Monas vinosa of Ehrenberg with the Clathrocystis roseopersicina, Cohn (Bacterium rubescens, Ray-Lank.), considering it a spore of the latter.

Monas vinosa, Ehrb.

Cells spherical, oval, regular, of $2.5 \mu$, often united in pairs, formed of a pink substance with granules of a deeper color, having spontaneous movements. Hab., waters containing decomposing vegetable matters (Ehrb. 1838, Ch. Morren 1841, Perty 1852, Cohn 1875).

M. Okenii, Ehrb.

Cells cylindrical; average length 7 to $15 \mu$ (Cohn), $10 \mu$ (Ehrb.), sometimes from 60 to $80 \mu$ (Warming), diameter $5 \mu$; of a beautiful red color, having a rapid gyratory movement, with a cilium at the posterior extremity or two cilia at the two extremities. Hab., stagnant water (Ehrb. 1836, Eichwald, Weiss, Cohn, etc.).

M. Warmingii, Cohn.

Cell cylindrical, pink, containing at its two rounded extremities some deep-red granules; length 15 to $20 \mu$, width $8 \mu$; movement uncertain, having a vibratile cilium. Hab., brackish water on the coast of Norway (Warming).

\section{M. gracilis, Warming.}

Cells straight, cylindrical, pink, rounded at the two extremities; length $60 \mu$, thickness $2 \mu$; movement slow. Hab., fresh water. 


\section{Rhabdomonas rosea, Cohn.}

Cells pale pink, isolated, fusiform ; eight times as long as broad, having a length of 20 to $30 \mu$, and a width of 3.8 to $5 \mu$; having a slow oscillatory movement, the pink substance containing numerous granules of darker color and vacuoles. Hab., stagnant water.

Ophidomonas sanguinea, Ehrb.

Cells pale pink, spiral, rigid, movement active; thickness $3 \mu$, length of one turn of the spiral, 9 to $12 \mu$. Hab., brackenish waters of Denmark (Warming).

Spiromonas Cohnii, Warming.

Cells spiral, flattened; $1 \frac{1}{2}$ turn of spiral, diam. 1.2 to $3.5 \mu$, width 1.2 to $4 \mu$. Hab., coast of Denmark.

\section{Microbacteria, Cohn.}

Rod-bacteria, cells cylindrical, short, having spontaneous movement.

A single genus, - Bacterium.

g. Bacterium, Duj. emend.

Cells cylindrical or elliptical, free or united in pairs during their division, rarely in fours, never in chains (leptothrix or torula), sometimes in zoogloea (differing from the $\mathrm{Z}$. of spherical $\mathrm{B}$. by a more abundant and firmer intercellular substance), having spontaneous movements, oscillatory and very active, especially in media rich in alimentary material and in presence of oxygen. 
We might, as in the Spherobacteria, divide the rod-bacteria into three groups: 1 . the bacteria of putrefaction, $B$. termo, $B$. lineola, and their varieties; 2 . the Bacteria of the lactic and acetic fermentations, etc.; 3. Chromogenes, B. of colored milk and pus.

B. termo, Ehrb. 1830, Duj. (Vibrio lineola, Ehrb. ex. p. 1838 ; Monas termo, Müller).

Cells cylindrical, slightly swollen in the middle, isolated, sometimes united in pairs, two to five times as long as wide; length 2 to $3 \mu$, thickness 0.6 to $1.8 \mu$; movements oscillatory.

Appears at the end of a very short time in all infusions of animal and vegetable substances; multiplies with rapidity in numerous zoogloea; then disappears as other species, to which it serves as nutriment, are developed. According to recent observations, this bacterium has cilia (Dallinger, Drysdale, Warming). Warming has also found it in the state of torula.

$B$. termo is the veritable agent, the first cause, of putrefaction, it is the true ferment saprogène (Cohn).

M. Warming has recently described two allied forms:-

$B$. griseum, cells larger, more rounded; length 2.5 to $4 \mu$, thickness 1.8 to $2.5 \mu$. In infusions of fresh and salt water.

$B$. littoreum, cells elliptical or elongated, slightly rounded; length 2 to $6 \mu$, thickness 1.2 to $2.4 \mu$. Coasts of Denmark.

B. lineola, Cohn (Vibrio lineola, Ehrb. ex p., Duj., Müller, $\boldsymbol{V}$. tremulans, Ehrb., Bacterium triloculare, Ehrb). 
Cells cylindrical, straight, rarely a little twisted, larger than the cells of $B$. termo, isolated or united in pairs, sometimes in fours, never more; length 3.8 to $5.25 \mu$, thickness attains $1.25 \mu$; movements like those of $B$. termo, but a little more active.

Is found in various vegetable and animal infusions of fresh or salt water, often takes the form of zoogloea containing motionless rods in their mucus substance. Warming has met it in the form of chains composed of eight to ten cells (torula). Its protoplasm is dotted with refractive granules.

It is not known whether $B$. lineola constitutes a specific ferment (Cohn).

The B. fusiform, Warming, differs from the preceding by the form of its body, which is attenuated at the two extremities; length 2 to $5 \mu$, width 0.5 to $0.8 \mu$; plasma not punctated.

Beside these species, which have been well studied, may be placed the following, which demand new investigations:-

B. punctum, Ehrb.

Elongated rods, oval, colorless, having slow movements, oscillating, often united in pairs; length $5.2 \mu$, thickness $1.7 \mu$. Diverse infusions of animal substances.

$B$. catenula, Duj.

Body filiform, cylindrical, often united in three, four, or five; length 3 to $4 \mu$, thickness 0.4 to $0.5 \mu$. In fetid infusions, in typhoid fever (Coze and Feltz). 
Vibrio lactic, Pasteur.

"Articles almost globular, very short, a little swollen at the extremities; length of an article, $1.6 \mu$, of a series, $50 \mu . "$

This vibrio seems to resemble $B$. catenula or $B$. termo. It is developed, according to Pasteur, in sweetened liquids, where it causes the formation of lactic acid and the coagulation of the casein of milk. According to other researches, coagulation of casein results from the influence of a soluble ferment (zymase), and not from an organized ferment.

Acetic ferment (Mycoderma aceti, Pasteur, Ulvina aceti, $\mathrm{K}$ tg.).

"Articles short, constricted, two to three times as long as broad; length $1.5 \mu$, often united in long chains, forming pellicles on the surface of a liquid."

This species is also very similar to the preceding. It must not be confounded with the Mycoderma vini, which may develop in the same media, but which is a fungus of the group of Saccharomycetes.

The acid fermentation of beer seems to bo due to a form of Bacterium resembling B.termo (Cohn), but a little larger than the type. Cohn has found it in beer undergoing acid fermentation, beside oval saccharomyces, elliptical bacteria, having movement, often united in pairs, rarely in fours, etc.

Vibrio tartaric right (Pasteur).

Bacteria similar to those of the lactic fermentation, 


\section{PLATE IV.}

\section{From "Pasteur's Studies on Fermentation." Macmillan \& Co., London, 1879.}

"The engraving represents the different diseased ferments, together with some cells of alcoholic yeast, to show the relative size of these organisms."

Fig. 1 represents the ferments of turned beer, as it is called. These are filaments, simple or articulated into chains of different size, and having a diameter of about the thousandth part of a millimetre (about $\frac{1}{25000}$ inch). Under a very high power they are seen to be composed of many series of shorter filaments, immovable in their articulations, which are scarcely visible.

In No. 2 are given the lactic ferments of wort and beer. These are small, fine, and contracted in their middle. They are generally detached, but sometimes occur in chains of two or three. Their diameter is a little greater than that of No. 1.

In No. 3 are given the ferments of putrid wort or beer. These are mobile filaments, whose movements are more or less rapid, according to the temperature. Their diameter varies, but is for the most part greater than that of the filaments of Nos. 1 and 2. They generally appear at the commencement of fermentation, when it is slow, and are almost invariably the results of very defective working.

In No. 4 are given the ferments of viscous wort, and those of ropy beer, which the French call filante. They form chaplets of nearly spherical grains. These ferments rarely occur in wort, still less frequently in beer.

No. 5 represents the ferments of pungent, sour beer, which possesses an acetic odor. These ferments occur in the shape of chaplets, and consist of the mycoderma aceti, which bears a close resemblance to lactic ferments (No. 2), especially in the early stages of development. Their physiological functions are widely different, in spite of this similarity.

The ferments given in No. 7 characterize beer of a peculiar acidity, which reminds one more or less of unripe, acid fruit, with an odor sui generis. These ferments occur in the form of grains which resemble little spherical points, placed two together or forming squares. They are generally found with the filaments of No. 1, and are more to be feared than the latter, which cause no very great deterioration in the quality of beer, when alone. When No. 7 is present, by itself or with No. 1 , the beer acquires a sour taste and smell that render it detestable. We have met with this ferment existing in beer unaccompanied by other ferments, and have been convinced of its fatal effects.

No. 6 represents one of the deposits belonging to wort. This must not be confounded with the deposits of diseased ferments. The latter are always visibly organized, whilst the former is shapeless, although it would not always be easy to decide between the two characters, if several samples of both descriptions were not present. This shapeless deposit interferes with wort during its cooling. It is generally absent from beer, because it remains in the backs or on the coolers, or it may get entangled in the yeast during fermentation, and disappear with it. Among the shapeless granules of No. 6 may be discerned little spheres of different sizes and perfect regularity. These are balls of resinous and coloring matter that are frequently found in old beer at the bottom of bottles and casks. They resemble organized products, but are nothing of the kind. 


\section{Plate IV.}

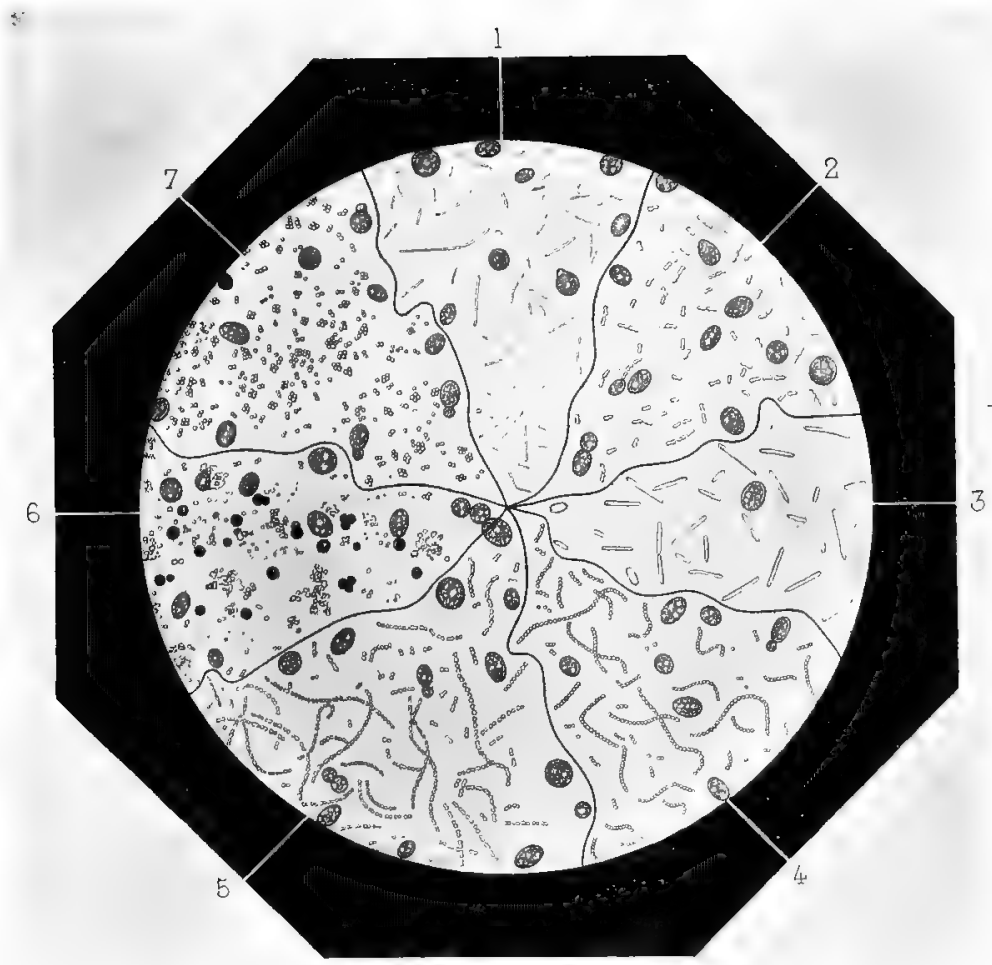



with globular articles, short; diameter $1 \mu$, united in chains of $50 \mu$.

Decomposes racemic acid, causing the right tartaric acid to disappear, and setting free left tartaric acid.

\section{Microbacteria Chromogenes.}

B. xanthinum, Schrœeter (Vibrio synxanthus, Ehrb.).

"Bodies cylindrical, slightly flexible, formed of corpuscles rarely exceeding five in number; length of an article, 0.7 to $1 \mu$. In tainted cow's milk, to which it gives a yellow color."

B. syncyanum, Schroeter ( Fibrio syncyanus, Ehrb.).

This Bacterium, which has the same characters as the preceding, has been observed in sour milk, to which it gives a blue color.

B. cerıginosum, Schroter.

In greenish blue pus.

These B. chromogenes resemble entirely the lactic vibrios, $B$. termo or catenula. According to Robin, colored milk contains colorless vibrios, and the coloration is due to an alga similar to Leptomitus.

B. brunneum, Schroeter.

Rods in a brown coloring matter in infusions of rotten corn.

Following the colored Microbacteria, I place two species of Bacterium recently described by Ray-Lankester and Warming.

B. rubescens, Ray-Lank., 1873.

Under this name Ray-Lankester has described 
some phases of development of Clathrocystis roseopersicina of Cohn. Now Cohn is inclined to regard the Monas vinosa, Ehrb. as the wandering cells of Clathrocystis. On the other hand Warming has described his : -

B. sulfuratum, Warming, 1876, giving it for synonymes, Monas vinosa, Ehrb.; M. erubescens, Ehrb.; M. Warmingii, Cohn; Rhabdomonas rosea, Cohn. It follows, then, that the Monas which we have described with the Spherobacteria should be referred to a Bacterium called sulphuratum by Warming, but which is also identical with B. rubescens of Ray-Lankester.

\section{Desmobacteria.}

Filiform bacteria, composed of elongated cylindrical articles, isolated, or in chains more or less extended, resulting from transverse division. Under this form they correspond to leptothrix, Auct. (differing from torula in that the filaments are not constricted at the point of junction of the articulations); filaments sometimes united in swarms, never in zoogloea. Movements and state of repose alternating and depending upon the presence or absence of oxygen, the reaction of the medium, and other conditions unknown. Some forms never exhibit movement. - Bacteridie of Davaine (Cohn).

We will only preserve in the Desmobacteria the genus ${ }^{-}$Bacillus, Cohn. The vibrios are rather allied to Spirillum because of their undulating filaments.

However, after the exposition of the different species of Bacillus, we will say something of three genera of colorless oscillatoriaceæ, which are nearly 
related to them, - the Leptothrix, Beggiatoa, and Crenothrix.

1. Fil. with indistinct articulations

Fil. very slender, short . . . Bactulos.

Fil. very slender, long . . . Leptothrix.

Fil. thick, broad . . . . Beggiatoa.

2. Fil. articulated distinctly . . . Crenothrix.

\section{g. Bacillus, Cohn.}

The bacilli are characterized by slender filaments, straight, short or of moderate length, rigid or flexible, endowed or not with motion.

One species is chromogene, the B. ruber of Cohn. Finally it is to this genus that we should refer the Amylobacter of Trécul.

B. subtilis, Cohn (Vibrio subtilis, Ehrb.; Ferment butyrique, Pasteur).

Filaments very slender and elongated, formed of a single cell having usually a length of $6 \mu$, or of two articles of which the total length is then $12 \mu$, or of three (length $16 \mu$ ), or of a greater number (sometimes as many as twenty, with a total length of 40 to 60 and $130 \mu$ ); thickness not measurable, well-defined movements of flexion, active or passive, and of translation forward or backward; reproduction by fission and by globular or oval spores developing themselves in the interior of the articles (Cohn). Is found in stagnant water.

Plays a great rôle in the butyric fermentation (Pasteur). This B. exists in rennet, can support a temperature of $105^{\circ}$, and live in a medium deprived of free oxygen, in which case it takes a form céphalée, containing persistent spores, 
which, when set free, give birth to other rods of Bacillus (Cohn).

B. anthracis, Cohn (Bactéridie charbonneuse, Davaine).

Species very similiar to the preceding, generally longer and always motionless; length 4 to 12 and even $50 \mu$, thickness, scarcely appreciable, 0.8 to $14 \mu$ (Bollinger).

The B. anthracis is developed in charbon (malignant pustule of man, sang de rate of sheep, maladie de sang of cattle, fièvre charbonneuse of horses), and in the rabbit, the rat, etc.; never in the dog, the cat, the birds, and coldblooded animals. It is found above all in the capillary vessels. Cultivated in suitable media, such as the aqueous humor of the eye of the ox, the Bacillus of anthrax develops spores in the interior of its filaments, which may germinate and reproduce rods (Koch).

According to recent observations not yet published, by cultivating the $B$. Anthracis in the blood of the dog, a development of veritable sporangia may be obtained, containing from three to six spores (Toussaint).

B. amylobacter, Van Tieghem (Amylobacter, Urocephalum and Clostridium Trécul).

B. occurring, like the preceding, under various forms, - in pointed cylindrical filaments of 6.6 to $26 \mu$ in length and $1.1 \mu$ in thickness, or in form of tadpole, with a spore in the terminal swelling, or of a spindle, with a spore in the middle. In fact, it does not differ from $B$. subtilis, except by the appear- 
ance of starch in its protoplasm at the end of the period of multiplication. These B. are sometimes endowed with movement (Nylander).

It develops in vegetable tissues, which fall into putrefaction, spontaneously according to Trécul, or introduced from without by a mechanism still unknown. This is the essential agent of vegetable putrefaction (Van Tieghem).

B. ulna, Cohn ( Vibrio bacillus, Ehrb.).

Filaments articulated, thick, and rigid, formed of one, two to four articles, straight or broken in zigzag; length of an article $10 \mu$, length of a filament of four articles $42 \mu$; slow movements of rotation and of progression.

Develops in various infusions of fresh or salt water. In certain cultivations, Cohn has seen large globules (spores?) form in the protoplasm. Warming believes that he has seen cilia.

B. ruber, Cohn.

Long rods, isolated or united in two or four, movement very active; in a red mucous substance, vermillion, developed upon grains of rice. Observed by Franck and Cohn.

Davaine has described five additional species of Bacteridies, which appear to be bacilli. They are:-

La Bacteridie intestinal.

Filaments straight, thick from 10 to $40 \mu$ in length. In the intestines of birds.

La B. du levain.

Filaments slender and short, of 10 to $20 \mu$, divided 
into two, sometimes three to four articles, identical with the B. of charbon (Davaine).

La B. glaireuse.

Filaments extremely slender, straight or elbowed; attaining $10 \mu$ in length.

La B. du vin tourné.

Filaments very slender, of variable length, flexible, indistinctly articulated.

La B. des infusions.

Filaments of 10 to $20 \mu$. In various infusions.

g. Leptothrix, Ktz.

The Leptothrix differ from Bacilli by their filaments being very long, adherent, very slender, and indistinctly articulated.

Their forms are numerous. The following are the principal:-

L. rigidula, Ktz.

Length 100 to $150 \mu$, diameter 1.3 to $1.9 \mu$. In stagnant water, adherent to other vegetables.

L. croespitosa, Ktz.

Length 100 to $200 \mu$, diameter 2.4 to $2.8 \mu$. Upon humid rocks.

L. brevissima, Ktz.

Length 75 to $100 \mu$, diameter 2.7 to $3.5 \mu$. In stagnant water.

L. pusilla, Rabh.

Length 60 to $70 \mu$, diameter 0.5 to $0.6 \mu$.

L. parasitica, Ktz.

Length 90 to $150 \mu$, diameter $1 \mu$.

$L$. radians Ktz., and $L$. spissa, Rabh.

Parasites upon marine algæ. 


\section{g. Beggiatoa, 'Trev.}

Filaments very slender, surrounded by mucous matter, rigid, having oscillatory movements. Protoplasm white, enclosing numerous granules, which recent observations have demonstrated to be crystalline sulphur (Cramer, Cohn).

The Beggiatoa are found most abundantly in thermal sulphur waters, where they constitute flocculi, which have been named Glairine, Barégine. They often live in water not containing free oxygen.

They play a great rôle in the elimination of sulphur and the disengagement of sulphuretted hydrogen in thermal waters.

Their principal species are:-

B. alba, Trev.

A whitish mucous mass enclosing colorless filaments, having a diameter of 3.5 to $4 \mu$. In most thermal and stagnant waters.

$B$. arachnoidea, Rabh.

Flocculi very minute, snow white, filaments as long as broad, -5.4 to $7 \mu$. In the thermal waters of Europe.

B. nivea, Rabh.; B. leptomitiformis, Trev., nearly related species, living in the same conditions.

Cohn and Warming have also described:-

B. mirabilis, Cohn, articles scarcely flexible, measuring 20 to $40 \mu$.

$B$. minima, Warming, a very small species, very flexible; length $40 \mu$, thickness 1.8 to $2 \mu$.

4. Spirobacteria.

This tribe includes the bacteria with undulating filaments, or filaments in spirals, more or less de- 
veloped, from the Vibrio rugula, which only presents a single curve in its centre, to certain species of Spirillum which have numerous turns of the spiral. In several species, cilia, or a flagellum, have recently been observed.

We divide them into three genera :-

Fil. short, slightly sinuous . . VIBrro.

Fil. short, spiral, rigid . . . Spirillum.

Fil. long, spiral, flexible. . . SpIRochete.

g. Vibrio, Auct. emend.

Body filiform, more or less distinctly articulated, always undulating, having serpentine movements. This genus forms the transition between the Desmobacteria and Spirillum "from which it cannot be separated" (Warming).

Fil. thick, with a single curve . . . V. RUGULA.

Fil. slender, with several undulations . V. sERPENs.

\section{V. rugula, Müller ( $V$. lineola, Duj. ex parte).}

Filament presenting in its centre a single curvature, feeble but distinct; length 8 to $16 \mu$. The shortest are slightly curved (=6 $\mu$ Warming), the larger, which may attain $17.6 \mu(\mathrm{Cohn}), 35 \mu$ (Warm.), are about to divide. Movements of rotation more or less rapid around their longer axis; of progression forward, giving then the idea of a serpentine movement: having a cilium (Warming).

V. rugula is commonly found in swarms, in infusions, in deposits upon the teeth, in intestinal matters (Leewenhoeck), in choleraic discharges (Pouchet). 
V. serpens, Müller.

Filament one half less in diameter than the preceding, rigid, annulate, having two or three regular undulations, at least two in the shortest; height of one turn of the undulations 8 to $12 \mu$, diameter 1 to $3 \mu$, total length 11 to $25 \mu$, thickness $0.7 \mu$; movements analogous to those of $B$. subtilis; having a cilium (Warm.).

In numerous swarms in infusions, river water, etc.

\section{g. Spirochæte, Ehrb.}

S. plicatilis, Ehrb.

Filament not extensible, twisted in a long helix, flexible, the turns of the spiral near together; susceptible of twisting upon its axis and of an undulatory movement; total length 130 to $200 \mu$.

Rare species; in infusions, stagnant water, sea-water, etc.

s. Obermeieri, Cohn.

Does not differ from the preceding, either in size, conformation, or in its movements, but by its habitat and physiological peculiarities.

In the blood of persons attacked by recurrent fever (Obermeier, 1872, Weigert, Bisch-Hirschfeld, etc.) during the period of access, never during the remission.

S. gigantea, Warming. Found upon the coasts of Denmark; thickness of body, $3 \mu$, height of spiral $25 \mu$, diameter 7 to $9 \mu$. 


\section{g. Spirillam, Ehrb.}

Filament spiral, rigid; turns of spiral short and regular.

S. tenue, Ehrb.

Filament slightly tortuous, three to four turns of the spiral; length and diameter of a single turn, 2 to $3 \mu$. When the filament has a turn and a half, it resembles an $\Omega$; the filaments of two to five turns have a length of 4 to $15 \mu$; spiral movement very rapid.

In infusions, etc.

S. undula, Ehrb. (Vibrio prolifer, Ehrb.)

Filament larger, turns of the spiral wider apart (from 3 to $5 \mu$ ); having usually one half a turn to one full turn, rarely one and a half, two, or three; length 8 to $10 \mu$, breadth $5 \mu$, thickness of filament $1.3 \mu$; having a very rapid spiral morement.

Fetid animal and vegetable infusions and running water.

The S. rufum, Pertz only differs from this by its reddish color.

S. volutans, Ehrb.

Filament large and thick, turns of spiral regular, well separated, and $13 \mu$ in height; number of turns two, three, and three and a half, rarely six and seven; total length 25 to $30 \mu$, thickness $1.5 \mu$, breadth $6.6 \mu$; movement sometimes rapid, sometimes motionless; a well-defined cilium, already seen by Ehrenberg (Cohn, Warming).

This giant of the bacteria is found in vegetable and animal infusions, in sea-water, and in fresh water. 

From Micr. Journ. Vol. XID, IN \$ Pl V

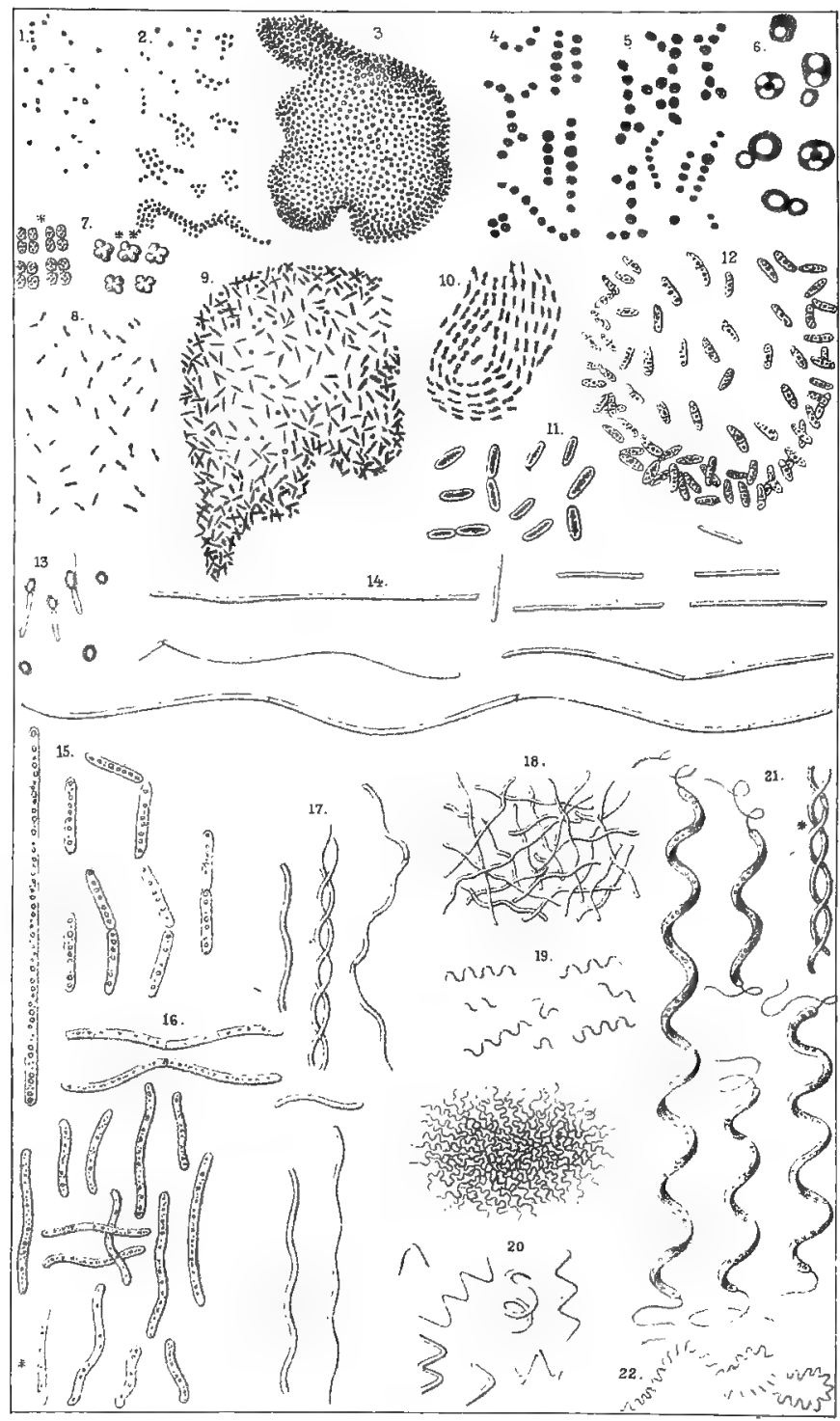

A.Molsel, lith. 


\section{PLATE $\nabla$. \\ From "Microscopical Journal."}

Fig. 1. - Micrococcus prodigiosus (Monas prodigiosa, Ehr.). Spherical bacteria of the red pigment, aggregated in pairs and in fours; the other pigment bacteria are not distinguishable with the microscope from this one.

Fig. 2. - Micrococcus vaccina. Spherical bacteria, from pock-lymph in a state of growth, aggregated in short four to eight-jointed straight or bent chains, and forming also irregular cell-masses.

FIG. 3.-Zoogløa-form of micrococcus, pellicles or mucous strata characterized by granule-like closely set spherules.

FIg. 4. - Rosary chain (Torula-form) of Micrococcus urece, from the urine.

Frg. 5. - Rosary-chain and yeast-like cell-masses from the white deposit of a solution of sugar of milk which had become sour.

Fxa. 6. - Saccharomyces glutinis (Cryptacoccus glutinis, Fersen.), a pullulating yeast which forms beautiful rosecolored patches on cooked potatoes.

Fig. 7. - Sarcina spec,* from the blood of a healthy man,** from the surface of a hen's egg grown over with Micrococcus luteus, forming yellow patches.

FIG. 8. - Bacterium termo, free motile form.

Fig. 9.-Zoogloa-form of Bacterium termo.

FIG. 10. - Bacterium-pellicle, formed by rod-shaped bacteria arranged one against the other in a linear fashion, from the surface of sour beer.

Fra. 11. - Bacterium lineola, free motile form.

FIG. 12. - Zooglœa-form of B. lineola.

FIG. 13. - Motile filamentous Bacteria, with a spherical, or elliptical highly refringent " head," perhaps developed from gonidia.

FIG. 14. - Bacillus subtilis, short cylinders and longer, very flexible motile filaments, some of which are in process of division.

Frg. 15. - Bacillus uha, single segments and longer threads, some breaking up into segments.

Fig. 16. - Vibrio rugula, single or in process of division.

Fia. 17. - Vibrio serpens, longer or shorter threads, some dividing into bits, at * two threads entwined.

Fig. 18. - "Swarm" of V. serpens, the threads felted.

FIG. 19. - Spirillum tenue, single and felted into "swarms."

Fia. 20. - Spirillum undula.

Fra. 21. - Spirillum volutans, * two spirals twisted around one another.

FIG. 22. - Spirochate plicatilis.

All the figures were drawn by Dr. Ferdinand Cohn with the immersion lens No. IX. of Hartnack Ocular III., representing a magnifying power of 650 diameters. 
M. Warning has recently described three new species found upon the coast of Denmark :-

Sp. violaceum, height 8 to $10 \mu$, diameter 1 to $1.5 \mu$, thickness 3 to $4 \mu$; a cilium at each extremity. $2.6 \mu$.

Sp. Rosenbergii, height of helix 6 to $7.5 \mu$, thickness 1.5 to

Sp. attenuatum, body very attenuated at the two extremities, without a cilium.

We give below some details concerning the other colorless Schizophytes :-

g. Sarcina, Goods.

The Sarcina, which it is useless to describe here, can be considered as bacteria in which the division occurs by two perpendicular partitions in such a manner that multiplication takes place in two directions.

Sarcina is very nearly allied to Merismopedia, from which it only differs by the absence of chlorophyll; its siliceous skeleton allies it with the diatoms.

g. Ascococcus, Billr.

Cells hyaline, small, globular, closely united in globular or oval families, irregularly lobed and lobulated, surrounded by a thick gelatinous envelope, cartilaginous, forming a soft membrane, flaky, easily separating.

A. Billrothi, Cohn.

Families in masses of 20 to $160 \mu$, surrounded by a thick membrane of $15 \mu$.

In a solution of tartaric acid exposed to the air.

g. Myconostoc, Cohn.

Filaments very slender, colorless, folded, rolled up in a mucous substance, united in very small globules. 
M. gregarium, Cohn.

Unique species found on the surface of a putrefying infusion.

g. Cladothrix, Cohn.

Filaments in form of leptothrix, very slender, colorless, not articulated, rigid or a little undulating, falsely dichotomous.

Cl. dichotoma, Cohn. In foul water.

g. Streptothrix, Cohn.

Filaments in form of leptothrix, very slender, colorless, not articulated, straight or slightly spiral, a little branched.

Str. Farsteri, Cohn.

In concretions in the lachrymal canal of man. 


\section{PLATE VI.}

From photo-micrographs made in Havana and New Orleans. Reproduced by permission of the National Board of Health.

FIG. 1. - Spirochate (plicatile?). From foul bilge-water, Havana, Sept. $1879 . \quad \times 1,4 \tilde{50}$ by Zeiss's ${ }_{1}^{1}$ in. objective.

Fig. 2. - Vibrios from water of harbor, Havana, near discharge of sewer, Aug., 1879. $\times 1,450$ diameters by Zeiss's $\frac{1}{18}$ in. objective.

Frg. 3. - Sarcina (sp. ?). From standing water in flower-vase, Lafayette cemetery, New Orleans, April, 1880. $\times 400$ diameters by Beck's $\frac{1}{5}$ in. objective.

FIG. 4.- Spirillum (volutans ?). From foul gutter-water, New Orleans, May, $1880 . \times 600$ diameters. 


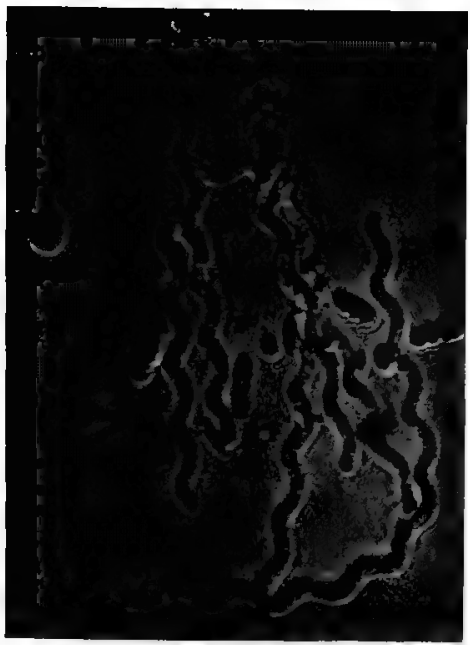

Fic: I.

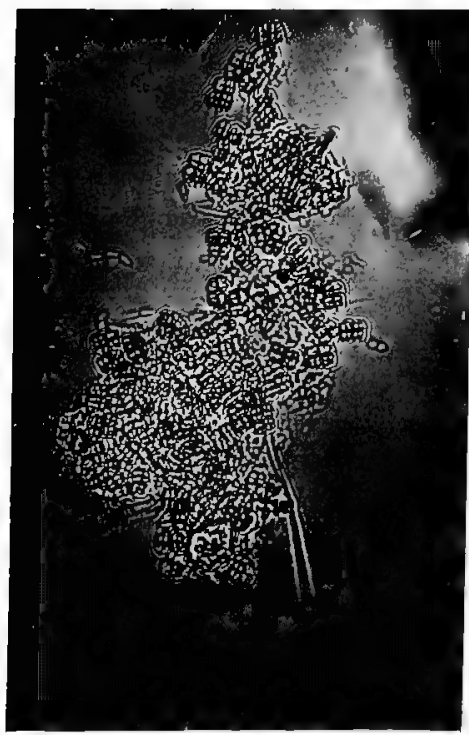

FIG. 3 .

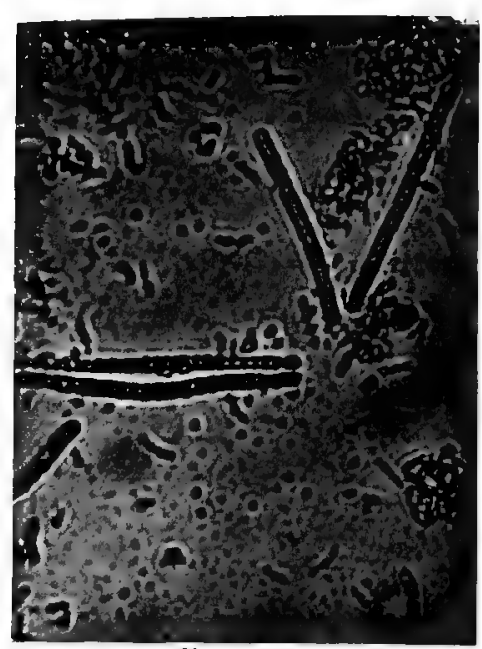

Fig. 2.

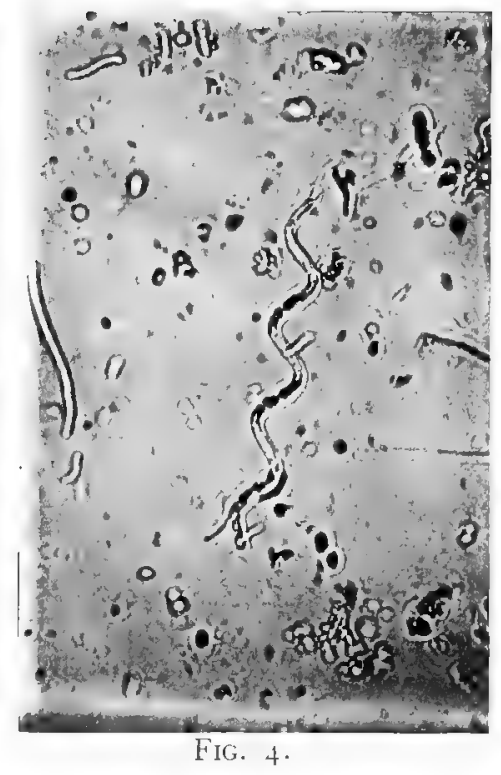





\section{PART SECOND.}

\section{PHYSIOLOGY OF THE BACTERIA.}

\section{- \\ CHAPTER I. \\ DEVELOPMENT OF THE BACTERIA.}

The bacteria are now known to us from a morphological point of view: let us proceed to study the life of these microscopic beings; first, from a general point of view, that is to say, by studying their functions of nutrition and reproduction, independently of the special characters impressed upon these functions by certain media; then by considering the relations which are established between the bacteria and the particular media in which they may be developed.

The bacteria are of all beings the most widely diffused. We meet them everywhere, - in the air, in water, upon the surface of solid bodies, in the interior of plants and animals. If we expose a transparent liquid containing traces of organic substances, we find after a short time that it has become clouded, and the microscope shows us that it contains myriads of these beings.

What is the source of these organisms so widely disseminated, and which develop so rapidly? This 


\section{PLATE VII.}

\section{Dissemination of the Bacteria.}

From photo-micrographs made in New Orleans. Copied by permission of the National Board of Health.

Frg. 1. - Spirillum (Sp.?) from water of salt marsh, near Salem, Mass. $\times 400$ diameters by Beck's $\frac{1}{5}$ in. objective.

FIG. 2. - Bacteria in distilled water (see note on page 107). $\times 1,000$ diameters by Zeiss's $\frac{1}{12}$ in. objective.

FIg. 3. - Leptothrix buccalis, epithelial cell, etc., from human mouth. $\times 1,000$ diameters by Zeiss's $\frac{1}{12}$ in. objective.

FIg. 4. - Bacteria from human foeces. $\times 1,500$ diameters by Zeiss's $\frac{1}{1}$ in. objective. 


\section{Plate VII.}

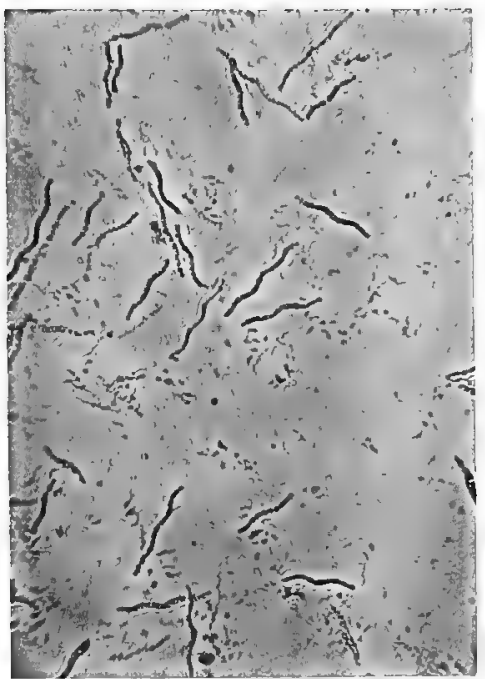

FIG. 1 .

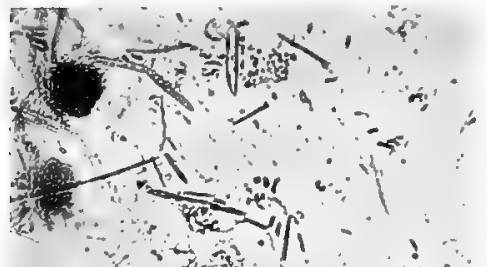

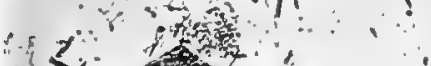

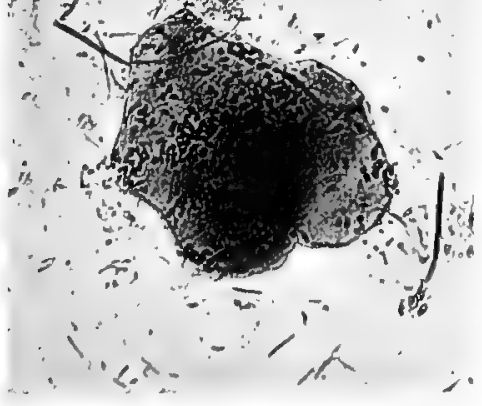

FIG. $\hat{\jmath}$.

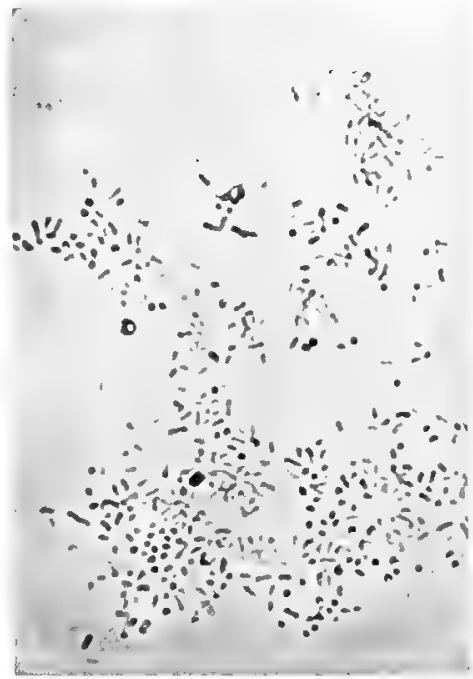

Fig. 2.

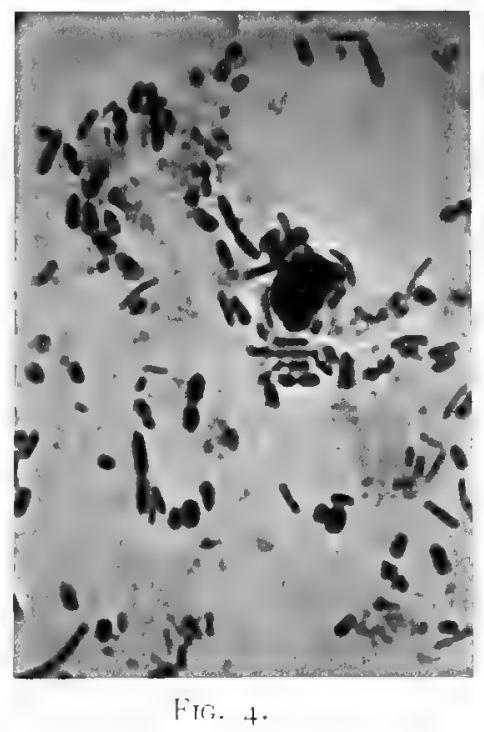



is the first question which presents itself, - a question which has given rise to long discussions, in the examination of which we shall only enter in order to give a short historical statement.

\section{§ 1. - OrigiN of the Bacteria.}

The origin of the bacteria, as of all the other inferior organisms, is conceived in three different manners : -

1. For some, these organisms are produced by heterogenesis; that is to say, by creation outright from mineral or organic substances (spontaneous generation).

2. According to others, they come directly from individuals like themselves, by one of the known modes of generation, - fission, spores, etc.

3. Finally it is believed that they are derived from organisms already existing, and are nothing more than different states or phases of development of known species, of which the life cycle is not yet discovered.

We will examine the latter hypothesis, which constitutes what is called polymorphism, when we speak of the phenomena of reproduction.

As to the two first, we will content ourselves with indicating the late works which have appeared for and against each; insisting above all upon the facts which relate to the proof of the presence of bacteria or their germs in the air, water, and liquids or tissues of the human organism, - blood, urine, etc. 
Heterogenesis. - Since the experiments of Pouchet and of his pupils, and the arguments given by MM. Trécul and Frémy, the last facts invoked in favor of heterogenesis are due to MM. Onimus, Servel, Bastian, etc.

M. Onimus contends that the "proto-organisms may be born in media, protected against the air, which contain albuminoid substances."

M. Martin sustains an analogous idea. According to him, the bacteria are derived from protein granules. According to Neusch, bacteria are produced in the interior of animal or vegetable cells without any lesion and without coming from the air. To demonstrate this he plunges divers fruits under water, in saline or acid liquids (phosphates, sulphates, carbonate of potassa, etc.), and he finds there bacteria; but, according to him, these are not living organisms, properly so called, but abnormal cellular vegetations.

M. Servel, decapitating some guinea-pigs, caused the heads, the livers, and the kidneys to fall into a solution of chromic acid, 1 to 100 . At the end of several days, the superficial parts were hardened; but the centre was softened, and filled with bacteria.

The presence of bacteria in eggs has several times been verified, and the heterogenists have hastened to draw an argument from this fact in favor of their theory. M. Gayon explains the appearance of these organisms in the eggs of birds by their presence in the normal state in the oviducts. 
Finally, Bastian, having succeeded in obtaining bacteria in liquids which he believes deprived of every germ, believes in their spontaneous generation. The following is a résumé of his experiment: Normal acid urine is brought to the boilingpoint, then a solution of potash (in sufficient quantity to neutralize the volume of urine employed) is also brought to the boiling-point; after cooling, the two liquids are mixed, and the whole placed in an oven at $50^{\circ}$. At the end of two or three days, bacteria are developed.

Pasteur points out three causes of error in the experiment of Bastian: 1. The germs may come from the urine; 2 . The germs may come from the solution of potash; 3. The germs may be furnished by the vessels employed in the experiment. In support of this criticism, Pasteur has made some similar experiments, guarding against these causes of error, and has not obtained bacteria.

Dissemination of Bacteria in Air and Water.

Air. - The experiment of Pasteur for gathering atmospheric germs is well known. He fixes a glass tube in an aperture made in a window-blind. The extremity of the tube, which communicates with the open air, is closed with a plug of cotton, to the other extremity is attached an aspirator. When the air has filtered through the cotton for some hours, this is examined, and is found to be filled with germs. 
Before Pasteur, Ehrenberg and G. de Claubry had already announced the presence in the air of the eggs of infusoria. Robin had also recognized that the atmosphere contains, in addition to all sorts of débris,.spores, pollen-grains, portions of insects, and rarely the eggs of. infusoria. More recently Maddox and Cunningham, by the aid of an aeroscope invented by the former, gathered numerous microbes, as well as bacteroid particles. Tyndall, by causing a ray of light to enter a darkened chamber, has rendered visible all these minute corpuscles. His researches show that the optical examination of air enables us to determine in an exact manner the presence or absence of germs.

Let us also mention the experiments recently made by Miquel in the park of Montsouris. This observer has found in the atmosphere a considerable number of germs. For the forms of which the diameter exceeds $2 \mu$, he has ascertained that "the average number of microbes in the air is feeble in winter and augments rapidly in spring, etc.; 2. That rain always diminishes the number of these microbes; 3. That rain-water introduced with the greatest precautions, into flasks with slender curved necks, first heated to destroy germs, rarely contains rotifers, etc., but always contains bacteria."

En résumé, the existence of germs can be demonstrated, 1, by direct research ; and 2, by cultivation. Direct research may be made by the optical examination of the air (method of Tyndall), the 
microscopic examination of dust (method followed by Marie-Davy, Tissandier), the examination of particles obtained by filtration, by gathering germs with an aeroscope, by condensation of atmospheric moisture upon refrigerating vases, etc. The cultivations consist in exposing to the air which is to be examined some liquids in which all pre-existing germs have been destroyed (Pasteur, Tyndall, etc.). This method has shown that liquids exposed in an atmosphere deprived of all germs does not undergo putrefaction, but this occurs as soon as the access of air not deprived of germs is permitted (Tyndall).

All of these methods give concordant results; deposits containing germs of various kinds are always obtained. But this objection presents itself to the mind: Do the bacteria obtained by cultivation exist in the atmosphere? or do they come from germs which have developed rapidly upon finding a favorable medium? From the experiments of Cohn, Miquel, etc., it is known that the atmosphere contains very few adult bacteria. Miquel in a recent communication says, in effect, that bacteria are rarely found in the air in a complete state, but rather under the form of shining points, difficult to distinguish directly one species from another. Are not these brilliant points Micrococci? In other terms, the air contains permanent spores, organisms which, as we shall see in speaking of the reproduction of the bacteria, develop at a certain period of the existence of the adult forms, in their interior, which escape from the sporogenous fila- 
ment, are drawn into the air by the evaporation of the liquid containing them, or, after dessication, by the winds. These spores are the point of departure of epidemic foci, and their extreme lightness explains how readily they are disseminated by the winds.

- Water. - Water contains considerable quantities of bacteria and especially of germs. Their presence in atmospheric water is established by the experiments of Lemaire and Gratiolet, — and after them by more recent observers, - by means of condensers filled with ice, and placed in the fields and for comparison in closed apartments. Rindfleisch has since expressed the opinion that the vapor of water does not contain spores or bacteria, and that telluric waters alone contain them; but Billroth, Cohn, and others have proved that Rindfleisch was too positive in his statement.

It is not surprising that telluric waters contain such a quantity of bacteria that their existence is admitted by all. The dust gathered upon the surface of stones, of leaves, of fruits, etc., shows upon microscopic examination an abundance of germs (Marié-Davy, Tissander); the washing of these objects and of the soil by the rain transports them into the rivers and from the rivers to the sea, which contains considerable quantities of them.

Thus, a drop of water from the Seine, according to Pasteur and Joubert, is always fecund, and may give birth to several species of bacteria. The distilled water of laboratories also contains germs, and 
these of so small a diameter that they pass through all filters. ${ }^{1}$ Cohn has proved that some are not arrested by a super position of sixteen filters. The only waters which do not contain them are those drawn from the very source of a spring.

\section{Dissemination of Bacteria in the Homan Organism.}

If bacteria are so generally disseminated in the great external media, it is not surprising that they are found on the surface of the human body and in the interior of the organs in communication with the exterior. But to account for their presence in the interior of organs we find ourselves in presence of two hypotheses: one admitting the spontaneous production of these organisms in the interior of the tissues, the second explaining it by the introduction through the membranes of the germs of bacteria from without.

I Having been directed by the National Board of Health' to make some experiments with a view to confrming or disproving the results of Klebs and Crudelli, who claim to have found the germ of malarial fevers in the atmosphere of the Pontine marshes near Rome (their Bacillus malarice), I aspirated ten gallons of air on the edge of a swamp in the vicinity of New Orleans, through 4 c.c. of distilled water. Upon examining this water with the microscope on the following morning, I was surprised to find a large number of actively moving bacteria and monads (Monas lens). To make sure that these really came from the air, I examined my distilled water, which had been standing in the laboratory for several weeks (in a bottle, corked, but occasionally opened as distilled water was required) and found the same forms present in considerable numbers, not so numerous, however, as in the water through which swamp air had been drawn. As the germs were present in the distilled water, I presume that the passing of air through it for several hours, and the organic matter contained in it, favored the development and multiplication of these micro-organisms. Subsequent experiments with freshly distilled water gave very different results as to the number of organisms found. See fig. 2, plate vii. - G. M. S. 
In truth, the cutaneous surfaces are penetrated with difficulty by germs, although the hairs upon the surface of the body serve to collect them. The short hairs in the nares prevent, to some extent, the atmospheric germs from penetrating into the bronchi, but this protection is not sufficient; and, notwithstanding the mucus of the nasal fossæ and of the pharynx, they may be found in the alveoli of the lungs, if we may believe Rindfleisch and Eberth. Do the bacteria pass into the blood? They may be transported in food and drink into the alimentary canal, where an elevated temperature, the presence of saliva, etc., favor their development. On the other hand, the acid secretions of the stomach, the bile, and the pancreatic juice moderate, if they do not prevent, the multiplication of these organisms.

The presence of bacteria in normal blood and urine, or their occasional entrance into these fluids, are important questions, which have induced many contradictory researches, but which are not yet definitely settled. ${ }^{1}$

1 "If there is any organism in the blood of yellow-fever demonstrable by the highest powers of the microscope as at present perfected, the photo-micrographs taken in Havana should show it. No such organism is shown in any preparation photographed immediately after collection. But in certain specimens kept under observation in culture cells, hyphomycetous fungi and spherical bacteria made their appearance after an interval of from one to seven days. The appearance of these organisms was, however, exceptional; and in several specimens taken from the same individual at the same time, it occurred that in one or two a certain fungus made its appearance, and in others it did not. This fact shows that the method employed cannot be depended upon for the exclusion of atmospheric germs, but does not affect the value of the result in the considerable number of instances in which no development of organisms occurred 


\section{Two kinds of researches have been undertaken} for the purpose of discovering germs in normal blood. The direct method, or microscopic examination, has given results very much disputed. The blood contains, indeed, a considerable number of little granules, of which the nature is doubtful, and which it is difficult to distinguish from Micrococcus. Thus, while Lüders asserts that normal blood contains germs, or spores, which only await a favorable alteration in the fluid in order to develop themselves, Rindfleisch formally denies their existence.

\section{The indirect method, which consists in cultivat-}

in culture cells in which blood, in a moist state was kept under daily observation for a week or more.

"The method employed seemed the only one practicable for obtaining blood from a large number of individuals without inflieting unwarrantable pain and disturbance upon the sick. It was as follows: One of the patient's fingers was carefully washed with a wet towel (wet sometimes with alcohol and at others with water), and a puncture was made just back of the matrix of the nail with a small triangular-pointed trocar from hypodermic syringe case. As quickly as possible a number of thin glass covers were applied to the drop of blood which flowed. And these were then inverted over shallow cells in clean glass slips, being attached usually by a circle of white zinc cement. In dry preparations, which are most suitable for photography, the small drop of blood was spread upon the thin glass cover by means of the end of a glass slip.

"The thin glass covers were taken from a bottle of alcohol, and cleaned immediately before using; and usually the glass slips were heated shortly before applying the covers, for the purpose of destroying any atmospheric germs which might have lodged upon them. These precautions were not, however, sufficient to prevent the inoculation of certain specimens by germs floating in the atmosphere (Penicillium and micrococci); and in nearly every specimen the presence of epithelial cells, and occasionally a fibre of cotton or linen, gave evidence that under the circumstances such contamination was unavoidable. It is therefore believed that any organism developing in the blood of yellow-fever, or of other diseases collected by the method described, or by any similar method, can have no great significance, unless it is found to develop as a rule (not occasionally) in the blood of patients suffering from the dis- 
ing normal blood in flasks perfectly closed, has also given some favorable results, such as those of Hensen, Tiegel, Billroth, and Nedvedsky, and some unfavorable results, as those of Luiders and Pasteur. According to Nedvedsky, the blood " contains germs capable of undergoing in it, under certain circumstances, an ulterior development: these are the Hémococcos." If these germs do not give birth, normally, to bacteria, it is because the blood is as injurious to them as the most advanced stages of putrefaction (Billroth). If this hypothesis is true, it explains several embarrassing facts, such as the existence of micrococci in the pus of

ease in question, and is proved by comparative tests not to develop in the blood of healthy individuals, obtained at the same time and by the same method.

"Tried by this test, it must be admitted that certain fungi and groups of micrococci, shown in photographs taken from specimens of yellowfever blood collected at the military hospital and preserved in culture cells, cannot reasonably be supposed to be peculiar to or to have any causal relation to this disease."- Preliminary Report of Havana Commission to National Bourd of Health.

In subsequent observations upon the blood of malarial fever, of syphilis, and of leprosy, I have sometimes obtained a development of micrococci in culture cells where all possible precautions as to the exclusion of atmospheric germs had been taken, and in one case have seen the development of Penicillium in another of Sarcina. The last observation is, so far as I know unique, and I have still in my possession the culture-slide containing numerous masses of Sarcina, presenting the characteristic arrangement of the cells in fours. This slide was put up at the bedside of a patient suffering from intermittent fever in the Charity Hospital, New Orleans. Every precaution was taken to exclude atmospheric germs. The patient's finger was washed with absolute alcohol just before making the puncture from which the little drop of blood was obtained. The question as to whether in this and similar cases the germs of the organism which develops come from the atmosphere or pre-existed in the blood is one to which I propose to give special attention; and, after further experiment, I shall discuss it in my report to the National Board of Health. - G. M. S. 
closed abcesses, in cysts, in urine drawn from the bladder, etc.

\section{§ 2. - Nutrition and Respiration of the Bacteria.}

The bacteria, being organisms composed of a cell membrane of cellulose, and of protoplasmic contents, deprived of chlorophyll, must receive nutriment and respire in the same manner as all the colorless vegetables and all the inferior animals deprived of special apparatus, - that is to say, by endosmotic absorption.

Although the media in which the bacteria develop are various, yet, from the point of view of the nutritive function, they act everywhere according to the same laws. No matter in what medium they live, they must have water, nitrogen, carbon, and oxygen, as well as certain mineral salts which enter, but in quantities exceedingly minute, into the chemical constitution of all organized bodies.

Water. - This element is indispensable to the active life and development of the bacteria. Dessication arrests completely the movements of those which are mobile, and the functions of all the bacteria in general; but it does not kill them, at least if it be not prolonged beyond a certain time. The Micrococci of different kinds of virus are examples of the continued vitality of these organisms after dessication for a considerable time. 
The bacteria present in this respect numerous variations according to the species and the period of development which they have attained. In the state of permanent spores, they are extremely tenacious of vitality. They resist for a long time not only dessication, but a considerable elevation of temperature.

Among the bacteria, some are developed in liquids, - the greater number, - others upon damp surfaces. The former can live in fresh water, seawater, thermal waters, and the liquids of animal or vegetable organisms, etc. A surprising fact is, that the composition, so different, of fresh and sea water appears to have no influence upon the bacteria. We find in both all the species, from Bacterium termo to Spirillum volutans.

Nitrogen. - Pasteur has demonstrated that it is not necessary that the nitrogen which is to serve as nutriment to the bacteria should be in the form of albumen, but that these organisms can take possession of it in the form of ammonia.

In fact, in Pasteur's solution, composed as follows :- -

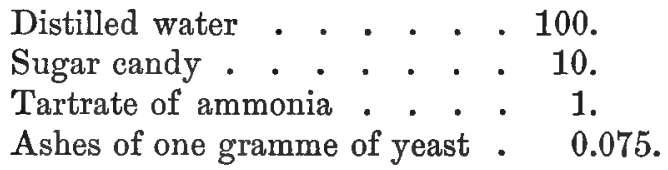

the bacteria increase sometimes with such rapidity that they interfere with the development of the alcoholic ferment. 
Cohn, in order to better observe the phenomena and to get rid of the moulds, which the cane-sugar caused to develop too rapidly, employed the following culture-fluid : -

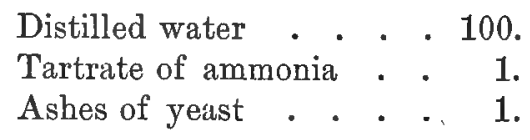

Bacteria develop in this fluid wonderfully, which proves that sugar is not indispensable to them.

One other solution often employed is that of Mayer. It has the advantage of not requiring the employment of ashes of yeast:-

Phosphate of potash . . $\cdot 0.1$ gramme.
Sulphate of magnesia..$\cdot 0.1 ~ "$
Tribasic phosphate of lime .0 .1 "
Distilled water . . . . . 20 c.c."

Cohn adds to this $0.2 \mathrm{gr}$. tartrate of ammonia.

En résumé, the bacteria can take nitrogen, which they need in order to form their protoplasm, either from albuminous compounds, which they decompose, as in putrefaction, or in the form of ammonia, or, perhaps, by borrowing it from nitric acid, but this last source is not well established (Cohn).

Carbon. - In addition to the sources common to other organisms, the bacteria can take this important element of their composition, under certain circumstances, from the organic acids. Thus, when we cultivate bacteria in a solution containing 
only tartrate of ammonia with a small quantity of mineral salts (phosphoric acid, potash, sulphuric acid, lime, and magnesia), they develop rapidly, taking their carbon from the tartaric acid.

Cohn has endeavored to ascertain if other organic acids could be assimilated by the bacteria. By making use of succinate of ammonia, or neutral acetate of ammonia, he has been able to cultivate these microphytes. Besides, as Pasteur had already experimented with solutions containing lartates, and in which bacteria had developed until the salt had completely disappeared, we may admit that the bacteria can assimilate the organic acids, - tartaric, succinic, acetic, and lactic; but tartaric acid seems to furnish the best alimentary solution.

Other substances containing carbon are also assimilated by the bacteria,_cane-sugar, milk-sugar, glycerine, and even cellulose (according to -Mitscherlich).

Cohn concludes, "that the bacteria multiply quite normally, and in great quantity, whenever they find the elements in solution which constitute ashes, and that they can take the carbon which they need from any organic substance containing it, and their nitrogen from ammonia, urea, and probably from nitric acid. The bacteria, then, resemble green plants, in that they assimilate nitrogen contained in their cells by taking it from ammonia compounds, which animals cannot do. They differ from green plants in that they cannot draw their carbon from carbonic acid, and only assimilate organic substances containing carbon, 
above all the hydrates of carbon and their derivatives ; and in this respect they resemble animals."

Absorption. - How are these various substances absorbed? The observations of Grimm, Hoffmann, de Seynes, etc., permit us to assure ourselves that these organisms absorb by endosmosis the substances upon which they are nourished.

Grimm, upon examining with the microscope some particles of lemon containing bacteria and spores of algæ, saw a certain number of the former gather around a spore, and fix themselves to it by one of their extremities. They did not penetrate it; but when they abandoned it, the spore had diminished in volume, and lost a portion of its contents, while the bacteria had taken a greenish color.

Hoffmann has seen that these little organisms, when placed in a solution of carmine or of fuschine, after a time are colored an intense red, while the mucus surrounding them remains colorless.

De Seynes, also, from his observations upon the vibrios which accompanied some colored filaments of Penicillium glaucum, believes that bacteria are susceptible of absorbing coloring matters from vegetables and from animals with which they are in contact.

Oxygen. - The rôle of oxygen in the life of the bacteria has given rise to numerous controversies. First, it seems a priori that the bacteria ought 
to act like all other living beings, and to respire like the other inferior organisms deprived of chlorophyll - that is to say by absorbing oxygen and eliminating carbonic acid. This is, indeed, the opinion of a great number of botanists. But, according to Pasteur, it is not so with the bacteria. When we examine what occurs in putrefaction, we find that at first certain species are developed (Monas crepusculum, Bacterium termo, etc.), which absorb all the oxygen dissolved in the liquid, and come to the surface where they form a thick veil; after this, other species of vibrioniens appear, which are developed in a medium entirely deprived of free oxygen, by borrowing this gas from the fermentable matters contained in the liquid. These chemical decompositions constitute putrefaction.

The first of these organisms, regarding the nature of which Pasteur has long been uncertain, are aérobies : they live in contact with the air, and have need of oxygen. The second, anaérobies, not only have no need of oxygen, but are killed by it.

These differences in the respiration of organisms belonging to the same group are not admitted by a great number of recent observers. Hoffmann, among others, says expressly: "These little beings cannot live without air, I should say without oxygen: if this gas is wanting, they cease to move and do not multiply at all. If a drop of liquid full of bacteria is placed upon a glass slip, then covered by a piece of thin glass, the active 
bacteria will all approach gradually to the margins of the cover; and it is there that at the end of several days, after the successive death of the greater number, some are still found endowed with life and movement. If a similar preparation is at the same time protected by an impermeable cement against dessication and against the introduction of atmospheric air, all movement among the bacteria will cease at the end of two minutes, provided, however, that no air bubble has been imprisoned with the liquid."

The influence of oxygen upon the life and development of bacteria is also very manifest in an experiment recently made, and not yet published, by Toussaint, who has been kind enough to communicate it to me.

In studying the development of the spores of Bacillus anthracis in the moist chamber of Ranvier, Toussaint has observed the following curious facts, which offer a striking analogy to those above mentioned, borrowed from Hoffmann. "The bacteria, which occupy the central portion of the moist chamber and which by reason of their situation receive very little oxygen from the groove, are soon arrested in their development; while those which occupy the borders are long and heaped up in immense numbers, those in the centre remain small, formed of two, four, or five articles, which are easily separated from each other; they soon cease to grow and are not transformed into spores."

Cohn is also as explicit. "There is no doubt," 
he says, "that the complete development of Bacillus, and above all reproduction by means of spores, is only made under the influence of free access of air."

We might explain the contradictory facts of Pasteur by admitting, with Cohn, that the appearance of different rôles played by the aérobies (Bacterium) and the ana'erobies (Bacillus) is simply due to a veritable struggle for existence which takes place between the microbacteria and the desmobacteria.

Action of Variods Agents upon the Bacteria.

In this paragraph I shall pass in review the action of temperature, of movement, and of various antiseptics.

Temperature. - It is very important to study the manner in which bacteria comport themselves under extreme variations of temperature. It is, indeed, upon the results furnished by these researches that a great part of the arguments opposed to the panspermatists by the heterogenists are based.

We shall consider the influence upon bacteria of moderate temperatures and of extremes above and below zero.

Moderate temperatures - that is to say those which are comprised between 25 and $40^{\circ}$ ( 77 to $104^{\circ}$ Fah.) - are generally favorable. The most favorable has been found to be $35^{\circ}$ (95 Fah.) (Onimus). 
The degree of resistance to extreme temperatures is very variable, according to the species. Thus, according to Frisch, a temperature of 45 to $50^{\circ}$ ( 113 to $122^{\circ}$ Fah.) is sufficient to kill B. termo, whilst $80^{\circ}\left(176^{\circ}\right.$ Fah.) does not kill the "Bactéridies" (Bacillus).

The permanent spores are especially remarkable by the tolerance which they possess for high temperatures. They have been subjected to $100^{\circ}$ (212 Fah.) (Schwann), $110^{\circ}$ (Pasteur) and even $130^{\circ}$ (Schrader) without losing their power of germinating.

We must, however, recognize that the results of the experimenters offer the greatest diversity, the result, according to Cohn, of the difficulty of obtaining an equable distribution of the heat in the media, which are generally bad conductors.

Cohn has arrived at the following conclusions as the result of numerous experiments made upon the Bacillus of hay infusions:-

1. At a temperature of 45 to $50^{\circ}\left(113\right.$ to $122^{\circ}$ Fah.) the Bacillus still multiplies rapidly, and forms as usual membranes and spores, while the other schizophytes existing in the infusion of hay are at this temperature incapable of multiplication.

2. At a temperature of 50 to $55^{\circ}$ (122 to $131^{\circ}$ Fah.) all reproduction and development of Bacillus ceases. It neither forms pellicles or spores; the filaments are killed, the spores, on the contrary, preserve, for a longer time (for at least seventeen hours) the property of germinating. 
3. While infusions of hay are generally sterilized by a temperature of $60^{\circ}$ ( $140^{\circ} \mathrm{Fah}$.) or more, prolonged during twenty-four hours, certain spores of Bacillus seem able to endure a temperature of 70 to $80^{\circ}$ (158 to $176^{\circ}$ Fah.) during three or four days without losing the power of germinating.

By some experiments made with refrigerating mixtures, Cohn has ascertained that the bacteria are not killed by very low temperatures, acting even during several hours, $-18^{\circ}$ for example $\left(0^{\circ}\right.$ Fah. $)$. But they are benumbed at a temperature of $0^{\circ}\left(32^{\circ} \mathrm{Fah}\right.$. $)$ and probably at a temperature a little higher, losing the power of movement and of reproduction, and consequently their action as ferments. They preserve, however, their capacity to resume their activity at a more elevated temperature.

Frisch has pushed the experiment still further than Cohn. By the evaporation of carbonic acid, he has produced as low a temperature as $-87^{\circ}$ ( $-123^{\circ}$ Fah.) in liquids containing bacteria, without destroying the vitality of these organisms, development having subsequently occurred of coc$\cos$ and of bacteria. Congelation, then, cannot serve to destroy the organized ferments.

Let us add, however, that if the passage to extreme temperatures is too sudden, there is then an alteration (destruction?) of these organisms (Schumacher).

Movement. - We would not have consecrated a paragraph to the action of movement upon 
bacteria, if Crova had not recently asserted that movements impressed upon a liquid containing bacteria completely arrests their development. This is an assertion in complete opposition to all that we know of the physiology of these organisms, and which it is difficult to reconcile with the fact that bacteria may develop even in the torrent of the circulation.

Compressed Air. - We have just seen the influence of air, and especially of oxygen, upon the bacteria. When this agent is in a certain state of tension, it acts in a different manner. M. Paul Bert has proved that under a tension of twentythree to twenty-four atmospheres all the putrefactive processes depending upon the development of vibrios cease to occur. Since, the same savant has found that the anatomical elements and even the red blood globules are killed by oxygen. These researches agree well enough with those of Grossmann and Mayerhauser upon the life of bacteria in gas. From their numerous experiments it appears that, under the influence of oxygen, there is an exaggeration of the activity of the bacteria; but if the oxygen is under a pressure of five to seven atmospheres, the bacteria live from six to twenty hours, then die, and cannot be resuscitated by atmospheric air.

Ozone causes a definite and almost instantaneous arrest of movement. 
Other gases studied by the same savants have given the following results:-

Hydrogen at first causes an acceleration of movement, which is maintained for several days; then movement becomes less active, and finally it ceases altogether.

Carbonic Acid. - Contrary to the facts stated by Pasteur, this agent was found to paralyze the bacteria, and reduced them to complete immobility. If the carbonic acid is displaced by oxygen, the bacteria resume their activity.

Chloroform. - This substance, according to the researches of Müntz, arrests the vital phenomena of organized ferments. Müntz uses this character in order to recognize the soluble ferments, upon which it has no action.

Boracic Acid. - Since the labors of Dumas, which have demonstrated that boracic acid kills the inferior organisms by depriving them of their oxygen, this substance has been employed in various circumstances as an antiseptic.

Sulphate of Quinine. - The action of quinine, either in the state of chlorhydrate or of sulphate, is not yet well established. The experiments of Binz, Manasseïn, Krovitsch, Bochefontaine, etc., have, in truth, given contradictory results.

Carbolic Acid. - The experiments of Manassein have demonstrated that $\frac{1}{2} \frac{1}{0}$ th per cent of car- 
bolic acid is sufficient to prevent all development of living beings. It is employed with success in anthrax, in the treatment of wounds, etc.

\section{$\S 3 .-$ Reproduction of the Bacterta.}

It is well established that the bacteria can multiply by fission, and reproduce themselves also by the formation of endogenous spores.

Fission. - The multiplication by fission consists in a transverse division of the cell. When a bacterium has attained nearly double its ordinary length, we see, in the larger species, that the protoplasm becomes clearer in the central portion, and a partition forms in the median line separating the contained protoplasm into two portions. The partition, at first very delicate, becomes thicker, divides into two, and the two articles separate.

This phenomenon is produced more or less quickly according to the nature of the medium, its richness in nutritive material, the temperature, etc. When the growth is rapid, the new cells form more quickly than they separate, and are arranged in chaplets. Very often we only find them in this form, in strings of two to four cells coupled together. In some forms the transverse division is preceded by constriction near the middle of the cell. Before the two new cells are separated, the bacterium in this case presents the appearance of a figure 8 , and seems to be a simple cell swollen at the two extremities. 
Under other circumstances, and probably in consequence of a mucus transformation of the walls of the mother cells, the new bacteria are enveloped by a mass of glutinous substance. We have described these masses under the name of $\mathrm{Zo}$ ogloea.

The conditions which favor multiplication by fission are, a certain degree of temperature and a sufficient quantity of nutritive material. The higher the temperature, the more rapid is the segmentation of the bacteria, the more rapid their multiplication, - that is to say, up to a certain limit, variable with the species and beyond which the bacteria are destroyed.

The multiplication decreases when the temperature is lower, and ceases entirely in the vicinity of $0^{\circ}\left(32^{\circ} \mathrm{Fah}\right.$.).

The influence of richness of nutriment is well seen in artificial cultivation. So long as the bacteria find the necessary aliment, in sufficient quantity, to form new protoplasm, they multiply with activity; but as soon as the organic matter is devoured, they cease to divide, fall to the bottom of the vessel, where they accumulate, motionless, and form a deposit more or less abundant.

The multiplication of the bacteria by binary fission has for result, if nothing occurs to interfere with the most favorable conditions, the invasion of the medium by an incredible number of these little beings, of which we can only form an idea by calculation.

"Let us suppose," says Cohn, " that a bacterium 
divides into two in the space of an hour, then in four at the end of a second hour, then in eight at the end of three hours, in twenty-four hours the number will already amount to more than sixteen millions and a half $(16,777,220)$; at the end of two days this bacterium will have multiplied to the incredible number of $281,500,000,000$; at the end of three days it will have furnished fortyseven trillions; at the end of about a week, a number which can only be represented by fifty-one figures.

"In order to render these numbers more comprehensible, let us seek the volume and the weight which may result from the multiplication of a single bacterium. The individuals of the most common species of rod-bacteria present the form of a short cylinder having a diameter of a thousandth of a millimeter, and in the vicinity of one five hundredth of a millimetre in length. Let us represent to ourselves a cubic measure of a millimetre. This measure would contain, according to what we have just said, $633,000,000$ of rod-bacteria without leaving any empty space. Now, at the end of twenty-four hours the bacteria coming from a single rod would occupy the fortieth part of a cubic millimeter; but at the end of the following day they would fill a space equal to 442,570 of these cubes, or about a half a litre. Let us admit that the space occupied by the sea is equal to two-thirds of the terrestrial surface, and that its mean depth is a mile, the capacity of the ocean will be $928,000,000$ of cubic miles. The multipli- 
cation being continued with the same conditions, the bacteria issuing from a single germ would fill the ocean in five days."

Reproduction by Spores. - The multiplication by fission, known to the earliest microscopists, has been until recently the only mode of propagation admitted by the authors. Thus M. de Lanessan, in the excellent article which he has devoted to the bacteria, says that the marvellous resources of modern science have not yet permitted us to recognize any other mode of propagation for these organisms.

However, M. Ch. Robin had already, in 1853, indicated the presence in Leptothrix buccalis of little round bodies, "which are perhaps spores." Pasteur has since, in 1865, recognized that "the vibrios of putrefaction and of butyric fermentation present a sort of ovule, or ovoid corpuscle, which refracts light strongly, either in the extremity or in the body of the articles." Later, the same savant, more explicitly, says clearly that these organisms have two modes of reproduction, - by fission and by interior spores ("noyaux").

Towards the same epoch, Hoffmann also pointed out a reproduction by free cellular formation in some bacteria. But we must come to the labors of Cohn, Billroth, and Koch, in order to find precise observations in this regard.

The formation of spores has been observed in Bacillus subtilis by Cohn, Bacillus anthracis by Koch, and in Bacillus Amylobacter by Van Tieghem. 



\section{Plate VIII.}

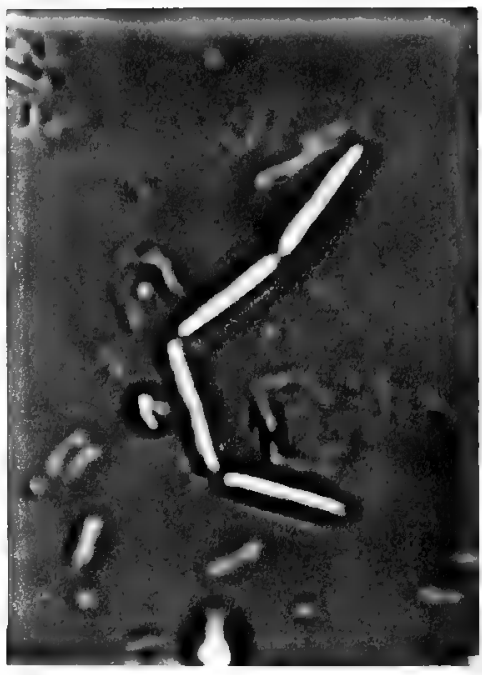

FIG. I.

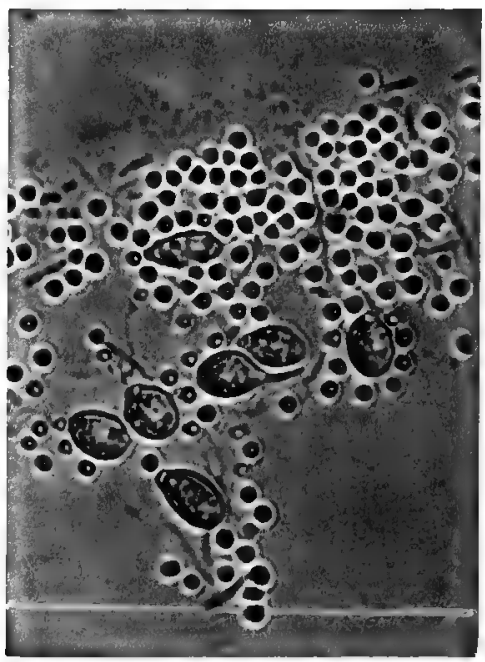

FIG. 3.

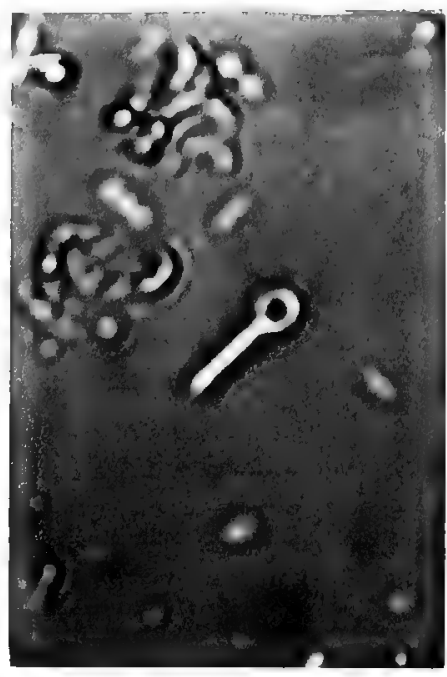

Fig. 2.

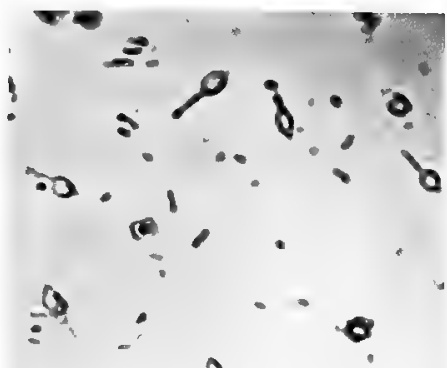

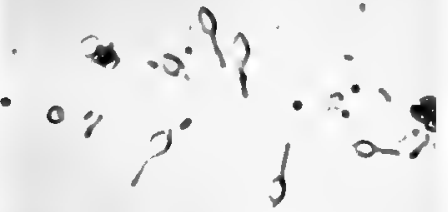

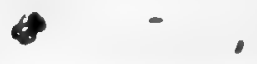

Fits. 4. 


\section{PLATE VIII. \\ Formation of Spores in Bacillus.}

From photo-micrographs made in Havana and in New Orleans. Reproduced by permission of the National Board of Health.

Frgs. 1 and 2. - Bacillus (ulna?) found in blood of yellow-fever patient (post-mortem) five days after collection. $\times 3,000$ diameters by Zeiss's $\frac{1}{18}$ in. objective.

FIG. 1. - Rods joined in leptothrix chain.

FIG. 2. - A single rod showing spore at one extremity.

Fig. 3. - Spores of Bacillus developed in rotten potato, New Orleans, April, 1880. $\times 1,500$ by Zeiss's ${ }_{1 \frac{1}{1}}^{\frac{1}{3}}$ in. objective. The large cells are some species of Saccharomycete, which was also present in the same specimen.

FIG. 4. - Development of bacilli from spores, from culture experiment with fish gelatine solution. $\times 1,500$ diameters by Zeiss's ${ }_{1}^{\frac{2}{8}}$ in. objective. 
Cohn, who had in his first publications refused to the bacteria the property of reproduction by spores, thinking that the facts observed by Hoffmann related to different beings, has verified the experiments of Koch upon the development of $B$. anthracis, and has himself demonstrated similar phenomena in $B$. subtilis.

In culture experiments made with infusion of hay, we see, at a certain moment, in the homogeneous filaments of the Bacilli very refractive corpuscles making their appearance. Each of them becomes a spore, oblong or in the form of a short filament, highly refractive, and with well-defined outlines. We find the spores arranged in a simple series in the filaments. As soon as the formation of spores has terminated, the filaments can generally no longer be distinguished, and one would say that the spores were completely free in the mucus; but their linear arrangement shows always that they are produced in the interior of filaments. Little by little these dissolve, being reduced to a fine powder; and the spores fall to the bottom of the liquid, where they are found in abundance. The germination of the spore does not seem to occur in the same medium; but if we take a spore from the deposit formed in an infusion of boiled hay, and transport it into a new infusion, we see the spore swell up, and a short tube form itself at one of its extremities: at this moment it resembles a bacterium with a head. Soon the very refractive body disappears, the tube stretches out into a short rod of Bacillus, com- 
mences to move, and becomes jointed by transverse division.

Koch, in cultivating the bacteria of charbon in aqueous humor from the eye of the ox, has observed some facts exactly similar, both as to production of spores in linear series in the filaments of Bacillus anthracis and as to the germination of the spore and the birth of a new rod.

According to Van Tieghem, the development of Amylobacter is as follows: "The development of a Bacillus includes four successive periods. In the first, the body, cylindrical and slender, recently developed from a spore, stretches out rapidly, and is partitioned; the articles soon separate (B. subtilis), or remain united in long filaments (B. anthracis). This is the stage of growth and multiplication, two things which at bottom are but one.

"Secondly, the articles previously formed, having ceased to elongate and divide, increase sensibly in magnitude, becoming the seat of interior chemical transformations; and this increase in size operates according to circumstances, in three different manners, with some intermediate forms. Sometimes it occurs uniformly throughout the length of the article, which remains cylindrical; sometimes it is localized, either at one extremity, which is swollen like a tadpole, or in the middle of the article, which swells to a spindle shape. This is the stage of enlargement, or of nutrition, solitary and simultaneous, which prepares the following state.

"In the third period or phase of reproduction 
there is formed in each article so nourished a spherical or ovoid spore, homogeneous, highly refractive, having a dark outline. At the same time, the protoplasm which occupies the rest of the cavity disappears little by little, and is replaced by a hyaline liquid, which separates the spore from the membrane; this dissolves in its turn, and finally the spore is set at liberty. If the article is swollen in tadpole shape, it is in the terminal swelling that the spore has birth; if it is spindle-shaped, it is near the middle; if it is cylindrical, it may be at any point whatever, but is usually near one extremity. The spore when set free germinates under favorable circumstances. At a point where its circumference becomes pale, it gives out a little tube slightly more slender than itself, which elongates rapidly and divides. This fourth period of development or germinative phase brings us back to our point of departure."

Sporangia. - Finally, not only do the bacteria develop spores in the interior of their filaments, slightly modified in form, but we may also observe the formation of a veritable sporangium containing many spores. The unpublished observations of M. Touissant, Professor of Physiology in the Veterinary School of Toulouse, give this result, which he has kindly communicated to me.

In cultivating spores of the bacteria of charbon in the serum of the blood of the dog, under the microscope, in the warm chamber of Ranvier, Toussaint has seen the filaments take a transverse 
diameter almost double the ordinary diameter, then the protoplasm of the filament to gather together at certain points, - a fact clearly made out, as in the parts where the protoplasm was wanting the bacteria had lost all refractive power. Finally, at a later period the points occupied by the condensed protoplasm augment considerably in volume, and form some ovoid organs more or less elongated, or swollen into a ball, or in the form of a gourd at one extremity. In the interior of these sporangia, from three to six spores afterward form, clearly defined and highly refractive; then, finally, by breaking up of the membranous envelope the spores become free.

Toussaint has also followed in the same apparatus - moist and warm chamber of Ranvier - the mode of germination of the spores. The following are the most important facts :-

The spores are at first highly refractive and animated by brownien movements; at the end of half an hour to an hour, at a temperature of 37 to $40^{\circ}$, in urine, aqueous humor, or serum, the spores lose their refractive power, and their brownien movements cease almost entirely; then the spore assumes an aspect slightly granular, it becomes elongated in the direction of its greatest diameter (they are oval). After two hours of cultivation, the bacterium has two or three times the dimensions of the primitive spore; the elongation makes rapid progress, and four to six hours from the commencement of the cultivation, some may 
be found to occupy the entire field of the microscope. From this moment the phenomena which occur differ according to the conditions in which the bacteria are placed. Upon the edge of the air-groove in the moist chamber, the bacteria develop very rapidly, forming an interlaced mass; and in sixteen to eighteen hours, spores may be seen to appear in their interior, - above all, if the preparation has been exposed to light. Often, in this case, the transverse partitions of the filament cannot be seen. If, on the contrary, the bacterium has not been exposed to light, the spores are a longer time in showing themselves (ten or twelve hours more), and almost always division of the filament precedes their formation. In that case, a spore usually appears at each end of the segment in such a manner that the spores belonging to two successive segments are nearer to each other than those in the same segment. Often, also, a spore aborts in a segment (Toussaint).

We have seen above, in speaking of the respiration of bacteria, that the same observer has noted in the course of his experiments some phenomena proving the evident influence of oxygen upon the development of Bacillus. It is the same for the formation of spores. And upon this point Toussaint makes the very just remark that the phenomena occur in a different manner in culture experiments and in the human organism. In charbon, the bacteria never form spores. They remain always relatively short, even in the points where they form extra-vascular masses, and where conse- 
quently we cannot invoke the movements of the liquid in order to explain their division. The bacteria of charbon, then, take but little oxygen from the tissues: they do not vegetate luxuriantly in the organism; and certainly, if we judge by a calculation necessarily approximative, their development is seven or eight times less rapid than in the strongly oxygenated serum of culture experiments (Toussaint).

Polymorphism. - The spores of which we have traced the genesis constitute those germs of which the origin has for a long time been misunderstood, - those permanent spores or durable spores (Dauersporen), thus called because of their remarkable degree of resistance to temperature, desiccation, and all the agents which kill adult bacteria or arrest their development.

These "organs" are disseminated in great numbers in various media under the form of little rounded corpuscles absolutely similar to the micrococci from which it is absolutely impossible to differentiate them. It is, indeed, very probable that the greater part, if not all of these organisms, are the spores of filiform bacteria.

In the impossibility of recognizing these forms so nearly related, of referring them to such or such a determined organism, the attempt has been made to cultivate them, in order to follow their development. We have just seen the results of this cultivation for the Bacillus; but, in the hands of the greater number of experimenters, the re- 
sults of such culture experiments are far from being so certain. Not having succeeded in removing them completely from the invasion of foreign germs, the greater number have seen the most diverse forms develop themselves, and from this have inferred the most remarkable transformations.

Thus, Hallier pretends to have observed the transformation of Micrococcus into various fungi, such as Mucors, Ustilago, etc. The M. of vaccinia comes from Torula rufescens, which is itself a phase of development of Ustilago carbo; the M. of human variola is derived from a fungus having sporangia and pycnidia, related to Stemphylium sporidesmium; that of the variola of animals from Cladosporium (Pleospora) herbarum; the M. of the blood of scarlatina belongs to the g. Tilletia; those of glanders and of syphilis from a Coniothecium, etc. In the same way Letzerich has referred the M. of diphtheria to another Tilletia, the $T$. diphtherica.

The transformation of bacteria into "levîres" (yeast fungi), and these into Penicillium, has been admitted by Hallier, Trécul, and others. But the researches of Brefeld and de Seynes have shown us that this is far from being demonstrated; indeed, in his numerous cultivations, de Seynes has never been able to verify such an affiliation; and Nägeli in his turn bas never been able to obtain a transformation of schizomycetes into budding fungi.

It is the same as regards the transformation of 
bacteria into moulds and mildews. In some recent cultivations of moulds, made with care, Nägeli has never observed the formation of schizomycetes, and reciprocally. Are we not permitted to believe, now that we know of the formation of sporangia among the bacteria, that the microscopists who sustain a polymorphism so extended, have taken these organs, of which they have not been able to follow exactly the development, for the sporangia of Mucorini? This explanation is the more admissible as Trécul has seen the bacteria "swell up, and transform themselves separately," a phenomenon quite identical to that observed by Toussaint.

En résumé. The only change of form well demonstrated in the present state of science, and the only one which can be compared to natural polymorphism, such as it exists in a great number of fungi, consists in the transformation of spores into Bacteria, Bacteridia, Vibrios, etc., and in the different modes of grouping that the cells of bacteria take in becoming zoogloea, mycoderma, leptothrix, etc. To go further would be to lack prudence and scientific criticism. 


\section{CHAPTER II.}

\section{DEVELOPMENT OF THE BACTERIA IN DIFFERENT MEDIA.}

IN studying the conditions of life and of development of bacteria in the different media, natural and artificial, in which they are met, we will consider the actions which they determine (or that they accompany) as particular cases of their nutrition and of their reproduction. We will constantly take, then, their normal physiology as our point of departure; and we will try to explain in this way the phenomena, so diverse, with which they are associated, - fermentations, putrefactions, contagion of infectious maladies, etc.

It is especially interesting to study the rôle of bacteria in non-nitrogenized chemical media, where they accompany the phenomena called fermentation, properly so called; in nitrogenized media, vegetable or animal, which they transform, as a result of special fermentations, which constitute putrefaction; in the human organism, where they accompany frequently, if not always, the development of certain affections having special characters. This will be the object of so many paragraphs. 


\section{§ 1.-Rôle of Bacteria in Fermentations.}

We say that a liquid is fermenting whenever modifications occur in its chemical constitution, as a result of the nutrition of organized beings.

Two kinds of fermentation are commonly distinguished. In the first group (false fermentations) are arranged those which are produced by soluble quarternary substances (diastase, soluble ferments) secreted by living cells, from which they may be separated in order to study their action upon fermentable liquids. This action is comparable to that of certain mineral acids, which operate in the same manner, either by the breaking up of molecules with addition of water or by the phenomena of hydration. Veritable chemical reagents, when these substances are once precipitated from their solutions, purified and dried, they preserve their properties indefinitely. A sufficient elevation of temperature seems to destroy the edifice of their molecule; for they lose all their specific power after having been subjected to a temperature more or less elevated, but always inferior to $100^{\circ}\left(212^{\circ} \mathrm{Fah}\right.$.).

In the second group (true fermentations) are joined all the phenomena of chemical modification which appear intimately united to the development of inferior organisms, - algæ or fungi (figured ferments). Compressed oxygen by killing these ferments, and chloroform by suspending their vital functions, arrest the progress of these fermentations, while the same agents do not mod- 
ify at all the action of soluble ferments. According to Dumas, borax has, on the contrary, the property of entirely destroying the activity of soluble ferments without absolutely preventing certain true fermentations,-for example, the alcoholic fermentation of glucose. We will see further on that this property of borax has been utilized in the treatment of catarrh of the bladder and of certain virulent affections.

Although at first view these two groups of phenomena seem very different, they may, however, be compared the one with the other. Without speaking of the ammoniacal fermentation of urine, which, as we shall shortly see, may be arranged in either of these groups, we may admit that the only difference between these two series of chemical modifications consists in the fact that in one case the true fermentations being the last term in the interior nutrition of the cell have their seat in the interior of the cell itself; while in the other the first terms of nutrition are always extra-cellular phenomena, having for effect, as Cl. Bernard has shown, to render assimilable or diffusible in the interior of the organism the aliment necessary to the development of every organized being (transformation of starch into glucose, of sugar into glucose, emulsion of fats, liquefaction of albuminoid substances).

The study, from a chemical point of view, of these phenomena of nutrition, of these fermentations, since such is their name, has not yet made much progress, and it would be difficult to make a rational classification of them in the present state 
of our knowledge. I will not then seek to classify them, but will content myself with describing them successively, commencing with the best known. I shall only speak of the fermentations caused by the development of bacteria, leaving, consequently, the fermentation which has been best studied, - the alcoholic. I adopt the following order: -

1. Acetic fermentation of alcohol.

2. Ammoniacal fermentation of urine.

3. Lactic, viscous, and butyric fermentations of sugar.

4. Putrefaction, or nitrification.

Acetic fermentation. - The transformation of wine into vinegar is a phenomenon long known and utilized. From a chemical point of view, this transformation is due to oxydation of the alcohol. The following formula represents this reaction :-

$$
\mathrm{C}^{2} \mathrm{H}^{6} \mathrm{O}+\mathrm{O}^{2}=\mathrm{C}^{2} \mathrm{H}^{4} \mathrm{O}^{2}+\mathrm{H}^{2} \mathrm{O} .
$$

The agent of this oxydation is a micro-organism called Mycoderma aceti. It belongs to the group of the microbacteria, and we have already given the botanical description of it (page 83); but its development presents some interesting peculiarities which we think it proper to indicate in the language of M. Duclaux:-

"These little beings reproduce themselves with such rapidity that by placing an imperceptible germ upon the surface of a liquid contained in a vat having a surface of one square metre, we may see it covered, in from twenty-four to forty-eight hours, with a uniform velvety veil. If we suppose 
that there are three thousand cells in a square millimetre, which is below the truth, this will give for the vat three hundred milliards of cells produced in a very short time."

"The Mycodermi aceti is not always the same. Usually it forms upon the surface of a liquid a soft-looking veil, smooth at first, then wrinkled, which is with difficulty submerged and moistened. If a glass rod is plunged into the liquid, it pierces this veil ; and when it is withdrawn, a portion remains attached to the rod; and the opening made immediately disappears, being occupied by the veil which seems never to have room enough in which to extend itself. In some unpublished experiments I have frequently observed another form of veil, dryer, finer, and sometimes showing prismatic colors. This veil does not wrinkle, but is covered with crossed undulations, having sharp edges, which recall the surface of a honeycomb. Sowed upon the surface of various liquids, it reproduces itself identically, and it is difficult not to consider it a different form of the preceding. Finally, I have also met a species of mycoderma producing well-developed veils, but having scarcely any acetifying power, and reproducing itself with this character."

"It is difficult to distinguish these forms the one from the other, by the microscope, because of their minuteness. We may, however, say that the second which I have described is sensibly smaller than the first, and the third more attenuated than either of the others. However, the differences are feeble." This veil is called the mother of vinegar. The 
liquid in which this mycoderma is cultivated should be a little acid, containing one-half per cent of acetic acid, for example. Under these conditions the Mycoderma vini (a species of Saccharomycete), the formation of which should be avoided, finds conditions unfavorable to its existence. Indeed, this second organism, commonly called flowers of wine, has an action quite different from that of the Mycoderma aceti. It consumes the alcohol entirely, transforming it into water and carbonic acid: it also consumes the acetic acid. We must sow the $M$. aceti, if we do not wish to see the $M$. vini develop in its place, as the germs of the latter seem more widely diffused in the air.

In order that the acetification may occur, the oxygen of the air is necessary. Once submerged, the $M$. aceti develops, but no longer produces acetic acid. It is even probable that it consumes the acetic acid already formed, reducing it to the state of water and carbonic acid. It is the same when, developing upon the surface, it has transformed all the alcohol. "In effect, it is not then arrested in its work; and without changing form or mode of action, it carries the oxygen of the air to the acetic acid which it has produced, transforming it into carbonic acid and water. If we add some alcohol to the liquid, the phenomena change: the 'acid is respected, and the alcohol is transformed anew into acetic acid" (Duclaux). According to the experiments of Mayer, the maximum of acetifying power is obtained between $20^{\circ}$ and $30^{\circ}\left(68^{\circ}\right.$ to $86^{\circ}$ Fah. $)$, and this power is lost below $10^{\circ}\left(50^{\circ}\right.$ Fah.) and above $35^{\circ}$ ( $95^{\circ}$ Fah.). 
Ammoniacal Fermentation of Urine. - When urine is freely exposed to the air, we perceive at the end of a short time that it has become strongly ammoniacal. The urea is transformed into carbonate of ammonia by the addition of water:-

$$
\mathrm{CO}\left(\mathrm{NH}^{2}\right)^{2}+\mathrm{H}^{2} \mathrm{O} \doteq \mathrm{CO}^{2}+2 \mathrm{NH}^{3} .
$$

Müller suspected that the deposit of altered urine, of which Jacquemart had already recognized the particular activity, was an organized ferment, but this was only an induction drawn from the analogy with beer yeast. Pasteur showed that this sediment is formed of a mass of spherical globules, united in chaplets, which he considers the agent of ammoniacal fermentation. These globules are Micrococcus urece, Cohn, which we have already described (page 75).

This bacterium lives in the interior of the liquid, and not on the surface like the Mycoderma aceti. Acidity is an obstacle to its development; alkalinity, on the contrary, favors it within certain limits. Van Tieghem has even seen the fermentation continue until the liquid contained thirteen per cent of carbonate of ammonia.

What is the mechanism of this fermentation?

M. Musculus has shown that we may obtain from altered urine a soluble ferment upon adding to it highly-concentrated alcohol: a precipitate is formed, which may be filtered and dried. This precipitate, not at all organized, transforms urea into carbonate of ammonia. A temperature of $80^{\circ}$ (176 Fah.) destroys it. This diastase appears, 
then, to be a secretion of the Micrococcus urece; and perhaps the rôle of the bacteria is limited, in the phenomena of fermentation, to the formation of this secretion alone. The ammoniacal transformation of urine would consequently enter into the group of fermentations by the varieties of diastase.

According to Arnold Hiller, if carbolic acid be added to urine, it does not become alkaline; on the contrary, the acidity is even augmented, and that notwithstanding a considerable number of bacteria which develop in it. Has the carbolic acid killed the Micrococcus urece, leaving the field free to other organisms capable of living in an acid medium, and of producing other transformations of the constituents of the urine? In the memoir which we here cite, the author, resuscitating the ancient opinion of Liebig, wishes to demonstrate that the decomposition of dead organic matters, and putrefaction in general, are phenomena purely chemical, - these decompositions being determined by the presence of organic substances, themselves undergoing transformations.

We will not stop to consider these views, long since refuted: the experiments upon which they are founded are easily criticised. It is sufficient for me to say that they are in formal opposition with all the observations contained in modern works upon this question.

It is especially in relation to ammoniacal fermentation that the question of spontaneous generation has been discussed. We have already seen the results arrived at, and will not return to 
this subject. Let us, however, mention before closing an interesting work by MM. Cazeneuve and Livon, in which are reported some experiments which prove that urine never ferments in a healthy bladder.

Lactic, Butyric, and Viscous Fermentations of Sugars. - Saccharine liquids, left to themselves, are susceptible of divers fermentations, which may occur separately or simultaneously. Those which have been best studied are three, - the lactic, the butyric, and the viscous fermentations. We will describe them successively.

1. Lactic Fermentation. - Under the probable influence of a bacterium (ferment lactique of Pasteur) glucose and the substances susceptible of furnishing it, such as mannite, malic acid, etc., are transformed into lactic acid.

From a chemical point of view, there is in this nothing more than a molecular change, lactic acid having the same composition as glucose.

Taken in mass, the lactic ferment resembles beer-yeast; its consistence is, however, a little more viscous, and its color more gray. But under the microscope, the aspect is very different, as we have seen in describing Bacterium lineola.

An interesting point concerning this fermentation is the action of acids upon the bacteria which produce it (presumably). As soon as the medium becomes acid, even by the lactic acid produced, the transformation is arrested. It resumes its course, if chalk or carbonate of soda is added to the liquid. 
The most suitable temperature seems to be $35^{\circ}$ (95 Fah.).

We know but little about this fermentation. "It merits, however, to be better studied. It is this which causes the spontaneous coagulation of milk: sugar of milk is transformed into lactic acid, which coagulates the caseine. We often see it occur in beef juice or in sour starch water; it must play a part in the formation of sour krout, and intervenes very certainly, and perhaps more than the alcoholic fermentation, in the preparation of bread. Finally, it very easily invades beer, which of our domestic drinks is most exposed, because of its slight acidity, to become the seat of this fermentation. All of these facts render it interesting, so much the more as it is rarely exempt from complication, and is frequently accompanied, for example, by a commencement of butyric fermentation, far more disagreeable in its products" (Duclaux).

2. Butyric Fermentation. - This is, in fact, always preceded by a lactic transformation, and it is by an ulterior modification that the lactic acid produces the butyric acid. The organism which accompanies it is a bacterium very nearly allied to Bacillus subtilis, Cohn.

The reaction represented by the phenomena, from a chemical point of view, is the following:-

$$
\underbrace{2 \mathrm{C}^{3} \mathrm{H}^{6} \mathrm{O}^{8}}_{\text {lactic ac. }}=\underbrace{\mathrm{C}^{4} \mathrm{H}^{8} \mathrm{O}^{2}}_{\text {butyric ac. }}+2 \mathrm{CO}^{2}+\mathrm{H}^{4}
$$


According to Pasteur the butyric ferment belongs to his class of anaérobies.

'This fermentation resembles putrefaction in a great many particulars. Indeed some authors include it under the same head.

3. Viscous Fermentation. - Wines often change so that they contain a mucilaginous substance and mannite. This viscous matter has the same composition as gum or dextrine $\left(\mathrm{C}^{6} \mathrm{H}^{10} \mathrm{O}^{5}\right)$; at the same time it disengages carbonic acid.

In the fermenting liquid, we find an organism which is not yet sufficiently studied. "There are chaplets of little spherical bodies, of which the diameter varies sensibly, according to the kind of wine attacked by this malady (Pasteur).

Pasteur has proposed the following formula:-

$$
\begin{gathered}
25\left(\mathrm{C}^{12} \mathrm{H}^{22} \mathrm{O}^{11}\right)+25 \mathrm{H}^{2} \mathrm{O}= \\
\underset{\text { mannite. }}{\left.24\left(\mathrm{C}^{6} \mathrm{H}^{14} \mathrm{O}^{6}\right)+12 \mathrm{CO}^{2}+12 \mathrm{C}^{12} \mathrm{H}^{20} \mathrm{O}^{10}\right)}+ \\
\text { gum. }
\end{gathered}
$$

which represents the phenomena well enough as it usually occurs. There is produced in the vicinity of 51.09 of mannite and 45.5 of gum for one hundred parts of sugar. But sometimes the gum exceeds the mannite in quantity. In this case, according to Pasteur, we can always verify in the liquid the presence of a larger ferment of a different nature; and the same author adds that, perhaps, in this case the increased production of gum results from the presence of this second ferment, which transforms the sugar only into gum, without 
any correlative formation of mannite. But this ferment has never been isolated. M. Monoyer has explained the variation in the proportion of gum in another manner (see his thesis for the doctorate in medicine, Strasburg, 1862).

White wines are more subject than red wines to this fermentation, called graisse des vins. According to M. François, the absence of tannin in the white wines is the cause of this disease, and it may be prevented by adding this substance. This remedy is even very highly appreciated in champagne, according to Pasteur. What is the exact action of the tannin upon the gummy ferment? The only means of knowing is by cultivating this ferment in a state of purity and treating it with this agent.

We have united together the lactic, butyric, and viscous ferments, because all three manifest themselves in the same liquids, - wines, beer, sweetened water, etc.; and because they have for effect the transformation of glucose. We ought to say a word here of some other inferior organisms, perhaps bacteria, observed also in the same liquids, but which have not been as well studied. Not only are they not known systematically, but we do not know precisely what is their chemical action upon the elements of the medium which nourishes them. I shall only enumerate them.

1. Ferment of Turned Beer (Pasteur). — "These are rods or filaments, simple or articulated into chains of variable length, of about $1 \mu$ diameter. 
A high power shows them divided into a series of shorter rods, scarcely born, not yet mobile at the articulations, which are scarcely indicated."

2. Micrococcus of a beer, having a particular acidity, distinct from that of beer piqué, having an acetic odor. "It consists of grains resembling little spherical points jointed by pairs or in fours square" (Pasteur), etc.

§ 2. - Rôle of the Bacteria in Putrefaction aNd Nitrification.

While in the fermentations which we have just passed rapidly in review, we have always been able to study, at least summarily, the chemical action of the different organisms, we are now about to find ourselves in presence of phenomena far more complex. We will have to consider a great number of these vegetables at work, without its being possible to assign to each its rôle, or to say what is its function. The agent of the nitric fermentation has not as yet even been seen, and it is only by analogy that we class this nitrification with the true fermentations.

It is not only because of the obscurity which still exists in regard to a great number of peculiarities of these two phenomena, that we have united them in the same study. From the point of view of the circulation upon the surface of our globe of the elements essential to the constitution of organisms, they play an analogous rôle, although opposite the one to the other. 
Let us consider, for example, nitrogen in plants. This element, of which the atmosphere is the reservoir, does not enter directly into combination, as does oxygen, with the other elements which with it are to constitute the immediate principles of the tissues. The chemical properties of nitrogen may be characterized in two words, - great resistance to entering into combination when it is free, and great facility, on the contrary, in passing from one combination to another when once it has associated itself with other elements.

The circulation of nitrogen in a state of combination upon the surface of the globe is also an interesting question of general physics, as well as the circulation of carbonic acid, of water, and of the air.

Let us seek to sketch the march of this circulation.

Whence comes the ammonia which is found in the sea, in the clouds which come to us from equatorial regions, in the dust of the air? The only known source is the fermentation of organic matters out of reach of the oxygen of the air. It is to this sort of fermentation that we owe the formation of peat and the immense masses of combustible minerals which have formed during nearly all the geological periods. We see this sort of fermentation develop itself when we expose an organic liquid to the air, but only in the inferior part of the liquid, the oxygen which is dissolved near the surface being arrested in the superficial zone, where a very different fermentation occurs. 
The latter is essentially oxidizing; the material is almost completely burnt, forming water and carbonic acid; at the inferior part, on the contrary, a reduction is produced so energetic that hydrogen is disengaged. The metallic sulphates are there transformed into sulphites, and even crystals of sulphur are sometimes found (see the history of the Beggiatoa, page 91).

We see then the source of the ammonia, which, distributed upon the soil by the winds and the rains, becomes a powerful fertilizer. Now, vegetables do not absorb nitrogen under the form of ammonia, but under the form of nitric acid. How is this transformation of ammonia into nitric acid effected? The observations of Erdmann, Mensel, and T. Phipson show that in the phenomena of destructive putrefaction, nitric acid, far from being produced, is on the contrary reduced to the state of nitrous acid; on the other hand, Th. Schloesing and A. Müntz conclude from their experiments that in the putrefactions essentially oxidizing produced by Penicillum glaucum, Aspergillus niger, Mucor mucedo, etc., there is no formation of nitric acid. But, according to these authors, nitrification is a special phenomenon which takes place in every soil sufficiently loose to permit a free circulation of air, and of which the agent is a micro-organism. This organism has not yet been perceived, it is true; and it is evident that it would be difficult to seek and observe, because of its peculiar situation.

But the action of chloroform upon nitrification tends to prove that the agent of this process is 
truly an organized ferment. Indeed, chloroform, this anæsthetic, suspends nitrification, and seems even to kill the ferment.

Leaving, then, this phenomenon, but little known, we may distinguish in the agents of putrefaction, or more generally of fermentation, two groups of micro-organisms, - one oxidizing, the other reducing.

The first are observed upon the surface of liquids undergoing putrefaction. We may distinguish a great number of forms, - Bacterium termo, Monas crepusculum, Spirillum, etc. We ought also to include Mycoderma aceti, which, like the others, vegetates on the surface of liquids, and a great number of organisms of which we cannot speak here.

The second are met, on the contrary, in the interior of liquids or of fermentable bodies; they are analogous to the butyric and lactic ferments, and perhaps to the other agents of diseases of wine and beer previously enumerated.

En résumé, the little beings which we have been considering have an important rôle: they cause the return of dead organic matter to the atmosphere and to water.

"Without them, organic matter, even exposed to the air, would not be destroyed or would be transformed with extreme slowness, in consequence of a slow combustion produced by oxygen. With them, on the contrary, its destruction takes a rapid march and becomes complete. If, then, the equilibrium is maintained between living nature 
and dead nature, if the air has always the same composition, if the waters are always equally fertilizing, it is thanks to the infinitely minute agents of fermentation and putrefaction" (Duclaux).

But the rôle of bacteria is not limited to this. "They invade also the living organism," says Duclaux, "and bring in their attack this double character of infinite smallness in the apparent means and powerful destructive energy in the results. From this source come diseases of which medicine, not long since, did not know the cause, and which she only commences to refer to their veritable origin. For those who are au courant with the first steps which she has made in this new line of research, with the fecundity of her first glimpses, with the richness of her first results, it is not doubtful that she will soon succeed in demonstrating the parasitic nature of the gravest epidemic maladies."

\section{§ 3. - Rôle of the Bacteria in Contagious Maladies and Virulent Affections.}

We shall first pass in review the different affections in which the presence of bacteria has been indicated, whether they have been given as the cause of the malady or considered as simple epiphenomena.

Septicemia. - According to the hypothesis of Borsieri and of Gaspard upon the nature of septic blood, Sédillot demonstrated by some very conclusive experiments that the infective power is due to formed elements (des éléments figurés). 

Plate [X

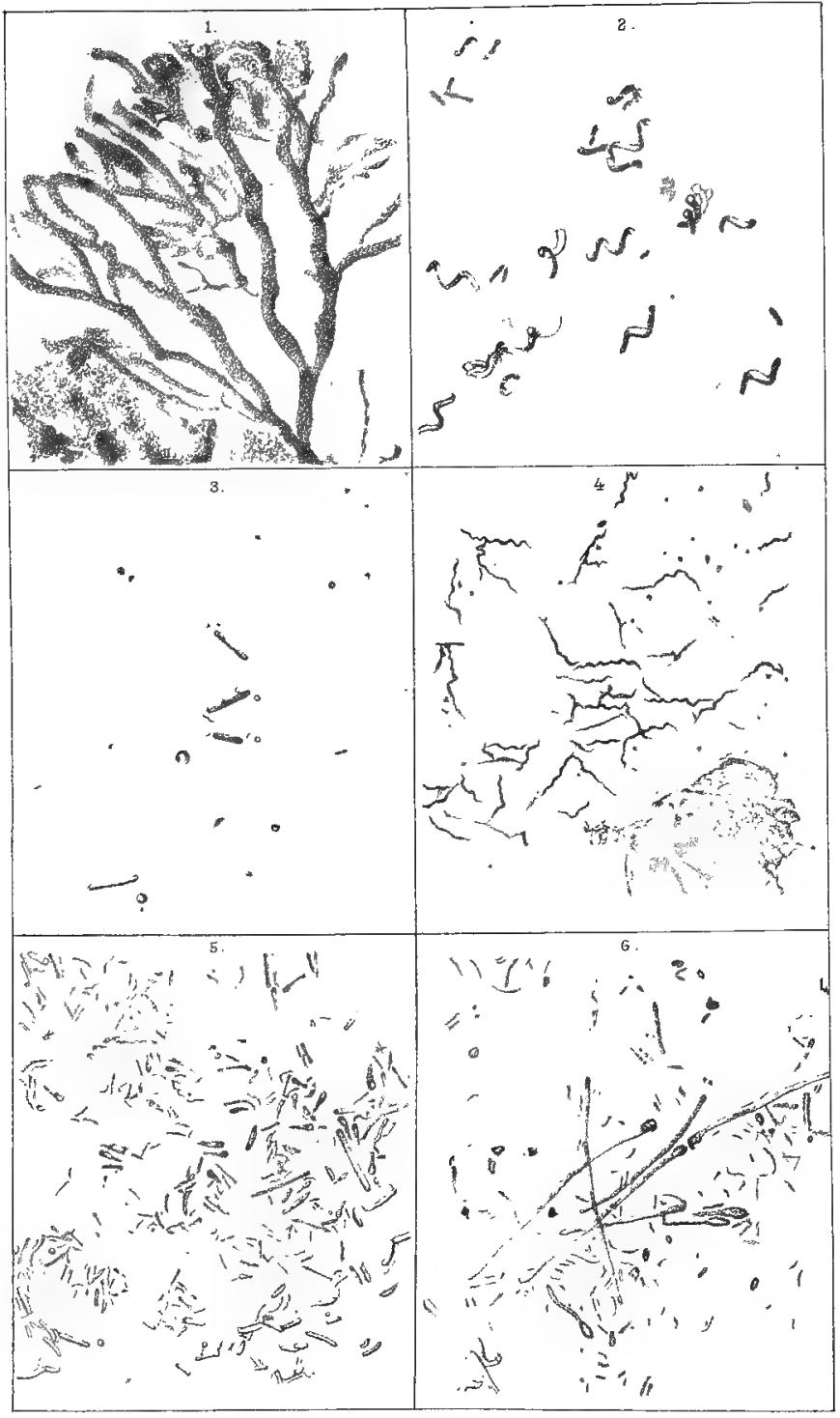

A.Mersel,itth. 


\section{PLATE IX.}

Copied from photographs by Koch in Cohn's "Beiträge zur Biologie der Pflanzen," Bd. II., Heft 3.

FIg 1. - Zooglcea ramigera from fluid containing rotting algæ. $\times 200$ by Seibert's immersion objective No. $7 .^{1}$

Fra. 2. - Spirillum undula. $\times 500$.

FrG. 3. - Bacillus (subtilis?), from hay infusion, showing flagella. $\times 500$.

FIG. 4. - Spirochate from human mouth, resembling the Spirochwete Obermeieri of relapsing fever. $\times 500$.

FIG. 5. - Bacilli, with spores from rotten onion. $\times 500$.

Frg. 6. - Bacilli, with spores from surface of rotten potato. $\times 500$.

1 A higher power (500) shows that these branches are made up of oval bacteria 
The first experiments of Davaine brought him to the following conclusions: "The effects of putrefying substances do not go beyond the animal into which these substances are injected. The toxic agent of putrid matters does not regenerate itself. Putrefaction acts upon the animal economy as a poison." The first opinion should have for it the authority of Robin. Already in 1864, Leplat and Jaillart, after a series of inoculations made with septic blood, arrived at deductions analogous to those of Robin. At the same epoch, Billroth and Weber, having injected the gases of putrefaction, expressed the opinion that the septic agent was of a molecular nature (particulate). Bergmann, of Dorpat, admitted as contagious agent an azotized substance, not organized, resisting alcohol and ether at a temperature of $100^{\circ}$, and passing through filters. This theory was identical with that of Panum. It is to Pasteur that the honor belongs of having first affirmed the parasitic nature of septicemia. This communication was followed by confirmatory ex-' periments by Coze and Feltz. These experimenters also proved that the bacteria of putrid blood do not possess the property of traversing the epithelium, and that "the infectious element gains in passing through similar organisms." In 1868, Davaine, changing his first opinion, admitted the presence of bacteria in the blood of animals which die of septicemia. Hallier of Jena and Béchamp of Montpelier also believe in the presence of a micro-organism, - Micrococcus for Hallier, Microzyma for Béchamp. 
Coze and Feltz, in their work, have demonstrated the constant presence of bacteria in the blood of animals dead from septicemia. This correlation has driven them to admit that "there is a direct relation between the infections accidents and the little foreign organisms which play, in the blood, the rôle of ferments, and reproduce themselves." New researches confirmatory of the first have been communicated to the Academy by the same authors. Opposed to these conclusions upon the bacterial origin of septicemia, some experiments have recently appeared in England, then in Berlin, which weaken them. Zuelzer, struck by the analogy which exists between septicemia and intoxication by atropine (dilatation of pupils, intestinal paralysis, acceleration of heart's action), has sought for the presence of an alkaloid by the method of Stas. In collaboration with Sonnenschein, he has succeeded in discovering it. Bacteria cultivated artificially, and introduced in considerable quantity into the mouth, under the skin, and into the vessels of various animals, have never seemed to him to produce septic accidents: But the scene changes as soon as an addition is made to the injected matters of two to five centigr. of neutral sulphate of atropia. The period of incubation always lasted from nine to twelve days. The same year, Riemschneider deduced from his observations the same result, and confirmed thus the similarity between atropine and sepsine. The bacterial origin of septicenia received, however, a new support from the experiments of Vulpian. 
Having injected into a rabbit two drops of blood from a man who died of pulmonary gangrene, the animal died at the end of twenty hours. Numerous bacteria were found in its vessels. The liquid extract of these, injected into other rabbits produced death in twenty-four hours, and the same parasites were observed in their blood.

According to Henrot the bacteria penetrate by the pulmonary mucus membrane, and only act in contact with blood rendered "phlogogène" by pus. There is then a necessity for two producing causes. In support of his opinion the author cites the following experiment. $\mathrm{He}$ injects into the jugular of two rabbits a mixture of distilled water and pus, for the purpose of rendering the blood "phlogogène;" in two others he injects pulverized coral suspended in water. One of the first rabbits and one of the second, placed in a pure air, resist perfectly. The two others are subjected to emanations from putrefying "anatomical" fragments. The rabbit into which pus had been injected died in three days, the second was still living at the end of a month.

Cavafy admits the presence of bacteria in septic liquids, but does not regard them as the efficient cause of the thromboses following inoculations. According to Moritz Traube and Gschleiden, living organisms into which one injects blood containing a great quantity of the bacteria of putrefaction, do not suffer any durable harm from the injections.' At the end of

1 I have injected various liquids containing bacteria into the circulation of dogs and into the cellular tissue of rabbits, but have never seen any serious results follow such injections. - G. M. S. 
twenty-four hours, the arterial blood drawn from a rabbit into which one and one half.centimeters of liquid containing bacteria had been injected, can be preserved (by protecting it from exterior germs) during several months, without presenting traces of putrefaction. The bacteria then are dead in the living organism. Nevertheless, the living blood is powerless to resist beyond a certain point. These results seem difficult to reconcile with those which Feltz has reached as the result of new researches with the toxic principle of putrid blood. Compressed air passed through a septic liquid has no influence upon its toxic properties or upon the minute beings contained in it: there is simply a diminished movement of the vibrios. In a vacuum the toxic power is diminished: the Cocco-bacteria and bacteria become motionless, the vibrios and spiral bacteria lose their activity, but the smallest forms are not killed. W. Moxon and J. F. Goodhart have recognized the presence of bacteria in the blood and in the inflamed tissues of septicemic patients. According to Virchow, also, the active agent is a bacterium which, injected, with or without putrid liquid, produces death by septic intoxication.

Livon and Zuelzer have never observed any symptom of putrid infection to follow injections of these micro-organisms into the blood.

In presence of so many divergent opinions, each supported by scientific authorities, we do not feel justified in adopting any definite conclusion. 
The experiments of Coze and Feltz, however, as well as those which confirm them, lead us to consider the constant presence of bacteria in putrid blood as a great probability in favor of the parasitic genesis of septicemia.

There is a variety of septicemia which presents the closest resemblance to that of which we have just spoken; namely, puerperal septicemia. The preceding researches, with their consequences, are all applicable to this form of septicemia, and explain to us its nature. This manner of seeing seems to us justified by the labors of Orth of Bonn, according to which the lymph and the blood contain Micrococci in considerable numbers. Klebs has verified the presence of the same parasites in the putrid infection consecutive to gun-shot wounds. Like the preceding authors, Birsch-Hirschfeld recognizes in the liquids of septicemia the presence of Micrococci, and does not admit any other parasites.

Charbon. - A malady in which the influence of inferior organisms has been especially sought is charbon.

We will examine successively the results furnished by experimental pathology and by clinical observation, and will finish by a general discussion of the nature of charbon.

Although this affection has been known and studied from the highest antiquity, and was described by Chabert (1782), Gilbert (1795), and many others, its parasitic nature has not long been 
known. Let us note, however, that Fuchs, Brauell, Pollender, and Delafond, had remarked some corpuscles in the blood of animals attacked with charbon. Prof. Delafond made, twenty years ago, some researches, which he communicated to the Central Society of Veterinary Medicine, upon the rods of sang du rate. Davaine, who had observed, with Roger, the presence of rods in the blood of charbon as early as 1850, did not attach any importance to the fact. After the work of Pasteur in 1861, he resumed his researches and the results which he obtained were communicated to the Academy of Sciences the 27th of July and the 10th of August, 1863, then the 22d of August, 1864. His experiments established the fact that the blood of animals attacked with charbon contains organisms (éléments figurés), and that, injected into a healthy animal, it kills it by reproducing the same symptoms. There remained a step to make, to prove that the bacteria alone possessed the infective power, even in epidemic cases. Notwithstanding the labors of Signol (1864) corroborating his discoveries, Davaine did not fail to find opponents. Leplat and Jaillard made known the results of their experiments, according to which the bacteria were not the cause of sang de rate. In 1867, Bouley and Sanson, and in 1870, Baillet, studied the nature of the malady known under the name of mal de montagne.

Klebs, in Switzerland, having, with Tiegel of the Pathological Institute of Berne, made some negative injections with filtered blood (of char- 
bon) demonstrated thus that the disease was truly due to the solid particles; but he could not, as he did, affirm that the bacteria alone were endowed with virulent power, for he included at the same time all the other solid elements (fibrine, globules), and could not therefore eliminate the granulations of a virus other than the bacteria. Klebs does not believe that the bacteria cause death by asphyxia. This view is also sustained by Recklinghausen and Waldeyer, who believe that death results from embolism : according to Burdon-Sanderson, on the contrary, this is not the case.

The observations and experiments up to this time demonstrated that the blood of charbon would transmit the disease. Davaine had said that the bacteria constituted the condition sine qua non of the development of these diseases, but he had against him the experiments of Leplat and Jaillard. Besides, as he injected at the same time other corpuscles figurées, it was difficult to prove that they went for nothing in the production of charbon. Finally, this theory could not explain certain endemics (pastures in Auvergne). One could truly say, with Burden-Sanderson, that the virulent element can exist in two forms, - one fugitive (bacteria), one permanent, unknown. The point was to demonstrate it. This is what Koch has done. Having taken some bacteria, he cultivated them in urine, or the aqueous humor of the eye of a horse, and remarked that they underwent a certain elongation, then presented brilliant points of condensation which became free; injected 
into the blood of sheep and of rabbits, these corpuscles produced death with the symptoms of charbon, and the blood of the animals presented numerous bacteria. The appearance of spores in the liquid under cultivation, containing bacteria, occurs in twenty-four hours at $35^{\circ}\left(95^{\circ} \mathrm{Fah}\right.$.), in three days at $18^{\circ}$; above $45^{\circ}$ and below $12^{\circ}$ it is no longer possible. Once produced these spores resist putrefaction, desiccation, and alternation of hurnidity and dryness, during several years. On the contrary, the adult form of the Bacillus anthracis dies under the influence of putrefaction and of oscillations of temperature. It has not seemed to develop itself in the dog, the cat, birds, and cold-blooded animals. The immunity which these enjoy has recently been the object of a study by Pasteur, Joubert, and Chamberlain. Believing that it might be attributed to their temperature, incompatible with the life of the bacteria, they have refrigerated a fowl, and have ascertained that it lost this immunity. Besides, by placing the infected animal in an oven at $30^{\circ}\left(86^{\circ}\right.$ Fah. $)$ they have seen the temperature come back rapidly to the normal and the symptoms of charbon to recede.

T'he labors, then, of Koch add an additional element of probability in favor of the parasitic theory. They show us the existence of an organism which we would be able to invoke as the cause of spontaneous epizootics.

All these results Cohn of Breslau has obtained upon repeating the experiments of his compatriot. 
In France, Toussaint commenced, March 21, 1875 , a series of successful inoculations upon rabbits, with blood obtained from the spleen and an abdominal tumor of a sheep which had died of the mal du rate. These specimens had been sent to Chauveau by Joly, veterinary surgeon at Gien. Having preserved some blood in the air, Toussaint remarked, as Davaine had done and as Koch had observed, that putrefaction kills the Bacillus; enclosed in a close vessel, it succumbs as soon as oxygen is wanting, which occurs sooner when the temperature is elevated.

It was upon the presentation of these results to the Academy of Sciences that Cohn expressed the opinion that charbon is not due to a bacterium, but to a special virus. If the filtered blood does not act, it is because the filter, at the same time, retains the virus.

Pasteur, in his letter of Aug. 18, 1877, replies that a virus would be impotent to resist the numerous cultivations endured by the liquids in his experiments, and that the bacteria alone remaining, it was very logical to attribute to them the infectious power possessed by the liquid of the last cultivation.

Paul Bert had at first believed, with Cohn, in the existence of a virulent agent other than the bacteria. Indeed, after having treated blood of charbon with compressed air and alcohol, which kill bacteria, he had been able to transmit charbon. But, abandoning this first idea, he expressed himself as of the same opinion as Pasteur and Joubert 
(July 30 of the same year), recognizing that the persistence of the virulence is due to spores (corpuscles germes) which resist all the causes of destruction.

Quite recently, finally, Toussaint, while studying the mechanism by which the bacteria cause the death of rabbits, horses, and sheep, arrives at the conclusion that it is because of asphyxia of mechanical origin, - enbolism of the pulmonary capillaries.

The phlogogène action of the vibrionien is sometimes such that, in addition to embolism, there is a rupture of the capillaries, and even lesions graver still.

"The phlogogène material is more active, according to the subjects from which the bacteria are obtained. The animals which I have studied may be arranged as follows: the rabbit, guinea-pig, sheep, ass, horse, dog." As to the hog, it is not at all susceptible.

In the last place, Toussaint has presented, through Bouley, a note upon a form of charbon caused by a Fibrion aérobie. This affection was already recognized as contagious, but the agent of conta= gion was not known. Toussaint has found that it is caused by a Bacterium, differing in certain characters from Bacillus; he has cultivated this microbe, and has seen it reproduce itself under the microscope, in an apparatus invented by Ranvier. The malady has been transmitted to rabbits in the same burrow without inoculation.

By taking the excrement, reduced to powder, of 
an infected animal, and sowing it upon the food given to an animal in good health, the latter has contracted the disease.

Malignant Pustule without Bacteria. - Besides the numerous facts concerning charbon, in which the presence of a bacterium has been verified, it is proper to cite those cases in which none has been discovered. Some authorities, such as Toussaint, Mannoury, and Salmon, who have given these instances, consider this absence of bacteria a favorable prognostic sign. The following wellmarked example has recently been observed :-

Louis Donin, a tanner, aged forty, was admitted to the Hotel-Dieu of Lyons, June 15th, 1876, service of Fochier. On the morning of June 13, he had noticed three large flies, eagerly attacking the skins upon which he was working. One of them bit him in the face. The same day his cheek swelled; during the night a large vesicle formed, surrounded by an areola of other smaller vesicles; the skin having become pruriginous, Donin rubbed the central vesicle. Upon his arrival bis general condition was satisfactory. Upon his left cheek was seen an areola of little vesicles surrounding a slough having a diameter of less than a centimeter. The periphery was oedematous and hard, trembling and extended downwards as far as the xiphoid appendix. The eyelids and the oedematous lips were opened with difficulty. In order to verify the diagnosis, Toussaint inoculated a rabbit with the debris of a pustule; a second, with blood; 
and a third, with serum. The result of these three inoculations was completely negative. The microscopic examination by Charpy and Colrat did not reveal the presence of any vibrionien. On the 16th of July, the patient left the hospital cured. Let us add that the interne of the service, having punctured his finger with a syringe employed in making injections of carbolic acid (twenty per cent), did not experience any ill effects.

Darreau, veterinarian at Courtalain, attributes to bad food this variety of charbon, in animals, without the presence of bacteria. He has described an epidemic on a farm where the forage was of bad quality. Charbon is then due, according to him, to impoverishment of the blood. Decroix, veterinarian in the army, has examined with the microscope the blood of horses submitted to his observation, from the jugular vein, and also the tumors. He has never found any bacteria. The horses have recovered. These experimental and clinical results have permitted Bouley to establish the unity of the charbonneuse malady, contrary to the opinion of Prof. Bouillaud, who renews the hypothesis of a multiplicity of charbonneuse affections.

In effect we see the same bacterium everywhere producing the same disorders. In the very rare and generally favorable cases of charbon which do not seem to be of bacterial origin, we may say with Pasteur, "When the parasite has not been perceived, it is probably because sufficiently high powers have not been used. The phlogogène ac- 
tion of the bacteria, brought to light by Toussaint, is necessary in order to explain the production of the tumors of charbon."

Davaine, in consideration of the immobility of the Bacillus anthracis, admits that every tumor results from a local inoculation. We have called attention to the fact that the virulent agents of variola and of rugeola, although motionless, produce nevertheless local manifestations. In the second place, the charbon of the horse is often accompanied by internal tumors of which the origin evidently cannot be an external cause. Finally we have pointed out by Bouley some horses of La Plata in which the local manifestations did not appear until after the general symptoms. This view had already been sustained by Chabert. However, notwithstanding all the proofs furnished turn about by experimental pathology and clinical study, one desideratum still remains. It is necessary to verify the presence of the spores of Bacillus anthracis in the lands where charbon prevails as an epizootic and to discover its means of transportation.

Before abandoning this question, we think it proper to examine the efficacy of antiseptic treatment. Carbolic acid, studied by Koch, has been employed with success; boracic acid, which acts upon the bacteria by depriving them of oxygen, has been utilized by Decroix, veterinarian of the army; tincture of iodine, employed, like carbolic acid, - by subcutaneous injections, - has given rise to grave accidents. Beside these general 
proceedings based upon the idea of an infection of the entire organism, are placed the local treatment destined to destroy the bacteria at their point of entry: these are, caustic potash, sublimate, the paste of Canqouin, the hot iron. These two categories of means employed sometimes alone, sometimes simultaneously, show that the idea of the clinicians has always been the destruction of an infectious organism.

Variola. - The partisans of the parasitic nature of variola may be divided into two groups: 1. Those who, with Coze and Feltz, attribute the virulence to a Bacterium; 2. Those who, with Luginbühl and Weigert, attribute it to a Micrococcus. Coze and Feltz have indeed discovered Bacteria in the blood of variola, and this blood injected into the veins of a rabbit has given it a mortal malady, which these observers consider variola. But Chauveau has shown that the affection which proved fatal to the subjects of the experiment was not and could not be variola. Another objection is that Bacteria are not found in all those who suffer from variola. However, Coze and Feltz and Baudouin affirm that there are in variolous blood numerous rods, of which the appearance is similar to that of Bacterium bacillus and Bacterium termo of Müller. These elements do not at all resemble those found in other infections, and when inoculated possess the power of reproducing variola.

As to the Micrococcus of variola, they have 


\section{PLATE $\mathbf{X}$.}

Copied from photographs by Koch in Cohn's "Beiträge zur Biologie der Pfanzen," Bd. II., Heft 3.

Fig. 1. - Bacilli of Miltzbrand from the substance of the spleen. $\times 700$.

Frg. 2. - Bacilli of Miltzbrand in blood of basilar artery collected two days after death. $\times 700$.

Frg. 3. - Spirillum Obermeieri. $\times 700$.

Fig. 4. - Bacilli of Miltzbrand cultivated in aqueous humor, showing development of spores. $\times 700.1$

1 The lithographer has not succeeded in making a satisfactory copy of Koch's photo-micrograph, in this figure. 


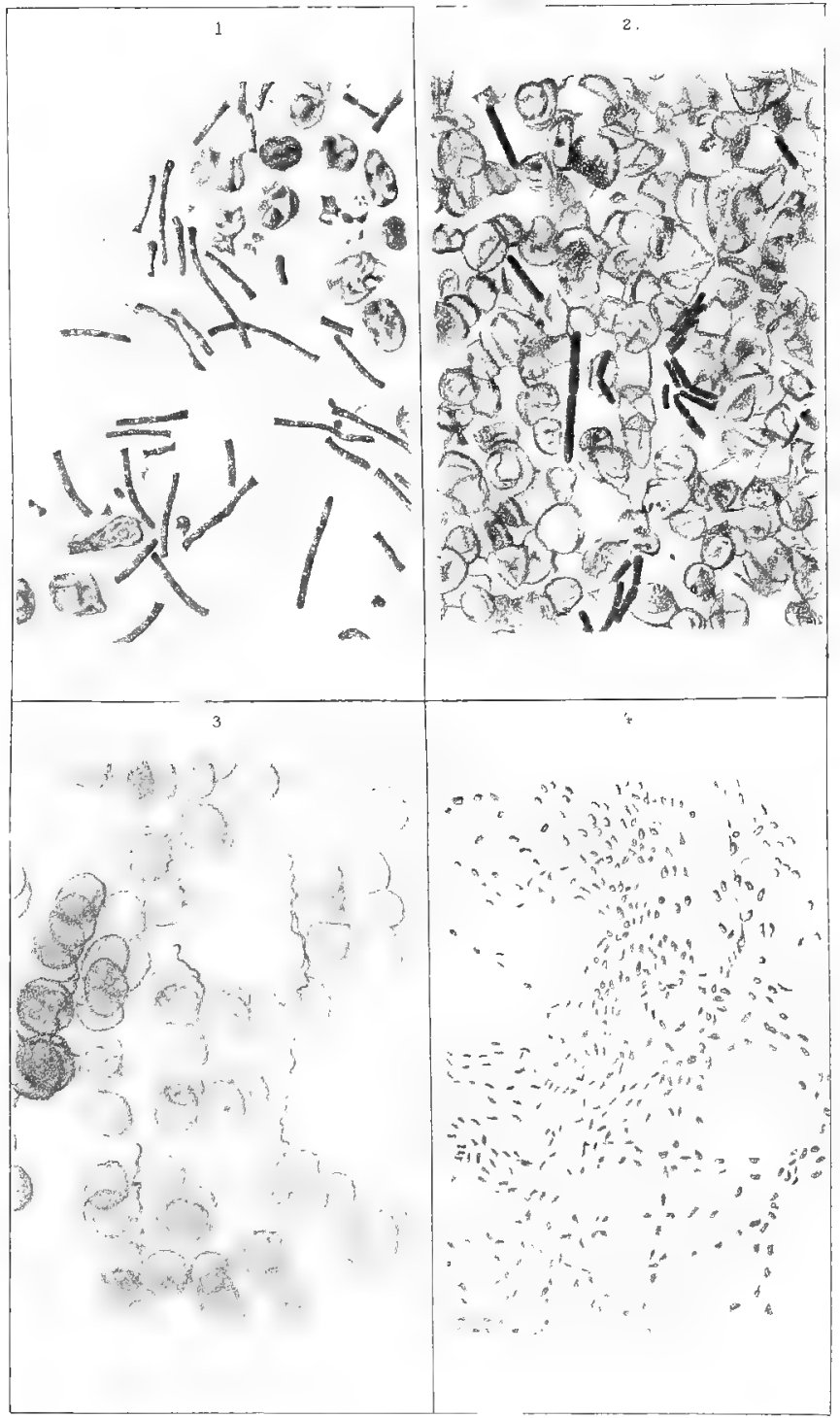



been studied by Luginbühl, Weigert, Hallier, and Cohn. These micro-organisms possess the characters of all the spherical bacteria, and are found in the variolous pustules, the rete Malphigii, the liver, the spleen, the kidneys, and the lymphatic ganglia. We can only insist upon the fact of the concomitance of the variola and the presence of Micrococcus, since experiment cannot be resorted to in this disease, of which the complete evolution only occurs in man. We also find in vaccine lymph analogous Micrococci, in every point of view, to those of variola. Cohn considers them both, not as distinct species, but as two races of the same species, - the Micrococcus vaccince.

Scarlatina. - Coze and Feltz have found in the blood of scarlet-fever, taken from patients, living or recently dead, some rods as well as mobile points. This blood injected into the cellular tissue of rabbits has sometimes produced death, and the blood of the animals experimented upon has presented the same bacteria as human blood of scarlatina: they are simply a little larger and longer. As to the mobile points, they appear to correspond to the Micrococcus of scarlatina described by Hallier.

Rugeola. - The examination of the blood of measles has shown to the same experimenters, bacteria of extreme minuteness and great mobility. The inoculation of this blood has not produced the death of rabbits; however, these animals have 
been sick for two or three days and have presented in their blood very slender and active rods. In the period of invasion the nasal mucus already contains small bacteriform elements.

Diphtheria. - All the labors undertaken since Tigri, by Trendelenburg, Ertel, Letzerich, Tommasi, and Hueter, from a parasitic point of view, have attributed diphtheria to the presence of a Micrococcus. There is however a single exception, Eberth of Zurich, in a work published in 1872, regards a Bacterium as the agent of the diphtheritic contagion.

According to new researches, which appeared in 1873 , the pus of pyæmia, or of purulent peritonitis, inoculated, produces diphtheria because of the presence in it of bacteria.

Laboulbène had already pointed out the presence of Bacterium, accompanied by Vibrios and $\mathbf{M i}$ crococcus in pseudo-membranous affections. Some researches made in collaboration with Robin had given the same result, but these savants did not admit a relation of cause to effect between the micro-organisms observed and diphtheria. According to Duchamp, as shown by experiments cited in his inaugural thesis (1875), there are in false membranes Bacteria, Vibrios, and granulations.

Taken alone, these micro-organisms appear to possess a very injurious action, but their inoculation does not produce diphtheria. The demonstration of a causal relation between the Micrococcus 
and diphtheria is not, then, yet established by these last experiments.

Typhoid Fever. - Tigri first found bacteria in the blood of a man dead with typhoid fever. These organisms were also found by Signol (1863) and Mégnin (1866) in the blood of horses attacked by a disease called by the veterinarians typhoid fever. This blood, by inoculation, produced the death of some rabbits, with the same alterations in the blood.

Coze and Feltz (1866), having inoculated some rabbits with the blood of typhoid fever, have produced results which they consider analogous and as accompanied by the same pathological localizations in the glands of Peyer. The blood of an injected rabbit may be used upon a second rabbit, with positive results, as in variola and scarlatina.

The species of Bacterium which is found in this case recalls the Bacterium catenula, but its dimensions are less.

Glanders and Farcy. - The universal recognition of the contagious power of a liquid coming from an animal with glanders had, $\alpha$ priori, led to the supposition of an element of special contagion. The first indication was given by Christot and Kiener (1868). These experimenters discovered in the secretions and vascular glands of animals attacked with glanders, bacteria of two sorts: 1. Rods, sometimes having a vibratory motion without changing place, sometimes having 
a rectilinear or eccentric motion of translation;

2. Some spherical granules of variable diameter, homogeneous, animated by a rapid gyratory movement and a movement of translation in various directions. The latter are certainly Micrococci. Chauveau, in an experiment designed to demonstrate that the organisms alone are active, took ten grammes of pus from a pulmonary abscess of a horse attacked with acute glanders: the virulent elements were so numerous that the water became opalescent. This pus was washed four or five times in five hundred grammes of distilled water, was then collected and dried, and finally was inoculated, and the inoculated animal perished with glanders. Another, on the contrary, into which the filtered liquid was injected presented nothing abnormal. The particulate elements are, then, alone active. But in glanders, as in charbon, contagion is not always demonstrated. There are cases in which spontaneous origin appears incontestable (case of M. Boulay d'Avesnes, three cases cited in the "Recueil de Médecine Vétérinaire," June 15, 1877).

Finally, this opinion has recently been supported by Delamotte, who accords in this with Tabourin, Bonnaud, and Chénier. We might perhaps see in these cases the action of a minute germ, playing, in regard to the bacterium of glanders, the same rôle as the germ of charbon does with regard to the Bacillus anthracis. This is an hypothesis which no researches have yet confirmed. As proof of the functional analogy which may 
exist between the bacteria of 'glanders and of charbon, we recall the fact that Bédoin, having mixed some powdered borax (two grammes) with the blood of a glandered horse, has found the bacteria completely motionless at the end of two hours. These results correspond with those which Decroix, veterinarian of the army, has obtained by treating horses attacked with charbon with boracic acid.

Ulcerative Endocarditis. - In this affection, it is well settled to-day that the cardiac walls and, above all, the valves are covered with parasitic masses. Some think that the malady is due to the introduction of these parasites into the interior of the tissues; others, on the contrary, like Hiller, deny that the bacteria bear any causal relation with the lesions of ulcerative endocarditis. Gerber and Birsch-Hirschfeld have recently made an observation which is a complete refutation of the ideas supported by Hiller. They have found at the autopsy some hemorrhagic foci disseminated in various organs, the greater number of which contained some particular corpuscles belonging to the class of the bacteria.

Relapsing Fever. - In 1868, Otto Obermeier discovered in the blood of the sick attacked with recurrent fever certain bacteria, called by Cohn Spirochote Obermeieri. These organisms are only found during the febrile paroxysm; after the access of fever they disappear, but often they are 
agrain found a few hours before the new access. They are no longer found when convalescence is established. Heidenreich, Weigert, Birsch-Hirschfeld, and Cohn have confirmed these observations.

\section{Intermittent Fever. - In all the analyses of air} made in the vicinity of lands where this fever prevails, numerous inferior organisms have been found. I refer to a previous work for additional information, ${ }^{1}$ and limit myself to pointing out the observations of Griffini, who has found in the dew of places subject to this fever, Vibrio bacillus, $V$. lineola, Bacterium termo, $B$. catenula, etc. ${ }^{2}$

1 Ant. Magnin, Rech. Geol., Bot. et Stat. sur l'Impaludisme dans les Dombes, et le Miasme Paludéen. Paris, 1876.

2 "Professors Klebs and Tommassi-Crudelli, who have recently spent some time in the neighborhood of Rome with the intention of investigating the cause of malarial fevers, have published an account of their researches. Fron an abstract of their report, published in a recent number of the 'Medical Times and Gazette, we learn that the investigators followed a very deliberate plan in the performance of their task. ...

"Professors Klebs and Tommassi-Crudelli first succeeded in producing the symptoms of malarial poisoning in animals by injection of watery extracts from the marshy soil. They then proceeded, by the process called 'fractional cultivation,' to isolate the active material, that is, the true generator of the disease, supposed to be a living organism. Lastly, they isolated the organisms by filtration; and, comparing the results obtained in injections of the filtrate with those produced by the residue containing the organisms, they proved that the poison of malaria resides in these. 'The fungi obtained appeared as small rods of 0.002 to 0.007 millimeter in length, growing into long, twisted threads. The fungus is markedly aerobiotic. If air is excluded, it dies out. The injection of these fungi - true bacilli malaria - into healthy animals always gives rise to symptoms of intermittent fever, with enlargement of the spleen, etc. Later, Dr. Marchiafava, at Rome, was able to demonstrate spores and bacilli in the spleen, the marrow, and the blood of three persons who had died of pernicious fever, showing the same characters as those observed by Klebs and Crudelli. In summarizing the results of their investigations, the authors consider the following facts as proved: 1. That 
THE BACTERIA IN SURGICAL LESIONS.

§ 4.- OF THE Rôle OF THE Bacterta IN Surgical Lesions.

Existence of Bacteria in the Liquids secreted by Surgical Lesions. - Since the day when therapeutics has entered upon a road truly scientific, the study of the liquids secreted upon the surface of divided tissues has occupied an important place in the observations and researches of surgeons. Little by little the discussion of operative methods has fallen to the second place, so that to-day, both in the press and in the societies, but little attention is given to the mode of proceeding or to the form of the flaps; but the greatest interest is taken in all questions touching the pathological physiology of solutions of continuity. Thirty years ago it was to chemistry that we looked for an explanation of the complex phenomena which favor or prevent the cicatrization of wounds: to-day it is above all to the microscope; or rather it is to that part of chemistry which is the most particularly indebted to the microscope for the progress which it has accomplished, that is to say, to the science of ferments, to zymotic chemistry. To show by what labors this tendency has been brought about, to what facts they have led, and what progress has been realized, is the object which we propose to ourselves in this paragraph.

it is possible to reproduce malarial infection in every form in rabbits in which it is known in men; 2. That the malaria produced artificially in animals is generated by organisms existing in the malarial soil at a time when the outbreak of the fever has not yet taken place." - Extract from Leading Article in "Philadelphia Medical Times," March 13, 1880. 
Bacteria in Liquids Exposed to the Air. - In order to comprehend the importance of bacteria from a surgical point of view, it is sufficient to put a drop of pus from an open wound under the microscope. In the majority of cases the presence of bacteria will be demonstrated. And, truly, there is nothing in this which should astonish us, if we remember what has been said above, since we know the facility with which these vegetables develop in all the liquids of the organism, and the resistance which they offer to all but the most powerful agents. However, all pus is not equally suitable for the development of these organisms. It is easy to remark that they are more abundant in pus of a bad character, in that which smells bad and exhales an odor of butyric acid. They are also more commonly found in pus which has remained a long time in wounds having hidden sinuses. But while recognizing these differences, we must confess that there is nothing absolutely fixed about them, and above all that they do not bear a constant relation with the conditions which govern the genesis of putridity.

It is certain, also, that the conditions surrounding the sick person, the quality of the air in which his wound is bathed, are conditions which it is necessary to consider. And this results from what we have said relative to atmospheric germs. For example, when we submit to maceration in distilled water, dust gathered in a hospital, on one hand, and on the other, dust from a different locality, taken in the country, for instance. The 
first will much sooner develop Micrococcus, etc., and in far greater numbers (L. Julien). Now it is evident that this result is exactly applicable to the subject which occupies us, since the pus of wounds exposed to the air can be compared, in a certain measure, to the infusions of dust.

As to the elements found in pus, they are equally variable. Most frequently the cocco-bacteria present themselves in the form of little chains (strepto-bacteria). They rarely exhibit any movement. The appearance of bacteria upon the surface of wounds occurs at the end of sixteen to twenty-four hours. During the first hours following the division of the tissues, as is well known, the only exudation which appears is a yellowishpink serum. In this inflammatory exudation, which always contains a considerable quantity of blood globules, the parasites do not at once appear. But, as I have said, at the end of a day or two Micrococci and Bacteria in chains, very small, and of average size, make their appearance. It seems, then, as has been remarked by G. Nepveu, to whom we owe an excellent work on "The Rôle of Inferior Organisms in Surgical Lesions," that this first secretion of wounds is quite propitious for the development of bacteria; and, perhaps, we might be able to draw from this fact an argument in favor of their formation and their existence in the blood. Later, with free suppuration, the inferior organisms increase still more. It is, however, to be remarked that they are never very abundant upon the surface of healthy wounds. If we gather this 
pus, and preserve it in the open air for some time, we may follow the increasing development of these germs. An important remark, due to Dr. Mollière of Lyons, is that the phenomena of putrefaction are hastened by the presence of blood in the purulent liquid. A quantity of pus drawn by aspiration from a deep abscess, and not mixed with blood, was exposed to the air for fifteen days, without any bad odor being developed.

Bacteria in Purulent Collections not Exposed to the Air. - In 1875, Dr. Albert Bergeron communicated to the Academy of Sciences (Séance of Feb. 26) the results of numerous observations made in the service of Prof. Gosselin, for the purpose of ascertaining if the pus of abscesses contains bacteria. The following are the conclusions of his memoir:-

1. Vibrios are found in the pus of abscesses, without any contact with the external air and without, usually, any indication that the organism is seriously infected by their presence; 2 . We cannot admit that in these cases the vibrios have penetrated into the interior of the abscess through the lymphatic system, or through the circulatory system, both being intact. The pus of warm abscesses in adults often contains vibrios; if they occur in the case of infants the fact has not been observed; 3. The pus of cold abscesses in the adult, as in the infant, never contains them; 4. The vibrios may be considered as indicating a serious inflammatory state, and a certain tendency to decomposition of 
the humors which contain them, without, however, as a rule, exercising any toxic action upon the organism; 5. The author is far from rejecting the possible intervention of vibrios in the pathology of purulent infection; and he explains the happy exemption of infants from septicemia, in a majority of cases, by the fact that these organisms are not found in the pus of abscesses in young children.

The conclusions of the memoir of $\mathbf{M}$. Bergeron were the object of earnest discussions. According to the accepted theory, there ought never to be a development of organisms, unless the germs had been introduced from the air; if, then, we admit the correctness of these observations, the explanation given by Pasteur breaks down. Let us add, that many times, by the bedside of the patient, the microscope has furnished results absolutely contradictory. Sometime before M. Bouloumié had formally established, as the result of long continued researches, that pus coming from any collection whatever, not in communication, directly or indirectly, with an open wound, never contained organized elements, mobile or motionless, which can be considered as microzoa, or microphytes, except some highly-refractive moving points, often joined together in pairs.

We dare not say that the long discussions to which these communications have given rise have thrown any light upon the grave problems which they have attempted to resolve. Let it suffice for us to have pointed out these different points of view. 
Of the Effects of Bacteria. - It would be rash to attempt to-day to give a definite verdict upon the greater or less noxiousness of the bacteria. At the outset of the studies which disclosed their presence in many pathological liquids, it was believed that we had finally found the true explanation of the obscure phenomena which retard or complicate the normal repair of wounds. But what shall we think to-day of the redoubtable rôle which was at first attributed to a microbe, when we ascertain that its development is not fettered by the clinical means which are most highly praised? These are the difficulties of the problem upon which the future will, without doubt, shed some light, but of which - I repeat it - notwithstanding the amount of labor which they call forth every day, it is not possible for us to formulate the solution to-day. Let us try, however, to indicate that which experiment has taught us up to the present time.

Upon the surface of a granulating wound, not offering to absorption any vascular or lymphatic orifice, it is to be believed that the microbe constitutes only a very contingent danger. It may multiply in greater or less degree, and will absorb more or less oxygen, giving birth, perhaps, as a result of chemical decompositions, to a virus upon the surface of the wound, which, notwithstanding, will arrive at cicatrization. But, if a solution of continuity happens to break through the thick layer of fleshy granulations, either by the spontaneous movements of the patient or by those 
which occur in dressing the wound (the pressure and manipulations which it was formerly customary to resort to), a rent being produced, the infectious agent will be able to penetrate into the blood current or into the lymphatics, and the door will thus be opened to local or general complications.

As a local complication, we should cite, above all, l'abcès de voisinage. If the presence of bacteria in the pus of spontaneous abscesses is still under discussion, all observers are agreed as to their presence in secondary purulent collections. Bouloumié has taught us that in pus coming from abscesses developed in the parts in the vicinity of a wound, whatever may be its extent and depth, we may verify the presence of all the microorganisms found in the pus of the wound, or certain ones only, according as the abscess is developed in parts continuous with or contiguous to the tissues of the wound. There is then no doubt that, in this case, these elements are absorbed, or at least find their way through the veins or lymphatics. The inflammatory action of micro-organisms, thrown thus into the midst of healthy tissues, even of those which become inflamed with the most difficulty, is easy to demonstrate.

The following unpublished experiments upon this point have been communicated to us by our friend Dr. Louis Jullien :-

Experiment 1. - Having gathered some dust in the surgical wards at Lyons, I put it in a flask of distilled water. At the end of some days I had thus given rise 
to the development of numerous micro-organisms, the most common form being Bacterium.

The 20th of May, 1873, with a Pravaz syringe, I injected four drops of this liquid into the right ocular globe of a rabbit. Immediately afterward, the iris bulged forward, became clouded, and the pupil dilated irregularly. As a result of this injection a terrible inflammation was developed. On the 25th I note an intense conjunctivitis and a roughness of the cornea, from which the epithelium has disappeared at certain points. Upon the posterior surface of the cornea is a white cloud occupying the inferior part of the pupillary opening, more opaque in certain points and presenting the appearance of a hypopyon; the iris was still bulged forward, tomentous, of a violet red color; pupil contracted.

June 4, the iris is still bulged forward, so as nearly to touch the cornea; the crystalline lens is also pushed forward.

June 5. By aspiration I withdrew from the vitreous a sort of membrane having the form of a whitish filament. Upon examining this with the microseope, I recognized the presence of pus globules, cryptococcus, and bacteria.

June 10. The ocular inflammation has disappeared, but a cataract remains.

ExP. II. - The same as the preceding. When the syringe was withdrawn from the vitreous, into which four drops were injected, a chemosis occurred, resulting no doubt from the fact that a little fluid was extravasated into the sub-conjunctival tissue. Operation made May 25.

29. Intense ocular inflammation, conjunctiva of a uniform red color ; cornea clouded, of a pearl gray tint; iris very red, tumefied. The animal seems to suffer much when it is examined. 
30. Still much inflammation, the ear is very warm, fever intense.

June 4. A capsular cataract is recognized, white, milky, and glistening.

5. Aspiration by means of Pravaz syringe. A white membrane was obtained and examined under the microscope. It contained a great number of pus corpuscles, a very great quantity of highly refractive yellowish bodies, resembling cryptococcus, and a small number of bacteria.

10. The inflammation is still considerable.

ExP. III. - As a control experiment I made an injection of distilled water into the eye of a rabbit. The injection was well made, and, as in the preceding case, a chemosis occurred.

June 10. There has been no reaction of any sort, either local or general, and it is impossible to distinguish the eye into which the injection was made.

The inflammatory properties of the micro-organisms being demonstrated, we can easily understand the pathology of an abcès de voisinage, and we conceive also the consecutive formation of new abcesses as a result of the first. This is one of the modes derived from a local process by which purulent infection is accomplished.

As a general complication, we must mention the penetration of the microbe into the blood, and the possibility, thanks to this liquid, of the infectious agent being transported to all the organs, where it will form, either centres of softening and suppuration, which have been called metastatic abcesses, 
or, by a little different mechanism, veritable embolisms.

A very curious fact was published not long since, which supports this view. This observation is due to Hjalmar Helberg (of Christiania). In the case of a woman in whom the mucus membrane of the uterus was found to be covered with a great number of micro-germs, the tissues of the eye presented a series of lesions, which microscopic examination showed to be due to the presence of parasites. In the cells of the cornea, in the vessels of the choroid and of the retina, were seen veritable plugs containing bacteria identical with the micro-organisms found in the genital parts. The author admits that the ocular inflammation had been produced by septic embolisms.

I will not insist further upon the embolic process, which is studied in another chapter of this work.

To sum up, I will say that, so far as the influence of bacteria on wounds themselves is concerned, we know as yet nothing positive; since, as I have said, we find these parasites upon the surface of solutions of continuity which progress most rapidly and surely to a cure. Better informed in regard to the generalization of the process and the infection of the organism by products formed on the surface of the wound, we cannot dissimulate the fact that much of our information is still upon the borderline of hypothesis, and that it would be imprudent to accept it yet as invariably settled. According to all probability, we will find the key to these 
obscurities when we know better how to distinguish the different kinds of microphytes. Indeed, while Billroth only admits two invariable fundamental types, Coccos and Bacteria, Weigert has recently expressed views quite opposed to these in speaking of the bacteria of fermentations and of chromogenes, which according to Cohn and Pasteur constitute as many physiological species as there are different fermentations and colorations. According to Weigert, there are an infinite number of sorts of bacteria, arising from the fact that each Micrococcus assumes special vital properties according to the medium in which it finds itself, and consequently gives birth, as the result of decompositions which it effects in taking possession of oxygen, to various chemical products acting as morbid viruses.

Influence of the Preceding Notions upon Therapeutics. - We have just shown that for many authors germs are the origin of the greater part of the complications of wounds, it was then natural that they should seek to prevent their development. In order to attain this result, the clinicians have used means either physical or chemical.

M. Alphonse Guérin, founding his practice upon the ideas of Pasteur regarding the possibility of filtering and purifying the air by passing it through cotton-wadding, conceived the idea of covering wounds with a considerable quantity of cotton, and realized - the fact cannot be denied-an immense progress in the treatment of sexere traumatisms. 
But while the surgeon attributed his success to the absence of germs, and gave all the credit to M. Pasteur, the microscopists had no difficulty in proving that, far from being exempt from them, the pus of the wounds kept under these dressings swarmed with micro-organisms. It was, then, to some very different conditions that the real progress as realized by M. Guérin should be ascribed. The constant temperature, the absolute immobility, the continued pressure, and consequent absence of any rent of the tissues, as well as the absolute want of absorbent openings upon the surface of the wound, are probably the circumstances to which so many happy cures have been due since 1870 .

Among the chemical agents to which recourse is had we must place in the front rank carbolic acid, extolled especially by Lister. Not more than for M. Guérin can we deny the fact that the number of cures after severe surgical operations has been considerably increased by operating under a cloud of pulverized carbolic acid solution, and applying upon the wound nothing but dressings which have been for a long time submitted to the action of this agent. But in this instance also the interpretation was a mistaken one, in seeking the secret of success in the exclusion of every microbe; for, in a great majority of cases, Virchow has not been able to find any appreciable difference between the pus treated by the old methods and that of wounds submitted to that of Lister. And, nevertheless, purulent infection disappeared, complications of all kinds diminished singularly in fre- 
quency; and union by first intention is attempted and often obtained in very extensive wounds, where formerly it could not have been hoped for, even in the cases which presented the most favorable appearance.

Let us rejoice that we can record such favorable results; and, however cloudy the present theories concerning bacteria may be, let us recognize that the labors of Pasteur and Cohn have at least had the merit of inspiring great reforms, which are subjects of just pride in the operative surgery of the present day.

Many other substances have also been praised as being an obstacle to the development of germs. We will only mention the permanganate of potash, the hyposulphites, chlorine water, and tincture of eucalyptus, of which the action is doubtful. We must still mention glycerine, which from its affinity for water has the property of fettering the movements of bacteria, and determining at their expense a considerable exosmosis.

We will not return here to the subject of the origin of micro-organisms, but refer the reader to the chapter in which this has already been treated. 


\section{CONCLUSIONS.}

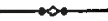

WE may sum up as follows the actual state of our knowledge upon the bacteria:-

1. The bacteria are cellular organisms of vegetable nature.

2. Their organism is more complicated than was for a long time believed. The principal points brought to light are: their structure, the presence of cilia, the nature of the substances contained in their protoplasm, - colored granules, grains of sulphur, etc.

3. The forms of torula, zoogloe, leptothrix, mycoderma, etc.

4. The multiple affinities of the bacteria, on the one hand with the algre, on the other with the fungi, differently understood by authors, and their development, still unknown for the greater number of species, make it impossible to classify these beings except in a provisional manner.

5. This development, well studied in several species of Bacillus, has proved that bacteria may multiply not only by fission, but also by formation of spores, and even by veritable sporangia.

6 . These spores or permanent germs are the 
principal means by which these inferior organisms are disseminated.

7. As to their rôle in fermentations, in putrefactions, in contagious diseases, and in surgical lesions, notwithstanding the considerable number of labors of which the bacteria have been the object in these different points of view, it is not yet possible to define it in a certain manner. ${ }^{1}$

I The candid statement made in the last paragraph by a savant who has shown himself so familiar with the whole subject, and by a Frenchman who evidently has a high regard for his distinguished countryman, Pasteur, shows us that there is still much to be done in the way of careful and conscientious work in the study of the life-histories and physiological functions of the micro-organisms known under the general name of bacteria. - G. M. S. 



\section{B I B LI O GR A P H Y.}

1722. Leedwenhoek. - Op. omnia, t. I; Anat. et Contemp., p. 37, Lugd. Batav.

1773. Mulder, O. F.- Vermium terrestrium et fluviatilium historia.

1786. Muller, O. F. - Animalia infusoria flur. et marina.

1793. Lavorsier. - Traité élémentaire de Chimie, t. II.

SCheELE. - Sämmtliche Werke, t. II. p. 249.

1799. Fabroni. - Mém. sur les ferment. vineuse, putride, acéteuse. In Ann. de Chimie, t. XXXI.

Spallanzant. - Opuscules de physique animale et végétale, traduits par Senebier, 1877.

1800. Proust. - Expérience sur l'urine, in Ann. de Ch. et Phys., t. XXVI.

Provst. - Faits pour la connaissance des urines et des calcules. Ann. de Chim. et Phys., $2^{\mathrm{e}}$ série, t. XIV.

1803. Berthollet. - Statistique chimique, t. II.

1804. De $\mathrm{S}_{\mathrm{A} \text { ussure. }}$ - Recherches sur la végétation, p. 143.

1810. Gay-Lussac. - Mémoire sur la ferment., in Ann. de Chim., t. LXXVI.

1815-23. Barthíd. EMY. - Comptes-rendus des travaux de l'École d'Alfort.

1822. Gaspard. - Mémoire phys. sur les maladies purulentes et putrides. In Journ. de Magendie.

1823. Dobereiner. - Journ. de Schweigger, t. VIII.

1824. Bort de Saint-Vincent. - Encyclopédie méthodique. 1825. Col in. - Mém. sur la fermentation vineuse. In Ann. de Chim. et Phys., 2e série, t. XXVIII.

Degmazik̀res. - Sub mycoderma cerivisiæe et malti-juniperini (Ano. des Sc. nat. $1^{\mathrm{ro}}$ série, t. $\mathbf{X}$.). 
1828. Dumas et Bouliat, Ann. de Chim. et Phys., t. XXXVII. Turpin. - Mém. sur la fermentation alcoolique et acéteuse. Mém. de l'Ac. des Sc.

1829. Berzelius. - Traité de Chimie, t. VI.

1830. Bory de Saint-Vincent. - Dict. classique d'hist. nat. 1836. Cagniard de Latour. - Ann. de Chim. et de Phys. $2^{e}$ série, t. LXXVIII. Mémoires de l'Institut, 23 novembre.

Donnt. - Animalcules observés sur les matières purulentes et le produit des sécrétions des organes gënitaux de l'homme et de la femme. C. R. Ac. de Sc., t. III, p. 385 .

1837. Donne. - Recherches sur la nature des mucus et des divers écoulements produits par les organes génitourinaires de l'homme et de la femme. C. R. Ac. des Sc., t. IV, p. 464.

Schwann. - Ann. Poggendorf, t. XLI.

1838. Ehrenberg. - Infusoriens Thiere.

Kutzing. - Répertoire de Chimie.

1841. Dujardrn. - Hist. nat. des Zoophytes infusoires. Paris.

1842. Dárat. - Abcès multiple et présence du pus dans le système vasc. Th. de Paris.

1843. Andral and Gavarret. - Recherches sur le mode et les circonstances de développement d'un végétal microscopique dans les liquides albumineux, normaux et pathologiques. Gaz. méd. de Par. XI. p. 87-91.

Dumas. - Traité de Chimie appliquée aux arts, t. VI.

1844. Gonther. - Développement des abscès dans le poumon des chevaux: In Mag. f. die Gesammte Heilk.

Pelodze et Gelis. - Ferment. butyrique. In Ann. de Chim. et Phys.; t. X, p. 434.

Pelodze et Gelis. - Ferment. lactique. In Ann. de Ch. et Phys. t. X.

1845. LÉBRrT. - Phys. pathologique.

1846. Castelnan et Ducrest. - Cas où l'on observe des abcès multiples. In Mém. Ac. de Méd.

1847: Се. Roвin. - Des fermentations. Thèse d'aggrégation. Dobrdnfadt. - Sur une propriété analyt. des ferment. alcoolique et lactique. In Ann. de Ch. et Phys., $3^{e}$ série, t. XXI. 
1849. Pouchet. - Infusoires microscopiques dans les déjections alvines de cholériques. C. R. Ac. des Sc., 23 avril.

Sedillot. - De l'infection purulente ou pyohémie. Paris.

1852. Perty. - Zur Kentniss kleinster Lebensform. Berne. Thomson. - Ann. der Chem. und Pharm. t. LXXXIII. 1853. СoнN. - Ueber die Entwicklung. mikroscop. Algen u. Pilze Nova acta Acad. nat. cur. XXIV.

1854. Hassald, A. H. - On the Development and Signification of Vibrio ureola, Bodo urinaris, and on certain Fungoid and other Products generated in Alkaline and Albuminous Urine. Lancet. Lond. II. p. 10.

1855. Gangee. - Exp. sur l'inject. du pus dans les vaisseaux sanguins. In Gaz. méd. de Lyon.

A. Hill Hassall. - Report on the Examination of certain Atmospheres during the Epidemic of Cholera, by Dr. Thomson. In the Relation of Cholera Epidemic of 1854 , p. 119.

A. Hild Hassall. - Report on the Microscopical Examination of the Blood and Excretions of Cholera Patients. In Relation of Epidemic Cholera of 1854.

1855. Pollender. - Etude microscopique et microchimique du sang de rate. In Vierteljahrschr. f. gerichtl. medizin, t. XIII, p. 103.

Rainex. - In General Board of Health; Appendix to Rep. of the Com. for Scient. Inquiry in Relation to the Cholera Epidemic of 1854.

1856. PANUM. - Biblioth. f. læger ou Schmitt's Jahrbucher.

1857. Bradelc. - Sur le sang de rate. In Virchows Archiv., t. XI, p. 132, et t. XIV, p. 432.

Pastedr. - Mém. sur la fermentation appelée lactique. C. R. Ac. des Sc., t. XLV.

1858. Pasteur. - Mém. sur la fermentation de l'acide tartarique. C. R. de l'Ac. des Sc. t. XLVI, p. 615.

Pouchet et Houzead. - Proto-organismes végét. et anim. nés spontanément dans l'air artific. C. R. Ac. des Sc, t. XLVII, p. 982.

1859. C. Davaine. - Traité des entozoaires. Paris. 
1859. Pasteur. - Nouveaux faits pour servir à l'histoire de la levûre lactique. C. R. Ac. des Sc., t. XLVIII, p. 337.

Podchet. - Hétérogénie ou générat. spont. Paris.

Povchet, - C. R. Ac. des Sc., t. XLVII, XLVIII, L'; LI.

1860. JaCQuemart. - Ann. de chim. et de phys. $3^{e}$ série, t. VII.

JoLy et Musset. - Exp. sur l'hétérogénie. C. R. Ac. des Sc., t. LI, p. 627.

Horfmann. - Etudes mycologiques sur la fermentation. Ann. des Sc. nat. bot., t. XIII.

Moller. - Journal f. Prakt.-Chemie, t. LXXXI.

Pasteor. - Expérienoes relatives aux générat. dites spontanées. C. R. Ac. des Sc., t. L.

Pasteur. - De l'origine des ferments. C. R. Ac. des Sc., t. L.

Pasteur. - Recherches sur le mode de nutrition des Mucédinées. C. R. Ac. des Sc., t. LI.

Pasteur. - Nouvelles expériences relatives aux générat. dites spontanées. C. R. Ac. des Sc., t. LI.

Pasteur. - Note rélative au Penicillium Glaucum. C. R. Ac. des Sc. t. LI.

De Quatrefages. - Nouv. rech. frites en 1859 sur les maladies actuelles du ver à soie. Paris. (Masson.)

Saint-Prerre. - De la fermentation et de la putréfaction. Thèse d'agrégation de Montpellier.

1829-61. Ehrenberg. - Abhand. Akad. der Wissensch. zu Berlin.

1861. Pastedr. - Expériences et vues nouvelles sur la nature des fermentations. C. R. Ac. des Sc., t. LII.

Pasteur. - Animalcules infusoires vivant sans oxygène libre et déterminant des fermentations. C. R. Ac. des Sc. t. LII.

1862. Monorer. - Thèse d'agrégation. Des fermentations. Strasbourg.

Pastedr. - Examen de la doctrine des générations spontanées. Ann. de. Chim. et Phys., $3^{e}$ série, t. LXIV.

Pastedr. - Discussion relative à la générat. spontanée. C. R. Ac. des Sc. 
1862. Pasteur. - Mém. sur les corpuscles organisés qui existent en suspension dans l'atmosphère. C. R. Ac. des Sc. t. LII, et Ann. de Chim. et Phys., $3^{\text {e }}$ série t. LIV.

1863. C. Davaine. - Recherches sur les maladies charbonneuses. C. R. Ac. des Sc. t. LVII, p. 220, 351, 386, et t. LIX, p. 393.

Flodrens. - Note sur l'infection purulente. C. R. Ac. des Sc.

LeMaIRE. - Recherches sur les microphytes, les microzoaires et les fermentations. C. R. Ac. des Sc., to LVII, p. 625, t. LIX, p. 317-425.

Pasteur. - Examen du rôle attribué an gaz oxygène atmosphérique dans la destruction des matières animales et végétales aprés la mort. C. R. Ac. des Sc., t. LVI, p. 734 .

Pasteur. - Recherches sur la putréfaction. C. R. Ac. des Sc., t. LVI.

Signol. - Présence des bactéries dans le sang. C. R. Ac. des Sc., t. LVII, 348.

Tigri. - Șur la présence d'infusoires du genre Bacterium dans le sang humain. C. R. Ac. des Sc., t. LVII. p. 633.

Tigri. - Note sur un nouveau cas de Bactérie dans le sang d'un homme mort de fièvre typhoïde. C. R. Ac. des Sc., t. LVII, p. 833.

1864. C. Davaine. - Recherches sur les Vibrioniens. C. R. Ac. des Sc., t. LIX.

Davaine et Ratmbert. - Sur la présence des Bactéridies dans la pustule maligne chez l'homme. C. $R$. Ac. des Sc., t. LIX.

LePLat et JaIllaRd. - De l'action des Bactéries sur l'économie animale. C. R. Ac. des Sc., t. LIX, p. 250.

Pastedr. - Mém. sur la ferment. acétique. Ann. scient. de l'Ecole normale, t. I.

Potchet. - Production des Bactéries et des Vibrions dans les phlegmasies des bronches, des fosses nasales, et du conduit auditif externe. C. R. Ac. des Sc., t. LIX, p. 748.

TIGRr. - Considérations sur les infusoires du genre Bac- 
terium presentées à l'occasion des observ. de MM. Leplat et Jaillard. C. R. Ac. des Sc., t. LIX, p. 525. 1864. Van Tibghem. - Recherches sur la fermentation de l'urée et de l'acide hippurique. Ann. scient. de l'Ecole normale, I. et C. R. Ac. des Sc., t. LVIII.

De Vaurfal. - Essai sur l'histoire des ferments. Paris.

Oтto Weber. - Etude expérimentale sur la pyémie, la septicémie et la fièvre. In Deutsche Klinik.

1865. Birlroth. - Observations sur les fièvres traumatiques et les compilations accidentelles des blessures. In Archiv. f. Chirurg.

Davaine. - Rech. sur la nature et la const. anat. de la pustule maligne. C. R. Ac. des Sc., t. LX, p. 1296.

Leplat et JaILlart. - Note sur la non-existence des Bactéries chez les lapins morts à la suite d'inoculation du charbon avec les phén. du sang de rate. C. $R$. Ac. des Sc., t. LXI. p. 298.

Leplat et JaILlart. - Nouvelles exp. pour démontrer que les Bactéries ne sont pas la cause du sang de rate. C. R. Ac. des Sc., t. LXI, p. 436.

RABENHORST. - Flora europoea Algarum aquæ dulcis et submarinæ. Leipsig.

1866. Béchamp. - Réponse aux observ. de M. Pasteur, etc. C. R., p. 426 .

A. Chavannes (de Lausanne). - Les principales maladies des vers à soie. Genève, Cherbulier, $18 \mathrm{~b} 6$.

Coze et Fextz. — Recherch. expér. sur la présence des infus. dans les maladies infect. Paris et Strasbourg.

Davaine. - Sur la présence constante des Bactéridies dans les animaux infectés de maladies charbonneuses. C. R. des Ac. Sc., t. LXI, p. 334.

Davanne. - Recherche sur une maladie sceptique de la vache, regardée comme de nature charbonneuse. C. R. Ac. des Sc. t. LXI, p. 368.

Dovnt. - Sur la génération spontanée des animalcules infusoires. C. R. Ac. des Sc., t. LXIII, p. 1072.

Donkk. - De la génération spontanée des moisissures végétales et des animalcules infusoires. C. R. Ac. des Sc., t. LXIII, p. 301. 
1866. Guérin-Méneville. - Note sur la maladie des vers à soie. C. R. 3 Sept. 1866.

HrmmeR. - Etude sur l'effet des matières putrescentes sur l'organisme animal. Munich.

JoLY. - Examen critique du mém. de M. Pasteur ayant pour titre "Nouv. Etudes sur la maladie des vers à soie" (Ext. du Journ. d'Agric. prat. et d'écon. rur, pour le midi de la France, Sept.).

Megnin. - Sur l'affection typhoïde du cheval. C. R, Ac. des Sc., t. LXII, p. 1005.

Pasteur. - Etude sur le vin. Paris.

Pastedr. - Nouv, étude expér. sur la maladie des vers à soie. C. R. Ac. des Sc. t. LXII.

Scaweninger. - De l'effet produit par des substances sur l'organisme. Munich.

TrGri. - Nouvelles recherches sur les maladies charactérisées par la présence des Bactéridies. C. R. Ac. des Sc. t. LXII, p. 294.

1867. De Ranse. - Du rôle des microzoaires et des microphytes dans la genèse, l'évolution et la propagation des maladies. Gaz. méd. de Par. XXII, 6250, 671, 713; 1868, XXIII, 597, 625, 679; 1869, XXIV, 81, 153, 577,673 .

Donnt. - Expérience relative aux générations des animalcules infusoires, t. LXIV.

LüDers. - Ueber Abstammung und Entwickelung des Bacterium Termo, Duj. Arch. f. mikr. Anat., Bonn, III, 317-344.

Muller L. - Etude sur le poison patride comme cause de maladie et de mort. Munich.

Onimus. - Expérience sur la genèse des leucocytes et sur la génération spontanée. In Jour. de l'Anat. et de la Phys. de M. Ch. Robin, p. 47.

Ch. Robin. - Leçons sur les humeurs. Paris.

A. Schmizz. - Sur la question du poison putride. In Dissert. Inaug. Dorpat.

TIGRI. - Cryptog. rameux trouvé dans les exsudats. C. R. Ac. des Sc.

Van Tieghem. - Recher. pour servir à l'histoire des 
Mucédinées. Fermentation gallique. Ann. des Sc. nat. Bot. $5^{\mathrm{B}}$ série, t. VIII.

1867. Weidenaatm. - Etudes expér. sur l'isolement du poison putride. In Diss. inaug. Dorpat.

1868. Crivelti and MagGr. - Morfologia: Sulla Produzione del Bacterium termo, Duj., e del Vibrio bacillus, Duj. R. Ist. Lomb. di sc. e lett. Rendic., Milano, I, 288-303, 399-406 ; 1869, II, 1208-1212.

C. Davatne. - Art. Bactérie. Dict. encyclopédique des Sc. méd.

Keber. 一 Organismes de la lymphe vaccinale. Dantzick. De Seynes. - Des rapports des Mycodermes et des levûres. Bull. Soc. Bot. Fr. t. XV.

De Seynes. - Sur le Mycoderma vini. C. R. Ac. des Sc.

1869. Béchamp. - Faits pour servir à l'histoire de l'origine des bactéries. Montpel. méd., XXII, 320-325.

Hofmuann. - Mémoire sur les Bactéries. Ann. des Sc. nat. bot. $5^{\natural}$ Série, t. XI. et Botanische Zeitung. Av. et Mai.

De Ranse. - Du rôle des Microzoaires dans les maladies. In Gaz. Méd.

A. Sснмidт. - Recherche sur la sepsine. In Dissert. Inaug.

De Seynes. - Note sur les Mycodermes de l'urine des diabétiques. Journ. de l'Anat. et Phys. norm., etc. t. VI. p. 67.

1870. Brilings et Curtis. - Disease of Cattle in the United States. Am. Journ. of Med. Sciences. Oct.

Le LoRTET. - Végétanx parasites et les nouvelles recherches sur les maladies virulentes et contagieuses. Ann. Dermat. t. II. p. 29.

E. Martцot. - Congrès séricicoles internationaux tenus à Goritz et à Undine en 1870 et 1871.

Max Reess. - Botan. Untersuch. über die alkoolgärungspilze. Leipzig.

Schroeter. - Ueber einige durch Bacterien gebildete Pigmente. Beitr. z. Biol. d. Pflanz. 1, 2, Heft 109-126. 
1870. De Sernes. - Expér. Physiologiq. sur le Penicillium glaucum. Soc. Philom. 9 av.

De Sernes. - Note sur le Pencillium bicolor. Ann. Sc. nat. t. XIV. C. R. Ac. des Sc.

1871. Bcrdon-Sanderson. - Origin and Distribution of the Microzymes in Water and in the Tissues and Liquids of the Organism. Journ. of Mic. Science, Oct.

Jeannel. - Dict. de méd. et de chirur. pratiques. Paris, t. XIV, article Ferment.

Manassein. - Ueber die Beziehungen der Bacterien zum Penicillium glaucum L. K. und über den Einfluss einiger Stoffe auf die Eutwickelung dieses letzteren. Centralbl. f. p. med. Wissensch. IX, 177-180.

Oertel. - Experimental Researches upon Diphtheria. Deuts. Arch. f. Klin. Med.

OrTH. - Présence du Microsporon septicum dans les fièvres.

Ch. Robin. - Du microscope et des injections. Paris. Strums. - Rep. of Metr. Board of Health of New York.

In Brit. and For. Med. Chirurg. Rev. April.

Tiegel. - Corresp. Blatt. für chirurg. Aertze.

Tiegel. - Discussion sur l'infection purulente. Ac. Méd. Mars, Oct.

Tiegel. - Propriétés du Microsporon septicum. In Diss. Berne.

WALDYer. - Bericht der medizin Sect. der Schles. Gesell.

WALDYER. - Ueber das Vorkommen von Bacterien bei der diphtheritischen Form des Puerperalfiebers. Arch. f. Gynack. III, 293-297.

1872. Bollinger. - Sur la pathologie du sang de rate. Munich.

Bollinger. - Médecine Centralb. 29 juin.

H. DE Brehm. - Sur la mycose septique. In Diss. inaug. Dorpat. 1872.

Cavafy. - On the Effect produced on the Capillary Circulation by the Injection of Putrid Blood into the Lymphatic System. St. George's Hospt. Rep. VII, 1872-1875, p. 17. 
1872. CонN. - Untersuch. über Bakterien. Beiträge zur Biologie der Pflanzen, Bd. 1 Heft 2, p. 127.

Eвerth. - Zur Kentniss der bacteritschen Mykosen. $4^{\circ}$. Leipzig.

Engel. - Les ferments alcooliques. Thèse Fac. des Sc. de Paris, no. 336.

GaRner. - Experimental Observations on the Appearance of the Lower Forms of Life. Lancet, Lond. I, 789,824 .

KLEBs. - Sur l'anatomie path. des blessures par armes de guerre. Leipzig.

Kreis. - Ueber Sarcina und Bacterienfrage. Allg. wien. med. Ztg., XVII, 51, 59.

LEX. - Ueber Fermentwirkungen der Bacterien. Centralbl. f. d. med. Wissensch. X, 291, 305, 513.

Pasterr. - Note sur la product. de l'alcool des fruits. C. R. Ac. des Sc.

Pasteur. - Faits nouveaux pour servir à la connaissance de la théorie des fermentations proprement dites. C. R. Ac. des Sc., t. LXV.

Pode and Lankester. - Experiments on the Development of Bacteria in Organic Infusions. Proc. Roy. Soc. Lond. 1872-1873, XXI, 349-358.

Poporf. - Action de la levûre de bière et d'autres organismes microscopiques sur les animaux. In Berlin Med. Wochensch.

Rawitsch. - Sur la question de l'infection putride et ses rapports avec l'anthrax malin. Berlin.

J. Schroeter. - Über einige durch Bacterien gebildete Pigmente. Beiträge zur Biologie der Pflanzen, t. II. Heft 2, p. 109-125.

Senator. - Sur la dipththérie. In Archiv. f. path. Anat. u. Phys. t. LVI.

De Sernes. - Sur les transformations des Bactéries et des Mucédinées en Levûres alcooliques. C. R. Ac. des Sc., Janv.

STEndener. - Organismes végétaux producteurs des maladies. In Wolkmanns sämmt. Klin. Vortr.

$Z_{\mathrm{AHN}}$ - - Sur l'inflammation et la production des abcès. In Diss. inaug. 
1873. Bastian. - Proc. Royal Soc.

Baxter. - The Action of the Cinchona Alkaloids and some of their Congeners on Bacteria and colorless Blood-corpuscles. Practitioner, Lond. XI. 321-351.

Béhier et Liouville. - Expériences sur la septicémie. In Gaz. Méd.

Brrsch-Hirschfeld. - Researches upon Pyemia. Archiv der Heilkunde.

Birsch-Hirschfeld. - Die Bacterien im Blut Pyämischer. Centralbl. f. d. med. Wissench. XI, 609-612.

Bochefontaine. - Note sui quelques expériences relatives à l'action de la quinine sur les vibrioniens et sur les mouvements amiboïdes. Arch. de physiol. norm. et path., Par. V, 389, 724.

Bodley. - Communication sur la Septicémie. In Bull. Acad. méd., Janvier.

Chavdeau. - Phénomènes de mortification sur l'animal vivant. C. R. Ac. des Sc.

Clémentr. - Exp. Researches upon the Presence of Bacteria in the Blood of Septicemic Rabbits. Centralblatt.

CoLIn. - Nouvelles recherches sur l'action des maladies putrides et sur la septicémie. Bull. de l'Acad. de Méd.

Von Collmann. - Bakterien im Organismus eines an einer grossen Verletzung am Oberschenkel verstorbenen zwanzigjährigen Mädchens. $8^{\circ}$. Göttingen.

Davaine. - Action de la chaleur sur le virus charbonneux. C. R. Ac. des Sc., Sept.

Davaine. - Action des substances antiseptiques sur le virus charbonneaux. C. R. Ac. des Sc., Oct.

Dolchensкow. - Inoculation des substances putrides dans la cornée des lapins. Centralblatt.

J. Duval. - Mém. sur la mutabilité des germes microscopiques et la question des ferments. Journal d'An. et Phys. de Ch. Robin, t. IX.

Eberth. - The Diphtheritic Processes. Centralblatt.

Ebersh. - Mycosis of Wounds in Frogs and its Consequences. Centralblatt.

ENGLE. - Upon the Spirillum of Obermeier. Klin. Wochensch. 
1873. Carl Frnck. - Upon Pyemia and Septicimia. Bayer. ärztl. Intel.

Herberg. - The Puerperal and Pyemic Processes. Vogel, Leipzig.

KLeBs. - Contribution to the Study of Micrococcus. Archiv. f. exper. Pathol., vol. I.

Kostarev. - Sposob izucheniya doizheniya bakterii. Laitop. Kirurg. Obsch. $\nabla$ Mosk., 1873-1875, I. 199210.

Kussner. - Upon the Question of Bacteria. Centralblatt.

LABORDE. - Recherches sur la septicémie expérimentale. Soc. de Biol.

Laura. - L'uomo, i microfiti, ed i microzoi. Gior. d. r. Accad. di med. di Torino, XIII, 161-180.

Lister. - A further Cuntribution to the Natural His tory of Bacteria and the Germ Theory of Fermenta tive Changes. Quart. J. Micr. sc., Lond., XIII, 380$408,3 \mathrm{pl}$.

Litten. - L'épidémie de fièvre récurrente à Breslau en 1872 et 1873.

Lugins ÜHL. - The Micrococcus of Variola. Verhandl. d. physik. med. Gesel.

Lокомькі. - Researches upon Erysipelas. Arch. f. path. und phys., t. LX.

Markiewicz. - Micrococcus i. bakteryje; kilka slów o pasoźytach roślinnych, o ich zuaczenin botaniczném i patologiczném. Medycyna, Warszawa, I, 693, 709, 725, 741,757 .

Obermeier. - Filament trés-fin et mobile dans le sang d'un malade atteint de fièvre récurrente. Centralblatt.

OǴe. - Fatal Epidemic (Typhoid) Disease among Fish, whose Blood during Life contained Bacteria. Lancet, London II, 657.

Onrmes. - Sur l'infection putrine. Ac. de méd., 11 Mars.

Onımus. - Sur la septicémie. Bull. Ac. de méd., 15 Avril et 9 Sept. 
1873. ORтн. - Researches upon Puerperal Fever. Archiv. f. path. Anat. und phys.

OrTh. - Researches upon Erysipelas. Arch. f. exp. path. und phar. t. I.

Osler and Schäfer. - Ueber einige in Blute vorhandene Bacterien-bildende Massen. Centralbl. f. d. med. Wissensch., XI, 577 .

Place. - Over den invlod van hoogere warmtegraden op het leven van bacteriën. Werk. v. h. Genootsch. t. Bevord. d. Nat. Genees. en Heelk. te Amst., III, 126.

Ray-Lankester. - On a Peach-colored Bacterium (B. rubescens). Quar. J. of mic. Sc., t. XIII.

Raynaud. - Inoculabilité du sang dans un cas de pyohémie spontanée. Gaz. hebdom. de méd. et chir.

Raynadd. - De la nature de l'érysipèle. Union médicale.

ReIss. - Upon the Micrococcus. Centralblatt.

Samuec.-Action of Putrefactive Processes upon the Living Organism. Arch. f. exper. pathol. und pharm., t. I.

Trorsier. - Etude du sang de l'érysipèle. Bull. Soc. Anat. t. VIII.

Volpian. - Sur la septicémie. Gaz. méd.

Weissenberg. — Recurrent Fever in Children. Jahrb. f. Kinderheilk.

Wiegert. - Upon the Spirillum of Obermeier. Klin. Wochens.

Wolff. - Injection of Microscopic Organisms. Centralblatt.

1874. E. Baltus. - Théorie du microzyma: De la naissance et du rôle du leucocyte du pus et de la Bactérie. Montpellier médical, oct. et nov. 1874.

Bechamp. - Sur les microzymas de l'urine. Montpellier médical.

BÉchamp. - Discussion sur les urines ammoniacales. Bull. Ac. de méd., 20 jan.

Bencke. - Bau, Lebensweise und Entwickelung der menschlichen Eingeweidewürmer. Schrift. d. phys. Oekonom. Gesellsch, zu Königsb., XV, 13. 
1874. Bennet. - Pyemia. Brit. Med. Journ.

Billroth. - Untersuchungen über die Vegetationsformen von Coccobacteria septica.... Berlin.

Oscar Brefeld. - Botanische Untersuch. über Schemmelpilze. Die Entwicklungsgeschichte von Penicillium. Leipzig.

Cunningham. - Microscopic Examination of the Air of Calcutta. Rep. to San. Com. with Govt. of India, 1872.

Davaine. - Action des substances antiseptiques sur le virus de la septicémie. Soc. de Biologie.

Demarquay. - Sur le pansement des plaies avec l'acide phénique suivant le procédé de Lister et sur le développement des vibrioniens dans les plaies. C. R. Ac. de Se.

Demarquay. - La septicémie et la pyohémie. Gaz. Méd.

Dumas. - Sur la ferment. alcool. Ann. de Chim. et Phys., t. III.

Eberth. - The Bacteria of Perspiration. Arch. f. path. anat. u. phys., t. LXII.

V. Feltz. - Note sur la septicémie expérimentale. C. R. Ac. des Sc., 30 nov. 1875.

Feltz et Ritter. - Etude sur l'alkalinité des urines et sur l'ammoniémie. Jour. de l'anat. et physiol.

Frankel et Orth. - Two Cases of Charbon in Man. Berlin Klin. Wochens.

A. Frisch. - Etudes expérimentales sur la propogation des organismes de la putréfaction dans les tissus et sur les phénomènes inflammatoires provoqués par l'inoculation du liquide contenant des ferments.

Frisch. - Etudes expér. sur la reproduction dans les tissus des organismes de la putréfaction. Erlangen.

Gosselin et Robin. - Recherches sur l'urine ammoniacale. C. R. Ac. des Sc.

Greenfreld. - Histology of Diphtheria. Brit. Med. Journ.

Gobler. - Fermentation ammoniacale de l'urine. C. R. Ac. des Sc. 
1874. Ha eckel. - Histoire de la création. Paris.

Henrot. - Théorie et traitement de certaines formes d'infection purulente et de septicémie. Reims.

Arnold Hiller. - Der Antheil des Bacteries am Fäulnissprocess im besondere der Harnfäulniss. Centralblatt.

Hiller. - The Inflammatory Process in Erysipelas. Berlin klin. Wochensch.

Hiller. - Bacteria and Suppuration. Centralblatt f. Chirurgie.

KaPOSI. - Ueber den gegenwärtigen Stand der Lehre von der ätiologischen Beziehung kleinster Organismen (Micrococcus) zu den Infectionskrankheiten. $8^{\circ}$ Wien. Kenrer. - Sur l'empoisonnement putride. Arch. f. exper. Path.

LALlier. - Sur la fermentation ammoniacale de l'urine. C. R. Ac. des Sc.

Lanzi. - Upon the Origin and Nature of the Bacteria. Rome.

LANDAD. - Zur Aetiologie der Wundkrankheiten, etc. Verhandl. d. deutsch. Gesellsch. f. Chir., II, 193-220.

Letzerich. - Microscopic Reactions of the Fungus of Diphtheria. Berlin klin. Wochensch.

Letzerich. - Diphtheria Local and General. Arch. f. path. Anat. u. Phys., t. LXI.

Martini. - Beobachtungen über Micrococcenembolien innerer Organe und die Veränderungen der Gefässwand durch dieselben. Verhandl. d. deutsch. Gesellsch. f. Chir. II, 99-105.

MAYer. - Manuel of the Chemistry of Fermentations. Heidelberg.

OrTH. - Ueber die Form der pathogenen Bacterien. Arch. f. path. Anat., etc., LIX, 532-538.

Panum. - The Putrid Poisons, the Bacteria, Putrid Intoxication and Septicemia. Arch. f. path. Anat. u. Phys., t. IX.

Pissin. - Histology of Vaccinia. Berlin klin. Wochensch.

Ponfick. - Abnormal Cells in the Blood of Recurrent Fever. Centralblatt. 
1874. H. R. RANKE. - Die Bacterien vegetation unter dem Listerschen Verbande. Centralb. f. Chirurgie, no. 13. Reimschneider. - Ueber den Einfluss der putriden Intoxication auf den Blutdruck. Dissert. inaug. Dorpat. Centralb. f. Chirurgie, no. 39.

H. Servel. - Sur la naissance et l'érolution des Bactéries dans les tissus organiques mis à l'abri du contact de l'air. C. R. Ac. des Sc.

Carl Stropp. - Vaccination und Micrococcus. Berlin. TIEGEL. - Cocicobacteria septica in the Healthy Body of Vertebrate Animals. Arch. f. path. Anat. u. Phys., t. LX.

Thoresen. - Erysipelas. Nordiskt Med. Archiv., t. VI.

Moritz Traube und Gschleiden. - Ueber Fäulniss und den Widerstand der lebenden Organismen gegen dieselbe. Berlin klin. Wochens. No. 37.

Aug. Vogel (de Prague). - Rôle of the Inferior Organisms in Infectious Maladies. Arch. für Dermat.

WAGNer. - Intestinal Mycosa and its Relations with Charbon. Arch. der Heilkunde.

WeIgert. - Contributions to the Pathological Anatomy of Variola. Breslau.

Weigert. - Lesions of the Liver, Spleen, etc. Berlin klin. Wochens., no. 44.

Weigert. - Structure of the Variolus Pustule. Berlin klin. Wochens., no. 8.

ZuELRER. - Ueber putride Intoxication. Berlin klin. Wochens. 1864, no. 49.

1875. Bastian. - The Germ Theory of Disease. Brit. Med. Journ.

Bíchaмp. - Sur les Microzymes et les Bactéries. Montpellier médical.

Bergmann. - Le poison putride et l'intoxication putride. Dorpat.

Bergmann. - Upon the Question of Putrid Intoxication. Deutsche Leitschr. f. Chir.

Brrot. - De la nature de la couenne des liquides d'épanchements. Rap. par J. Drivon. Mém. Soc. d. sc. méd. de Ljon. XV. pt. 1, 143-156. 
1875. Booloumute. - Résultat des recherches et observations sur l'existence des micro-organismes dans les suppur'ations, leur influence sur la marche des plaies, et les divers moyeus à opposer à leur développement. Mouv. médical.

Bourdon-Sanderson. - Lectures on the Occurrence of Organic Forms in connection with Contagious and Infectious Diseases. British Med. Journ.

Bucholtz. - Antiseptica und Bakterien. Arch. f. exper. Path. u. Pharmakol., IV, 1-81.

Chauveau. - De l'agent pyohémique. Ass. franç. Congrès de Nantes.

CоHN. - Untersuch. über Bakterien. Beiträge zur Biologie der Pflanzen. Bd. I, heft 3, p. 141.

DahLer J. P.-- On the Chemical Cause of the Transformation of Starch into Sugar, Sugar into Alcohol, and Alcohol into Acetic and Carbonic Acids, under the Influence of Inferior Organisms. Arch. f. Anat. und Phys. f. Pflüger.

Demarquay. - Recherches expérimentales sur l'influence de certaines substances sur le développement des Vibrions. Union Médicale.

Drysdale. - On the Existence of Flagella in Bacterium termo. Monthly Mic. Journ.

Eвerth. - Untersuchungen über Bakterien. Arch. f. path. Anat., etc., LXII, 504-515, 1 pl.

Eidam. - Unters. über Bakterjen. Die Einwirkung verschiedener Temperaturen und des Eintrockenens auf die Entwicklung von Bakterium termo. Beit. z. Biol. d. Pflanzen, Bd. I, Heft 3, p. 208.

V. Feltz. - Rech. expériment. sur le principe toxique. du sang putréfié. C. R. Ac. des Sc.

Gayon U. - Altération spontanée des cufs. Thèse Fac. des Sc. Paris. no. 362.

Hiller. - Ueber diagnostische Mittel und Methoden zur Erkennung von Bakterien. Arch. f. path. Anat. und Phys. t. LXII.

Hiller. - Contribution to the Study of the Nature of Contagia and of Putrefaction. Archiv. f. klin. chir. 
1875. JACoBs. - Granulations et molécules punctiformes de la vaccine. Presse Méd., XXVII.

KLEBS. - Beiträge zur Kentniss der pathogenen Schistomyceten. Arch. f. exper. Path. u. Pharm. 1873, I, 31, 4 pl., 443; 1875, III, 305; IV, 107, 1 pl., 207, 2 pl., 409, 1 pl. ; $1876, \mathrm{~V}, 350$.

KLeIn. - On the Pathology of Sheep-pox. Quar. Journ. of Mic. Sc. n. s. No. LIX, p. 229.

KolAczeK. - Bacterien im normalen Blute. Centralbl. f. Chir., II, 197.

Ĺ́opold LandaU. - Zur Etiologie der Wundkrankheiten nebst Versuchen über die Beziehungen der Fäulniss-Bacterien zu desselben. Archiv. f. klin. Chir. XVII, 4 fasc. p. 527.

Lister. - A Contribution to the Germ Theory of Putrefaction and other Fermentative Changes, and to the Natural History of Torulæ and Bacteria. $4^{\circ}$. Edinburgh.

Merburg. - Du sang de rate. Diss. inaug. Bonn.

Moxon and Goodhart. - Observations on the Presence of Bacteria in the Blood and Inflammatory Products of Septic Fever, and on Cultivation of Septicemia. Guy's Hospital Reports, 1875, t. XX, p. 229.

Nepyed. - Cataplasme bactérifère. De la présence des Bactéries dans les urines d'un malade qui n'a jamais été sondé. Soc. Biol.

Nepveu. - Rôle des organismes infus. dans les lésions chirurg. Gaz. méd.

J. Nuesch. - Die necrobiose in morphologischer Beziehung betrachtet. Schaffouse.

Richardson. - Some New Researches upon the Cause and Origin of Fever from the Action of Septic Poisons. Brit. Med. Journ.

Roвin. - Sur la nature des fermentations en tant que phénomènes nutritifs, désassimilation des plantes. Journ. de l'Anat. et Phys.

Rothe. - Ueber den gegenwärtigen Stand der Bakterienfrage. Memorabilien, Heilbr., XX, 337-357.

Satterthwaite. - Nature of Bacteria and their Relation to Diseases. New York Med. Record. 
1875. Schutzenberger. - Les fermentations. Paris. Siedamgrotzicr. - Des Bactéries du sang de rate. Deutsch. ztschrift. für Thierm. und vergl. Path. t. I. Siedamgrotzkr. - Zur Kentniss der Milzbrandbakterien. Deutsche Ztschr. f. Thiermed., I, 253-259.

Strmson. - Bacteria and their Influence upon the Origin and Development of Septic Complications of Wouuds. N. York M. J., XXII, 113-145.

1876. AddDERs. - Die giftige Wirkung der durch Bakterienvegetation getrübten Pasteur'schen Nährflüssigkeit. Deutsche Ztschr. f. Chir., VII, 1-35.

BALOGH. - Sphärobacterien in der entzündeten Hornhaut. Centralbl. f. d. med. Wissensch., XIV, 99-101. Balogh. - A gasser-dúcz és szemgyuladás. Orvosi hetil., Budapest, 1, 21, 45.

BaLogH. - Bacteriumok a növénysejtek képzö-anyagában. Ibid. 185, 205, 225-245.

Bastian. - Upon the Conditions which favor Fermentation and the Appearance of Bacilli and Micrococci in Liquid previously boiled. Journ. of the Linn. Soc. Zool. XIV.

BeLL. - An Account of the Recent Researches into the History of the Bacteria, made by and under the Direction of Prof. Cohn. Quart. J. Micr. Sc., Lond. XVI, $259-278,1 \mathrm{pl}$.

Padr Bert. - Expériences sur la Bactéridie. Soc. de Biologie.

Bollinger. - Ueber die Bedeutung der Milzbrandbakterien. Deutsche Ztschr. f. Thiermed., II, 341-350.

Botchardat. - Virus nosocomial, pansement ouaté, pansement de Lister. Bull. gén. thérap., t. LXIII, p. 433.

Boulax. - Cas présumé de spontanéité de fièvre aphtheuse chez une vache. Recueil de médec. vétér., p. 349 .

Bovley. - La question du charbon. Recueil de méd. vétér.

Boulex. - Da charbon. In Rec. de méd. vétér.

Bбcholtz. - Ueber das Verhalten von Bakterien zu einigen Antisepticis. $8^{\circ}$. Dorpat. 
1876. Burdon-Sanderson. - New Experiments upon the Destruction of the Virus of Putrid Liquids by Filtration through Cylinders of Clay. Wiener medizinische Jahrbucher, heft III.

Burdon-Sanderson. - Atmospheric Germs. Roy. Soc. of London.

Conn. - Unters. über Bakterien. Beit. zur Biol. der Pflanzen, Bd. II, Heft 2, p. 249.

Fichter. - Of the Fungi regarded as Causes of Infectious Diseases. Soc. méd. de Bâle, séance du 5 oct. Blatt für schweiz. Aertze, no. 21.

Fremy. - Génération des ferments.

A. Guilladd. - Les ferments figurés. Thèse de concours. Paris.

HARz. - Zur Kentniss der sogenannten Milzbrandbacterien. Centralbl. f. d. med. Wissensch., XIV, 277.

Hadssmann. - Ueber das primäre Vorkommen von Bakterien in einem geschlossenen menschlichen Ei. Arch. f. path. Anat., etc., LXVII, 11.

L. Heidenreich. - Ueber die Schraubenbacterie des Rüchfallstyphus. Petersb. med. Wochensch. 1876.

G. HuFner. - Ueber eine neue einfache Versuchforme zur Entscheidung der Frage, ob sich niedere Organismen bei Abwesenheit von gasförmigen Sauerstoffe entwickeln können. Journal für praktische Chemie, Bd. XII.

Jorr. - Etudes sur l'épizootie encore régnante chez les vers à soie du mûrier. Etat actuel de la question. Extr. du Journ. d'agric. etc. pour le Midi de la France. mai et juin 1876 .

Kосн. - Die Etiologie der Milzbrand-Krankheit, begründet auf die Entwick. des Bacillus anthracis, Beiträge zur Biol. der Pflanzen, Bd. II, Heft 2, p. 277.

Maclagan. - The Germ Theory applied to the Fxplanation of the Phenomena of Disease.

Martin. - Recherches sur la structure et le développement des Bactériens et Vibrioniens. Soc. Biol.

Moscclos. - Examen du mucus coagulé par l'alcool fort et desséché. Journ. de Ch. et Pharm. 
1876. Pasteur. - Etude sur la bière.

Ponfiok. - Etudes anatomiques sur le typhus récurrent. Archiv. f. path., Anat. und Phys. t. LX.

C. F. Salomonsen. - Bot. Zeit. no. 39.

Trndall. - Putrefaction and Contagion in Relation to the Optical State of the Atmosphere. Revue scient.

Eng. Warming. - Om nogle ved Danimarks Kyster lavende Bakterier. Copenhagen.

Waldexer. - Upon the Phenomena of the Development of Animal Organisms. Berlin klin. Wochens., no. 50.

1877. Buchiolitsa. - Kvvoprosu o pitanii bakterii. Voyennomed. J., St. Petersb. CXXIX, pt. 2, 267-288.

Bбсноцтz. - Ein Beitrag zur Kentniss der Ernährungsverhältnisse von Bakterien. Arch. f. exper. Path., etc., Leipz., VII, 81-100.

Bucholiz. - Untersuchungen über den Einfluss der Temperatur auf Bakterienvegetation. Arch. f. exper. Path. etc. Leipz. IV, 159-167.

Chénirr. - Sur la genèse des maladies virulentes et de la morve en particulier. Rec. de méd. vétér.

Darreau. - Cas présumé de spontanéité de maladie charbonneuse. Rec. de méd. vétér.

Dallinger. - Researches into the Origin and Development of Minute and Lowly Life-forms, with a Glance at the Bearing of these upon the Origin of Bacteria. $8^{\circ}$. London.

Davarne. - Observations relatives aux expériences de M. Paul Bert, sur la maladie charbonneuse. Rec. de méd. vétér.

Delamotte. - Spontanéité de la morve et du farcin. Rec. de méd. vétér.

DucladX. - Production d'acides gras pendant la ferment. alcool. Ann. de l'Ecole normale, t. II.

Ferrand. - Le rôle de la Bactéridie dans le charbon. France médicale, p. 666 .

Frisch. - Ueber den Einfluss niederer Temperaturen auf die Lebensfähigkeit der Bacterien. Sitzungsb. d. k. Akad. d. Wissensch., Wien, LXXV, 257-269. 
1877. Gerber und Birsch-Hirschfeld. - Ueber einen Fall von Endocarditis ulcerosa und das Vorkommen von Bakterien in dieser Krankheit. Arch. der Heilk. t. XVII. p. 208.

Padl Grawitz. - Beiträge zur systematischen Botanik der Pflanzichen Parisiten mit experimentallen Untersuchungen über die durch sie bedingten Krankheiten. Virchow's Archiv. für path. Anat.

KLEBS. - Note sur le charbon. Rec. méd. vétér. no. du 15 nov.

KоcH. - Verfahren zur Untersuchung zum conserviren und photographiren der Bacterien. Beiträge zur Biologie der Pflanzen, t. II.

KocH. - Researches upon Charbon. Berlin Wochenschrift, nos. 18 and 19.

Koster. - Het vraagstuk der specifieke bacteriën. Nederl. Tijdschr. v. Geneesk., Amst., XIII, 1, Afd., 457472.

De Lanessan. - Art. Bactériens, Dict. de Baillon.

L. Lemaitre. - Mémoire sur le typhus contagieux. Rec. de méd. vétér.

Létifivant. - Du pansement de Lister. Ass. Française pour l'avancement des Sc. VIme sess. au Havre.

LEx. - Ueber die Ernährung und den Stoffwechsel der Backterien. Deutsche med. Wochenschr., Berl., III, 449,465 .

LIsTER. - The Lactic Fermentation and its Relations with Pathology. Med. Times and Gaz. 22d Dec.

Livon. - Injection de Bactéridies dans le sang, sans aucun phénomène d'intoxication. Soc. Biologie.

Miquel. - Recherches sur les Bactéries aériennes faites à l'observatoire de Montsouris. Soc. française d'hygiène.

Moоснот. - Charbon sporadique. Rec. de méd. vétér.

NaEgerr. - Die niederen Pilze in ihren Bezeihungen zu den Infectionskrankheiten und der Gesundheitspflege. Munich.

Orth. - Ueber die Schizomyceten und ibre Beziehungen zu Krankheiten. Arch. f. wissensch. u. prakt. Thier., Berl., III, 1-32. 
1877. Pasteur et Joubert. - Sur les germes des Bactéries en suspension dans l'atmosphère et dans les eaux. C. R. Ac. des Sc.

Pukr. - Eves és micrococcusfertözesekkeltett kisérletek. Orvosi hetil., Budapest, XXI, 178, 202, 225, 282, 303. Puky. - Versuche über septische und mikrococcische Infection. Arch. f. path. Anat., etc. Berl. LXIX, $329 \sim 349$.

Sanderson. - The Germinal Particles of Bacteria. Med. Press and Circ., Lond., XXIII, 485.

Schloesing. - Nitrification par les ferments organisés. Journ. de Chim. et Phar. Mai 1877, t. XXV.

E. Semmer. - Zur Genesis der septischen Blutzersetzungen (nach einen Referat in der Allgem. Med. Central Zeitung, no. 54 und 57).

Trndall. - La fermentation et les phénomènes morbides (conf. scientifique de Glasgow). Rév. scientifique, 17 fév. t. VI.

Trndall. - A Combat with an Infective Atmosphere. Pop. Sc. Month. N. Y. X. 641-654.

VAN Treghem. - Sur le Bacillus amylobacter et son rôle dans la putréfaction des tissus végétaux. Bull. Soc. Bot. Fr. XXIV.

1878. Bastian. - Bearing of Experimental Evidence on Germ Theory of Disease. Brit. Med. Journ. 1878, vol. I. p. 49.

Padr Bert. - Anaérobies. C. R. Ac. des Sc.

Buchner, H. - On the Experimental Production of Cattle-distemper Contagion from the Hay Fungi. SB. K. Bay. Akad. Wiss. 1880, pp. 368-413.

Buohner, H. - Experiments on the Origin of the Cattledistemper by Inspiration. SB. K. Bay. Akad. Wiss., 1880, pp. 414-23.

Burdon-Sanderson. - Infective Processes of Disease. Brit. Med. Journ. 1878, vol. I. p. 1, 45, 119, 179.

Chauveat, A. - The Causes which may produce a Variation in the Results of Anthracic Inoculation of Algerian Sheep. Comptes Rendus XC, pp. 1526-1330. Chiene and Ewart. - Do Bacteria or their Germs ex- 
ist in the Organs of Healthy Living Animals? J. Anat. and Physiol. Lond. XII, 448-453.

1878. Cienkowski. - Zur morphologie der Bacterien. Mem. Imp. Acad. of Sci., St. Petersburg.

Colin. - Sur le développement successif de foyers virulents pendant la période d'incubation des maladies charbonneuses. Bull. de l'Acad. de Méd. $2^{\mathrm{e}}$ série, t. VII. p. 199 .

Colin. - La haute température de certains animaux estelle un obstacle au développement des affections charbonneuses. Bull. de l'Acad. de Méd., $2^{\text {e }}$ série, t. VII. p. 496.

Crooke. - Bacteria in Pyæmic Blood. Guy's Hosp. Gaz., Lond. III, 77.

DALLINGER. - On the Measurement of the Diameter of the Flagella of Bacterium termo. J. Roy. Mic. Soc., Lond. I, 169-175, 2 pl.

Dow dsdell. - On Atmospheric Bacteria. Quar. Jour. of Mic. Sci., Jan. 1878.

EWart. - On the Life History of Bacillus Anthracis. Quart. J. Micr. Sc., Lond., XVIII, 161-170, 1 pl.

Frisch (G.). - Verfahren zur Untersuchung zum Conserviren und Photographiren der Bacterien. Ztschr. f. Mikr., I, 119-122.

Arm. Gadtier. - Sur une maladie non encore décrite des vins du midi de la France, dit vins tournés. C. $R$. Ac. des Sc.

Greenfied. - Bacterium Anthracis. (Report to the Royal Agricultural Society.) Quar. Journ. Micr. Sci. XX, pp. 374-376.

C. Grossmann and Mayerhauser. - Upon the Life of Bacteria in Gases. Arch. für gesammte Phys. von Pflüger, t. XV. p. 245.

GunNing. - Bijdrage tot de experimenteele beantwoording der vraag: bestaater bij de lagere zwammen een anaërobië levensvorm? Versl. d. k. Akad. v. Wetensch. Afd. Natuurk., Amst., XII, 310-324.

Haupt. - Ueber das Tingeren und Präpariren der Bacterien. Ztschr. f. Mikr. Berl. I, 175-179. 
1878. Huberson, G. - The Observatory of Montsonris and the Atmospheric "Dusts." Brebissonia II, pp. 145-147. Kaufranan. - Ueber die Zersetzung des Blutes durch Bacillus subtilis. $8^{\circ}$, Leipzig.

KreIN. - Experimental Contributions to the Etiology of Infectious Diseases. Quar. Journ. Mic. Sci., April 1878.

Lister. - The Nature of Fermentation. Quar. J. of Mic. Sc. vol. XVIII, p. 177.

Mrquel, P. - Further Researches on the Organized "Dusts" of the Atmosphere, 10 figs. Annuaire de l'Observ. de Montsouris for 1880, pp. 386-513.

Miquel, P. - Atmospheric Bacteria. Comptes Rendus XCI, pp. 64-67.

Mrкuliez, - Ueber die Beziehungen des Glycerins zu Coccobacteria septica und zur septischen Infection. Arch. f. klin. Chir. XXII, 253-327.

Mrquel. - Etudes de microscopie atmosphérique. Acad. des Sciences, 24 juin.

Muntz. - Recherches sur la fermentation intracellulaire des végétaux. Anu. de Chim. et de Phys. t. XIII. p. 543 .

G. Nepred. - Des bactériens et de leur rôle pathogénique. Revue des sciences méd. de Hayem, t. XI.

Pasteur, Joubert, et Chamberland. - La théorie des germes et ses applications à la médecine et à la chirurgie. C. R. Ac. des Sc. t. LXXXVI.

Pasteur, Joubert, et Chamberland. - Sur le charbon de poules. C. R. Ac. des Sc. t. LXXXVII. p. 47.

Ribeert, H.-A Micro-parasitic Invasion of the whole Cortical Layer of the Brain (Bacteria). Plate X, fig. 5. Arch. Path. Anat. et Physiol. (Virchow) LXXX, pp. 505, 506 .

Schloesing et Hunter. - Recherches sur la nitrification par les ferments organisés. C. R. Ac. des Sc. t. LXXXVI.

Toussaint. - Ferment et diastase. C. R. Ac. des Sc.

Toussannt. - Théorie de l'action des Bactéridies dans le charbon. C. R. Ac. des Sc. 
1878. Totssaint. - Du charbon chez le cheval et le chien; Action phlogogène du sang charbonneux. C. R. Ac. des Sc. t. LXXXVI.

Toussaint. - Sur une maladie à forme charbonneuse causée par un nouveau vibrion aérobic. C. R. Ac. des Sc. t. LXXXVIJ. p. 69.

VALLin. - Sur la résistance des bactéries à la chaleur. Ann. d'hyg. Par., XLIX, 259-267.

WARrington. - Note sur, la nitrification. Ann. de Chim. et de Phys. t. XIV. p. 576.

1879. BACCHI. - Sur l'action du phénate de sonde chez les grenouilles atteintes d'affection bactériémique. C. R. Ac. des Sc., LXXXVIII, 1210.

Bastran. - Organisms in the Blood and the Germ Theory. (Review of Lewis's Microscopic Organisms, etc.) Nature XX, No. 498.

Bert, P. - Experiments on the Blood of Anthrax. C. R. Soc. Biol. Paris XXIX, pp. 19, 20.

Bert, P. - On the Virus of Anthrax, same, p. 24.

Bert, P. - On the Nature of Anthrax, same, p. 317.

Berthelot. - Reply to M. Pasteur. Observations on his Second and Third Reply (on Alcoholic Fermentation). C. R. Ac. des Sc. LXXXVIII, nos. 1, 3, and 5. Brifeld. - Studies on the Schizomycètes. Journal de Micrographie, Vol. II. No. 9.

Butin. - On the Nature of the Fur on the Tongue (4 plates). Proc. Roy. Soc. XXVIII, pp. 484-9.

Crenkowski. - Bacteria as the Cause of the Ropy Change of Beetroot Sugar. (Abstr. by Prof. Lankester.) Quar. Journ. Micr. Sci. XIX, no. 73.

Cours. - Nouvelles recherches, etc. Bull. de l'Acad. de

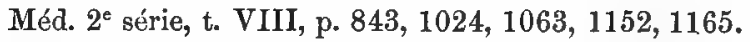
Cons und Mendelsohr. - Ueber Einwirkung des electrischen Stromes auf die Vermehrung von Bacterien. Beiträge zur Biologie der Pflanzen., Bd. III. Heft 1, p. 141.

Dallinger. - Recent Researches into the Origin and Development of Minute and Lowly Forms of Life. Proc. of Roy. Inst. G. B. Vol. VIII, Part 4, No. 67. 
1879. Davarne. - Recherches etc. de la septicémie. Bull. de l'Acad. de Méd. 2e série, t. VIII. p. 121.

Eвerth. - On a New Pathogenic Bacillus. Arch. path. Anat. et Phys. LXXVII. p. 29-34.

Ebertrr. - Ueber einen neuen pathogenen Bacillus. Centralbl. f. d. med. Wissensch. LXXVII, 29-34, 1 pl. ENGel. - On the Production of Conidia by a Bacillus. C. R. Ac. des Sc. LXXXVIII, pp. 976, 977.

FeLz. - Experimental Researches on a Leptothrix found during Life in the Blood of a Woman attacked with severe Puerperal Fever. C. R. Ac. des Sc. LXXXVIII, No. 11.

Friedrich. - Pathogenetic Bacteria in Salt-water Marshes. Med. Rec. N. Y. XVI, 547.

Harz. - A New Micrococcus Form in the Living Animal. (Sep. imp. from 'Zeitshcr. f. Thiermed.') Leipzig, 1879.

KLeIn. - Infections Pneumo-enteritis of the Pig.

Leflaire. - On the Virus of Anthrax. C. R. Soc. Biol. Paris, XXIX, p. 20.

Lewis. - The Microphytes which have been found in the Blood and their Relation to Disease. (1 plate and 18 woodcuts.) Quart. Journ. of Mic. Sci. XIX, pp. 356-404.

LIvoN. - Injections of Bacteria into the Blood without any Phenomena of Poisoning. C. R. Soc. Biol. Paris, XXIX, pp. 355, 350.

Marix. - Des ulcérations intestinales et autres phénomènes morbides déterminés par les injections intraveineuses de levûre de bière. $\quad 4^{\circ}$, Paris.

N̈̈GELr. - Theory of Fermentation. Abh. Bay. Akad. München, XIII, Part 2, pp. 75-205.

Netcki and Giacosa. - Giebt es Bacterien oder deren Kieme in den Organen gesunder lebender Thiere? J. f. prakt. Chem. Leipz., XX, 34-44.

Neucki and Schaffer. - Ueber die chemische Zusammensetzung der Fräulnissbacterien. J.f. prakt. Chem., $\mathrm{XX}, 443-466,1$ pl.

Pasteur. - Observations on the Communication of $\mathbf{M}$. 
Trécul (on Alcoholic Fermentation). Reply to the Notes of M. Trécul of the 30th Dec. and 13th Jan. Observations on his Reply. - Observations on his Last Reply and Further Reply. --Second, Third, and Fourth Replies of M. Berthelot. C. R. Ac. des Sc. LXXXVIII, nos. 2, 3, 4, and 6.

1879. Pasteur. - Observations on M. Felz's Paper. C. R. LXXXVIII, pp. 1216, 1217.

Routier and REgnard. - A Case of Anthrax observed at the Hôtel-Dieu. C. R. Soc. Biol. Paris, XXIX, pp. $442-445,465,466$.

RoвIN. - Remarks on Bacterian Fermentation. Journ. Anat. and Phys. (Robin), XV, p. 465-91.

PragMowsKi. - On the History of Development and Ferment. Action of some Species of Bacteria. Preliminary Communication. Bot. Zeit. XXXVII. p. 409-24. Treghem, Van. - Identity of Bacillus Amylobacter and the Butyric Vibrion of M. Pasteur. C. R. Ac. des Sc. LXXXIX, p. 5.

Tommasi-Crudelli and Klebs. - On the Nature of the Specific Agent which produces Malarial Fever. Trans. R. Acad. Lincei, III. pp. 216-20.

Úricichs. - Ueber Vegetation von Pigment-Bacterien in Verbandstoffen. Arch. f. klin. Chir. Berl., XXIV, 303-308.

Waldstein. - A Contribution to the Biology of the Bacteria. Arch. path. Anat. et Phys. LXXVII, p. 34-68.

WERNich. - Untersuchungen über Bacterien. Beiträge zur Biologie der Pflanzen, Bd. III. Heft 1, p. 105.

Wernion, H. - Action of Dry Heat and of Sulphurous Acid on the Bacteria which accompany Putrefaction. Nature XII. pp. 311, 312 (Abstract from Centralblatt f. die Med. Wiss.).

Wernich, H. - The Aromatic Products of Decomposition in their Influence on the Schizomycètes. Arch. path. Anat. and Phys. LXXVIII. pp. 51-83.

1880. ARndt. - Observations on Spirochate denticola. The Spirochæte of the Mucus of Teeth. Arch. Path. Anat. and Physiol. LXXIX. pp. 76-86. 
1880. Boemlendorf. - Ein Beitrag zur Biologie einiger Schizomyceten. Dorpat, $1880,8^{\circ}$.

Brantlecht. - Algues d'eau douce, leur rôle pathogénique. Ann. d’Hyg. Public, $2^{e}$ série, t. 2, p. 275.

Dalimager. - Series of Experiments to determine the Thermal Death-point of known Monad Germs, etc. Journ. R. Micr. Soc. III, pp. 1-16.

Déclat. - On the Analogies which seem to exist between the Cholera of Fowls and the "Nelavan" or Malady of Sleep. C. R. Ac. des Sc. XC, pp. 1088-1090. Frisch. - On the Behavior of the Bacilli of "Milzbrand" at extremely low Temperatures. S. B. K. Akad. Wiss. (Wien) LXXX (3d sec.), pp. 77-94.

Friedrich. - Pathogenetic Bacteria in Salt-water Marshes. Medical Record, N. Y.

Greenfield. - Bacillus Anthracis. Rep. to Royal Agricultural Society. Quar. Journ. Mic. Sc., No. LXXIX, p. 374.

Hansen, E. C. - Contributions to the Knowledge of Organisms which live in Beer and the Wort of Beer.

1. Researches on the Organisms which at Different Periods of the Year are found in the Air at Carlsberg and Neighborhood, and which develop in Beerwort, I, pp. 49-67.

2. On the Membranes, pp. 67-72.

3. Organisms observed in Beer and Wort, pp. 72-75. Hansen, E. C. - Compte Rendu Trav. Lab. Carlsberg (French Résumé), Oidium lactis, II, pp. 49-75.

HANSEN, E. C. - Red-colored Saccharomyces, pp. 75-80. Hansev, E. C. - On the Influence exercised by the Introduction of Air on the Fermentation of Wort, pp. $81-88$.

HANSEN, E. C. - Hypothesis of Horvath, pp. 88-93. Hansen, E. C. - Mycoderma Aceti, pp. 94-96.

Hansen, G. A. - Bacillus leproe. Studies on the Bacterium of Leprosy. Arch. Biol. (Van Beneden) I, pp. 225-240.

Hansen, G. A. - Bacillus lepra. Arch. path. Anat. et Phys. LXXIX, pp. 32-42. 
1880. Kingertr. - Contributions to the History of Putrefaction. Part I. Journ. Chem. Soc. XXXVH. 1880, pp. 15-22.

KLebs and Tomassi-Crodeltr. - Studies on the Cause of Intermittent Fever and the Nature of Malaria. 5 plates. Arch. expér. Pathol. et Pharmacol. XI. $88 \mathrm{pp}$.

Konert. - Bacillus Anthracis. Zeitsch. Gesammt. Naturw. (Gieble), IV, pp. 884-886.

Lassar, O. - Die Micrococcen der Phosphorescenz. Arch. f. d. Ges. Physiol., Bonn, 1880, XXI, 104-109.

Loomrs. - The Relation of Bacteria to Pyæmia. Med. Gaz. N. Y., VII, 24.

Luerssen, C. - The Schizomycètes and their Rôle in Diseases and Fermentations. Rev. Internat. Sci. V, pp. 242-260.

MrFLet. - Researches on the Bacteria suspended in the Air. Beitr. Biol. Pflanzen III. pp. 119-140.

Miguel. - Poussières organisées de l'atmosphère. Ann. d'Hyg. Public, 2e série, t. 2, pp. 226, 333.

Moss, E. L. - Experiments on Septic Organisms in Living Tissues. Rep. Brit. Ass. Adv. Sci. 49th Meeting, 1879, pp. 416-18.

Nencki, Giacosa. - Existence of Bacteria or their Germs in the Healthy Organs of Animals. Journ. Prakt. Chem. XX, pp. 34-44.

Nencki. - Relation of Oxygen to the Life of the Microzoa. Journ. Prakt. Chem. XIX, pp. 337-358.

Nencki, M. - Contributions to the Life-history of the Schizomycètes. 62 pp. 2 plates and 7 figs. (8vo, Leipsic, 1880.)

Ollive C. - On the Resistance of Barbirine Sheep to Inoculation with Charbon. C. R. Ac. des Sc. LXXXIX, p. 792.

Pasteur. - Observations (verbal) on the Cold which the Bacteridium of Anthrax and other Microscopic Organisms can support without losing their Virulence. C. R. Ac. des Sc. LXXXIX, p. 1015.

Pastedr. - On Virulent Diseases, and particularly that 
popularly called "Choléra des Poules." C. R. Ac. des Sc. XC, pp. 239-248.

1880. Pastedr. - Studies on Fermentation (trans. by F. Faulkner and D. C. Roff). 8vo, London, 1879.

Pasteur. - On the Cholera of Fowls. C. R. Ac. des Sc. XC, pp. 952-958, 1030-1033.

Pastrur. - On the Extension of the Theory of Germs to the Etiology of some Common Diseases. C. R. XC, pp. 1033-1044.

Pragmowskr. - On the Development of some Species of Bacteria and the Fermentation which they cause. (Transl. from "Bot. Zeitung.") Rev. Internat. Sci. IV, pp. 546-554.

Pragmowski. - Researches on the Developmental History and Ferment-action of some Species of Bacteria, 58 pp. 2 plates (8vo., Leipzig, 1880).

RoMdegUtire. - The Microscopic Organisms of the Blood. Rev. Mycol. II, pp. 71-73.

Schuoestrg and Munz. - Researches on Nitrification. C. R. Ac. des Sc. LXXXIX, pp. 891-894, 1074-1077. Sorka, G. - On the Passage of Schizomycètes into the Air. S. B. K. Bayer. Akad. Wiss., München, 1879, pp. 140-147.

StapF, F. M. - Bacteria in the Gothard Tunnel. Zeitschr. Gesammt. Naturw. (Giebel), IV, pp. 848-853. Talmy. - On the Analogies which seem to exist between the Cholera of Fowls and the Malady of Sleep (Nelavan). C. R. Ac. des Sc. XC, pp. 1104-1117.

Tieghem, P. Van. - On the Butyric Ferment in the Coal Epoch. C. R. Ac. des Sc. LXXXIX, pp. 1002-1004. Tieghem, P. Van. - On the pretended Flagella of Bacteria. C. R. Ac. des Sc. LXXXIX, pp. 37-45.

Tieghem, P. Van. - Development of Spirillum Amyliferum. Sp. Nov. C. R. LXXXIX, pp. 65-68.

Tieghem, P. VAN. - On the Spores of some Bacteria. C. R. LXXXIX, pp. 141, 142.

Tieghem, P. VAN. - On the Fermentation of Cellulose. Bull. Soc. Bot. Fr. XXVI, pp. 25-30.

Tommasi-Crudelli, C. - Bacillus Malariæ of Selinunte 
and Campobello. Atti R. Accad. Lincei (Transunt.), IV, pp. 110-113; 653-696.

1880. VALLiN. - Sur la résistance des bactéries à la chaleur. Hun. d'Hyg. Public, $2^{\text {e }}$ série XLIX, p. 259.

Vize, J. E. - The Diphtheria Fungus. Midl. Nat. II, pp. 289-291.

VIZE, J. E. - Micro-fungi Britannici Cents. 1-4.

Waldstein. - Contribution to the Biology of the Bacteria. Quart. Journ. Micr. Sci. XX, pp. 190-201.

Wernich. - Experiments on Infection with Micrococcus prodigiosus, Beit. Biol. rflanz. III, pp. 105-118. 


\section{N D E X.}

\section{A.}

Abscesses, bacteria in, 178 .

Acetic ferment, 83.

Aérobies, 116.

Algae, bacteria classed with, 56 .

Ammonia, does not dissolve bacteria, 53. source of, 149.

Anaérobies, 116.

Antiseptic treatment, in charbon, 166.

Ascococcus, 96 .

A. Billrothi, 96 .

B.

Bacillus, 87.

B. amylobacter, 88 .

B. anthracis, 88 .

B. ruber, 89 .

B. subtilis, 87 .

B. ulna, 89 .

Bactéridie charbonneuse, 88 .

B. des infusions, 90 .

B. du levain, 89.

B. du vin tourné, 90 .

B. glaireuse, 90 .

B. intestinal, 89.

Bacteridium auriantiacum, 73.

B. cyaneum, 73.
B. genus established by Davaine,

18.

B. luteum, 73.

B. prodigiosum, 73 .

B. violaceum, 74.

Bacterio-purpurine, 38 .

Bacterium, 80.

B. æruginosum, 85 .

B. brunneum, 85 .

B. catenula, 82 .

B. grisenm, 81 .

B. lineola, 81 .

B. littoreum, 81 .

B. punctum, 82 .

B. rubescens, 85 .

B. sulphuratum, 86 .

B. syncyanum, 85 .

B. termo, 81.

B. triloculare, 81 .

B. xanthinum, 85 .

Bastian, views and experiments

Beggiatoa, 91 [of, 103.

B. alba, 91 .

B. arachnoidea, 91 .

B. leptomitiformis, 91 .

B. minima, 91.

B. mirabilis, 91 .

B. nivea, 91 .

Billroth, views of, 22.

Blood, bacteria in? 108.

Boracic acid, action of, upon the bacteria, 122. 
C.

Carbolic acid, action of, upon bacteria, 122.

Carbonic acid, action of, upon bacteria, 122.

Carbon, how obtained by bacteria, 113.

Cell-membrane of bacteria, 35 .

Characters, generic and specific, 60.

Charbon, bacteria in, 138.

Chloroform, action of, upon bacteria, 122.

Chlorophyll, bacteria destitute of, 56.

Chromogenes, 72.

Cilia, described by Ehrenberg, 39 . extract from paper of Dallinger and Drysdale describing, 41.

seen by various authors, 39 .

Cladrothrix, 97.

Cl. dichotoma, 97.

Classification of Billroth, 23.

Bory de SaintVincent, 15.

Cohn, 65.

Davaine, 18.

Dujardin, 17.

Ehrenberg, 16.

Hoffmann, 20.

O. F. Müller, 14.

Nägeli, 57.

Sachs, 57.

generic and specific

characters, 59.

Coccobacteria septica of Billroth, 22.

Cohn, classification of, 66 .

Cold, effects of, upon the bacteria, 120.

Color of the bacteria, 31 .

Colored bacteria, where found, 32.

Cornpressed air, action of, upon the bacteria, 121.
Conclusions, 188.

Coze and Feltz, experiments of, 155.

Culture-fluid of Cohn, 113.

Pasteur, 112.

Mayer, 113.

D.

Daliingma and Drysdale, extract from paper of, on "The Existence of Flagella in B. Termo," 41.

Davaine, classification of, 18.

Definition of bacteria, 13 .

Desmobacteria, 86.

Dimensions of the bacteria, 29 .

Diphtheria, bacteria, in, 170.

Dissemination of the bacteria, 103. in air, 103.

in the human organism, 107. in water, 106.

Distinction between animals and vegetables, 53 .

of bacteria from inorganic substances, 49.

Dujardin, classification of, 17.

E.

EHRENBERG, classification of, 16.

F.

FAT-GLOBDLES, resemblance of, to micrococci, 51.

Fermentation acetic, 139.

ammoniacal of urine, 142.

butyric, 145 .

lactic, 144. viscous, 146.

Fermentations, rôle of bacteria in, 137. 
Forms of the bacteria, 29.

Fungi, bacteria classed with, 56 .

G.

Glanders, 171.

Gliabacteria, 45 .

Gliacoccos, 45 .

Grouping, different modes of, 43 .

$\mathrm{H}$.

Heterogenesis, 102.

Hoffmann, memoir of, 20.

I.

INTERMitTent Fever, 174.

K.

KосH, experiments of, relating to charbon, 101.

\section{L.}

Leptothrix, 90.

L. brevissima, 90 .

L. croespitosa, 90.

L. parasitica, 90 .

L. pusilla, 90.

L. radians, 90 .

L. rigidula, 90 .

L. spissa, 90.

Leeuwenhoeck, first to observe bacteria, 14.

Leptothrix, form of grouping of the bacteria, 43.

M.

MaLIgnant PUSTULe, withont bacteria, 164.

Micrococcus, 72.
M. aurantiacus, 73 .

M. bombycis, 76 .

M. candidus, 74 .

M. chlorinus, 73 .

M. crepusculum, 75 .

M. cyanens, 73 .

M. diphtheriticus, 76 .

M. fulvus, 74 .

M. luteus, 73.

M. of epidemic diarrbœa, 77 .

M. of exanthematous typhus, 78 .

M. of glanders, 78 .

M. of intestinal typhus, 78 .

M. of rugeola, 77 .

M. of scarlatina, 77 .

M. of stringy wine, 75 .

M. of syphilis, 78.

M. of the variola of animals, 77 .

M. prodigiosus, 73.

M. septicus, 76 .

M. ureæ, 75 .

M. vaccinæ, 76 .

M. violaceus, 74 .

Microbacteria, 65, 80.

Microsphæra vaccinæ, 76 .

Microsporon septicus, 76 .

Microzyma bomıbycis, 76 .

Miquel, experiments of, 104.

Monas crepusculum, 75.

M. gracilis, 79 .

M. Okenii, 79 .

M. prodigiosa, 73 .

M. termo, 81.

M. vinosa, 79 .

M. Warmingii, 79.

Movement, brownien, 33. canse of, 34 . of two kinds, 32 .

Müller, O. F., classification of, 14.

Multiplication, rapidity of, 125.

Mycoderma aceti, 83, 140.

M. form of, 45 .

M. vini, 141 .

Myconostoc, 96.

M. gregarium, 97. 
N.

N̈̈GELI, classification of, 57 .

Nitrification, rôle of bacteria in, 149.

Nitrogen, how obtained by the bacteria, 112.

Nutrition of the bacteria, 111.

\section{o.}

OpHidomonas sanguinea, 80 .

Origin of the bacteria, 101.

Oxygen, rôle of, 115.

Ozone, action of, upon the bacteria, 121.

\section{P.}

Palmella prodigiosa, 73.

Pathogenes, 75.

Petalobacteria, 46.

Petalococcos, 46.

Pigmentary bacteria, 72.

Place of the bacteria in vegetable series, 55.

Polymorphism, 133.

Position of the bacteria, 48 .

Protoplasm, currents in, 37. granules in, 37 . of the bacteria, 36 .

Pseudobacteria, 50.

Pulverulent precipitate, consisting of bacteria, 46 .

Pus, bacteria in, 111, 177.

Putrefaction, rôle of bacteria in, 148.

R.

RAX-LANKESTER, researches of, relating to bacterio-purpurine, 38.

Relapsing fever, bacteria in, 173.
Respiration of the bacteria, 111 .

Reproduction of the bacteria, 123. by fission, 123. by spores, 126 .

Rhabdomonas rosea, 80 .

Rugeola, bacteria in blood of, 169 .

S.

SACCHAROMYCETES, 57.

Sachs, classification of, 57 .

Sarcina, 96.

Scarlatina, bacteria in blood of, 169.

Schizomycetes, 57.

Schizophytes (Cohn), 66 .

Septicemia, rôle of bacteria in, 152.

Species, physiological of Pasteur, 63.

value of, 61 .

Spherobacteria, 71.

Spirobacteria, 91.

Spiromonas Cohnii, 80.

Spirillum, 94.

S. attenuatum, 96 .

S. Rosenbergii, 96 .

S. rufum, 94 .

S. tenue, 94 .

S. undula, 94.

S. violaceum, 96 .

S. volutans, 94 .

Spirochæte, 93.

S. gigantea, 93 .

S. Olermeieri, 93.

S. plicatilis, 93 .

Sporangia, 130.

Spores, development of, 128.

Starch, in Bacillus amylobacter, 39.

Streptobacteria, 44.

Streptococcos, 44.

Streptothrix, 97.

S. Foersteri, 97. 
Structure of the bacteria, 35 .

Surgical lesions, rôle of bacteria in, 173.

Sulphate of Quinine, action of, upon the bacteria, 122 .

Sulphur, contained in bacteria, 38.

Swarms, 46.

\section{T.}

Tempenature, action of, upon the bacteria, 118.

Thermal death point of bacteria, 119.

Torula form of bacteria, 43 .

Typhoid fever, bacteria in, 171 .

ULGERATIVE ENDOCARDITIS, bar,teria in, 173.

Ulvina aceti, 83.

\section{V.}

VARIOLA, micrococci in, 167.

Vibrio, 92.

V. bacillus, 89 .
V. lactic, 83.

V. lineola, 81 .

$\mathrm{V}$. prolifer, 94 .

V. rugula, 92.

V. serpens, 93 .

V. subtilis, 87 .

V. syncyanus, 85 .

V. synxanthus, 85 .

V. tartaric right, 83 .

V. tremulans, 81 .

Vibrioniens, definition of Ebrenberg, 16.

W.

WoסNDs, effects of bacteria upon, 180.

Y.

YELLOW-FEVER blood, contains no bacteria, 108.

\section{Z.}

ZOOGLGA, genus established by Cohn, 21.

Zooglœa form of grouping of the bacteria, 44 :

Zymogenes, 75. 






1.7.

T.7. 